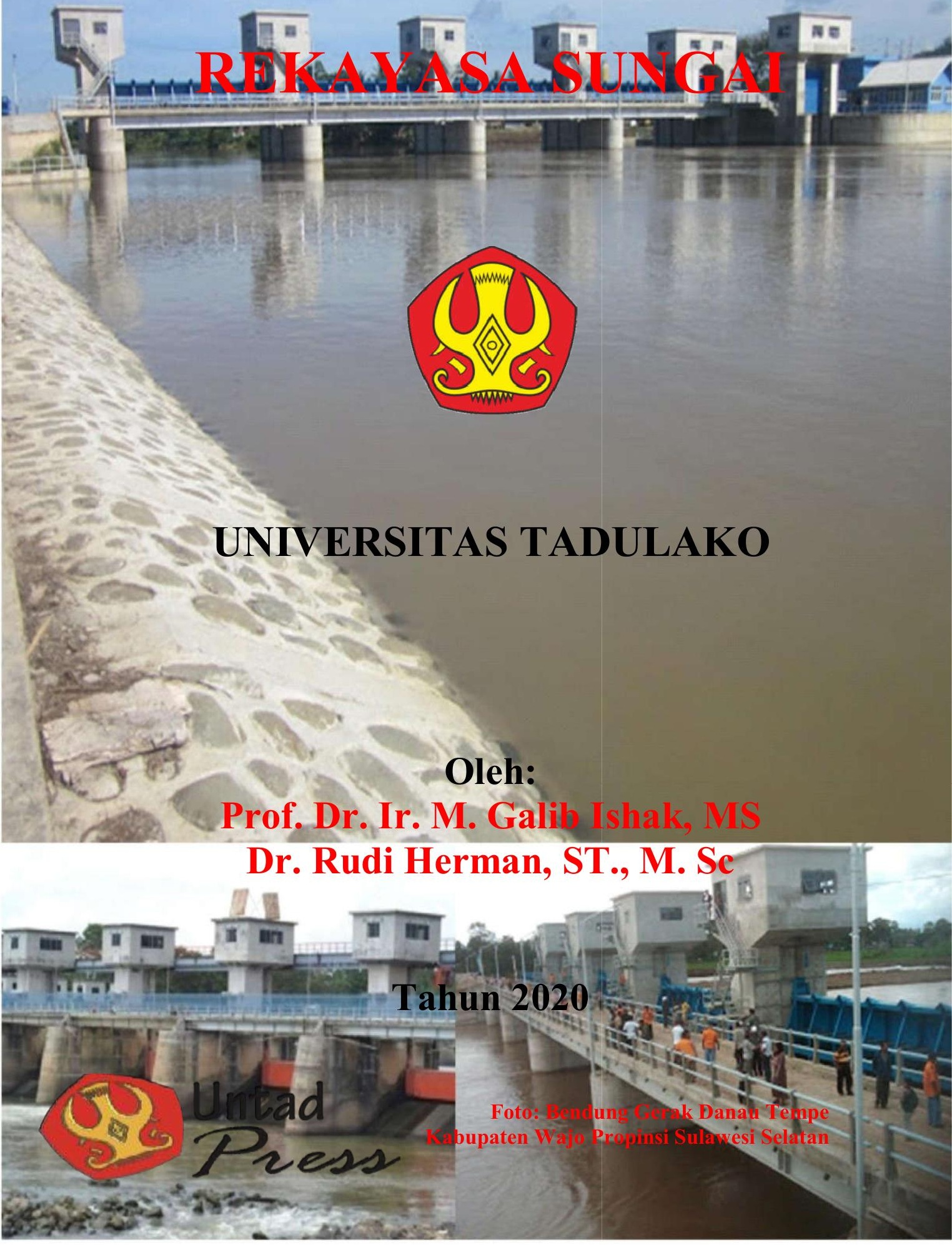




\title{
REKAYASA SUNGAI
}

\author{
Edisi Pertama
}

Oleh:

Prof. Dr. Ir. M. Galib Ishak, MS.

Dr. Rudi Herman, ST., M.Sc.

Penerbit

Untad

Press

2020 


\section{REKAYASA SUNGAI}

M. Galib Ishak Dan Rudi Herman. Palu: Untad Press, 2020 xi hal + 154 hal.; $15,5 \times 23 \mathrm{~cm}$
1. Non Fiksi
i. Judul
ii. M. Galib Ishak

Kutipan Pasal 72:

Sanksi Pelanggaran Undang-Undang Hal Cipta No. 19 Tahun 2002

1. Barangsiapa dengan sengaja dan tanpa hak melakukan perbuatan sebagaimana dimaksud dalam Pasal 2 ayar (1) atau Pasal 49 ayat (1) dan ayat (2) dipidana dengan pidana penjara masing-masing paling singkat 1 (satu) bulan dan/atau denda paling sedikit Rp1.000.000 (satu juta rupiah), atau pidana penjara paling lama 7 (tujuh) tahun dan/atau denda paling banyak Rp5.000.000.000 (lima miliar rupiah)

2. Barangsiapa dengan sengaja menyiarkan, memamerkan, mengedarkan atau menjual kepada umum suatu ciptaan atau barang hasil pelanggaran Hak Cipta atau Hak Terkait sebagaimana dimaksud pada ayat (1) dipidana dengan pidana penjara paling lama 5 (lima) tahun dan/atau denda paling banyak Rp500.000.000 (lima ratus juta rupiah).

ISBN 978-602-6619-82-2

Penerbit:

UNTAD Press

Jl. Soekarno Hatta KM. 9 Palu Sulawesi Tengah 94118

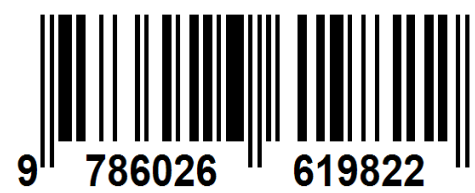




\section{PRAKATA}

Puji dan syukur kehadirat Allah SWT, yang telah melimpahkan Rahmat dan Hidayat-Nya sehingga buku ini yang khusus membahas tentang Rekayasa Sungai dapat terwujud, Penulisan buku ini dimaksudkan dapat menjadi refrensi pada mahasiswa dalam rangka mengkaji lebih mendalam ilmu rekayasa, hidrolika, aliran pada belokan sungai, dengan mengetahui prilaku aliran dapat dilakukan usaha untuk membuat suatu pencegahan terhadap terjadinya kerusakan yang disebabkan oleh energi aliran, dan dapat memanfaatkan potensi air secara optimal.

Hal-hal khusus yang ada dalam buku ini tentang teoriteori dasar saluran terbuka, distribusi kecepatan pada suatu penampang aliran pada saluran terbuka, angkutan sedimen yang terkait langsung dengan gerak mula sedimen dan secara umum tentang rekayasa sungai, serta beberapa penelitian tentang belokan sungai atau model belokan saluran tanpa hambatan dan dengan hambatan pilar, beberapa bangunan sumber air lainnya.

Dalam penulisan buku ini dapat tersusun atas dukungan dari banyak pihak, khususnya rekan-rekan dosen Jurusan Teknik Sipil Fakultas Teknik Universitas Tadulako, oleh karena itu penulis manyampaikan ucapan terima kasih kepada semua pihak yang telah membantu baik moriil maupun materil.

Kritik dan saran kepada pengguna untuk penerbitan selanjutnya, sehingga partisipasi dan sumbangsih semua pihak 
yang telah membantu dalam proses penyusunan buku ini akan menjadi amal ibadah dan memperoleh Ridha dari Allah SWT.

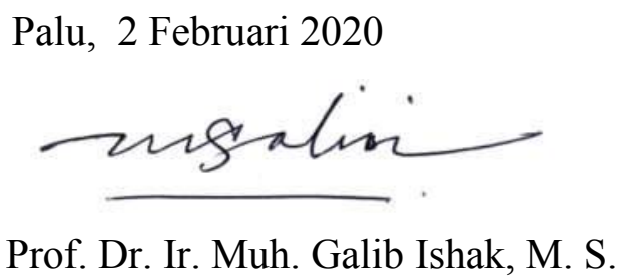




\section{DAFTAR ISI}

MODUL 1. MORFOLOGI SUNGAI......................................1-1

1.1 Pendahuluan ....................................................................1-1

1.2 Morfologi Sungai ………………………………………........

MODUL 2. REKAYASA SUNGAI ......................................2-1

2.1 Pengertian Rekayasa Sungai ...............................................2-1

2.2 Lingkup Rekayasa Sungai ........................................................2-2

MODUL 3. KONSERVASI SUNGAI ...................................3-1

3.1 Pendekatan Teknik Sungai dan Konservasi Air ......................3-1

3.2 Upaya Pengelolaan Daerah Aliran Sungai ................................3-2

3.3 Sempadan Sungai dan Dampak Negatif Hilangnya Sempadan Sungai

\section{MODUL 4. BENTUK SUNGAI DAN BANGUNAN}

PERSUNGAIAN....................................................4-1

4.1 Karakteristik Daerah Aliran Sungai .......................................4-1

4.2 Proses Fluvial dan Pembentukan Sungai.................................4-2

4.3 Bentuk dan Morfologi Sungai ..................................................4-6

MODUL 5. SALURAN TERBUKA..................................5-1

5.1 Aliran pada Saluran Terbuka...................................................5-1

5.2 Klasifikasi Aliran Saluran Terbuka dan Pengelompokan

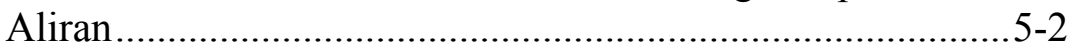

5.3 Persamaan Aliran ............................................................. 5-4

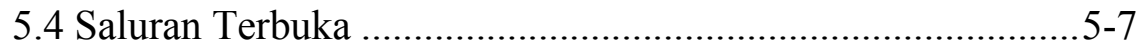

5.5 Aliran Melalui Penampang....................................................5-9

5.6 Tampang Ekonomis...........................................................5-12

5.7 Kecepatan Maksimum yang Diizinkan .................................5-14

MODUL 6. ALIRAN PADA BELOKAN SALURAN..........6-1

6.1 Gerusan pada Belokan Saluran............................................ $6-1$

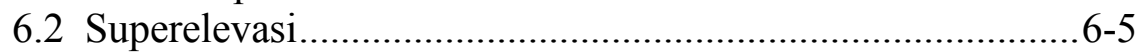

6.3 Distribusi Kecepatan pada Belokan Sungai .........................6-11 
7.1 Sedimen di Sungai ..........................................................

7.2 Pergerakan Sedimen ..........................................................

7.2.1 Awal Sedimen Dasar Bergerak ..................................... 7-2

7.2.2 Enegi/Gaya yang Bekerja Pada Partikel Sedimen .......7-6

7.2.3 Karakteristik Sedimen.................................................

7.2.4 Sedimentasi ..............................................................

\section{MODUL 8. HITUNGAN ANGKUTAN SEDIMEN}

8.1 Transpor Sedimen..................................................................

8.2 Angkutan sedimen dasar .....................................................

8.2.1 Analisa Angkutan Sedimen Suspensi dengan Metode Sesaat ............................................................ 8-10

8.3 Analisa Angkutan Sedimen dengan Metode L.C. Van Rijn $8-11$

8.4 Analisa Angkutan Sedimen Dengan Metode Peter-MeyerMuller

MODUL 9. KERUSAKAN SUNGAI...................................9-1

9.1 Kerusakan dan Pengaman Sungai ........................................... 9-1

9.2 Indikator Komponen Aspek Dinamik Morpologi Sungai .......9-2

9.3 Kerusakan Sungai dan Bangunan Pengaman Sungai ..............9-3

MODUL 10. PENGENDALIAN BANJIR SUNGAI.............10-1

10.1 Banjir dan Penyebabnya .................................................10-1

10.2 Pengendalian Banjir ......................................................10-2

MODUL 11. PARAMETER HIDROLIKA SUNGAI..........11-1

11.1 Parameter Sungai..........................................................11-1

11.2 Kedalaman Normal.....................................................11-2

11.2.1 Bilangan Froude ....................................................11-4

11.2.2 Bilangan Reynold ...................................................11-5 
MODUL 12. Hukum Kontinuitas, Kekekalan Energi dan Momentum..................................................12-1

12.1 Hukum Kontinuitas ..............................................................12-1

12.2 Aliran Permanen Seragam (Steady uniform flow) ..............12-2

12.3 Distribusi Kecepatan ......................................................12-4

12.4 Tegangan Geser dan Distribusi Kecepatan .........................12-5

12.5 Sifat-sifat aliran Kritis ...................................................12-7

\section{MODUL 13. PENINGGIAN MUKA AIR DAN}

BENDUNG ..........................................................13-9

13.1 Latar Belakang ................................................................13-9

13.2 Pengertian dan Tujuan Bendung …………….................13-10

13.3 Pemilihan Lokasi Bendung ...........................................13-10

13.4 Pemilihan Tipe Bendung ……………………..............13-11

MODUL 14. PERENCANAAN BENDUNG ........................14-13

14.1 Menentukan Elevasi Mercu Bendung. .............................14-13

14.2 Perhitungan Tinggi Air Banjir di hilir Bendung. ..............14-15

14.3 Pintu Pengambilan (Intake) .............................................14-16

14.4 Penentuan Lebar Efektif Bendung ....................................14-17

14.5 Perhitungan Kolam Olak/Peredam Energi .......................14-18

14.6 Analisis Stabilitas Bendung...........................................14-24

\section{DAFTAR PUSTAKA}

TENTANG PENULIS 


\section{DAFTAR TABEL}

Tabel 3-1. Alternatif penanganann masalah DAS ........................3-3

Tabel 4-1. Klasifikasi diameter sedimen dasar

(Winditiatama,2011)............................................4-15

Tabel 5-1. Pengelompokan aliran berdasarkan bilangan

Froude dan Reynolds pada saluran terbuka................5-4

Tabel 5-2. Nilai koefisien Manning .........................................5-10

Tabel 5-3. Tipe dan bentuk penampang saluran ekonomis ........5-13

Tabel 5-4. Kecepatan maksimum yang diijinkan menurut Fortier dan Scobey..............................................5-15

Tabel 6-1. Besaran aliran dan dimensi saluran model

Mozaffari dkk. (2011) ...........................................6-3

Tabel 6-2. Dimensi hidrolis model (Blanckaert 2002) ................6-4

Tabel 6-3. Ukuran dan hidrolis model (Yen dkk., 1971) ...........6-8

Tabel 8-1. Klasifikasi Ukuran Butir .............................................8-4

Tabel 14-1. Nilai koefisien kontraksi pada Pilar:....................14-17

Tabel 14-2. Tipe pondasi batuan ..........................................14-26

Tabel 14-3. Koefisien jenis tanah...................................... 14-27 


\section{DAFTAR GAMBAR}

Gambar 4-1. Zona pemasok sedimen ......................................4-3

Gambar 4-2. Zona transportasi sedimen..................................4-4

Gambar 4-3. Zona pengendapan .............................................4-4

Gambar 4-4. Dataran banjir dan formasi delta ...........................4-6

Gambar 4-7. Skema belokan dan proses meandering ..............4-11

Gambar 4-8. EntrenchmentRatio mewakili tipe sungai

(Rosgen, 1996) .................................................4-13

Gambar 4-9. Perbandingan antara lebar dan dalam (W/D)

tipe sungai (Rosgen, 1996).................................4-14

Gambar 4-10. Pengukuran kemiringan ..................................4-15

Gambar 4-11. Material penyusun dasar sungai

(Rosgen,1996) ...............................................4-16

Gambar 4-12. Bentuk sungai ....................................................4-18

Gambar 4-13. Tanggul sungai ................................................4-20

Gambar 4-14. Timbunan bongkah batu alam ............................4-21

Gambar 4-15. Susunan blokbeton berbentuk segi panjang ........4-21

Gambar 4-16. Susunan bronjong untuk memperkuat struktur tanah ...................................................4-22

Gambar 4-17. Konsolidasi pondasi ........................................4-24

Gambar 4-18. Krib pada sungai ..............................................4-25

Gambar 4-19. Ambang sungai (Groundsill).............................4-26

Gambar 5-1. Bentuk potongan melintang saluran.......................5-2

Gambar 5-2. Persamaan energi pada saluran terbuka .................5-5

Gambar 5-3. Penerapan dalil momentum....................................5-7

Gambar 6-1. Model saluran penelitian (Mozaffari dkk., 2011) ................................................................ $6-2$

Gambar 6-2. Potongan melintang permukaansedimen pada sudut belokan $70^{\circ}$ dan topografi aliran untuk debit 63 lt/dt (Mozaffari dkk., 2011) ....................6-3

Gambar 6-3. Arah kecepatan melintang saluran dan topografi dasar padabelokan (Blanckaert, 2002) $6-4$

Gambar 6-4. Sketsa belokan saluran penelitian (Yen dkk.,1971) $6-8$

Gambar 6-5. Topografi dasar saluran untuk model penampang trapesium (Yen dkk., 1971) $6-9$ 
Gambar 6-6. Koefisien superelevasi (Yen dkk. 1971).............6-10

Gambar 6-7. Pengukuran profil kecepatan pada potongan melintang $180^{\circ}$ (Mozaffari, 2011)

Gambar 6-8. Profil kecepatan beberapa model penelitian untuk debit 63 lt/dt(Mozaffari, 2011)

Gambar 6-9. Model belokan saluran di Delft University of Technology (Booij, 2003) $6-13$

Gambar 6-10. Hasil pengukuran kecepatan sekunder atau biasa disebut kecepatan arah melintang saluran (Booij, 2003) $6-14$

Gambar 6-11. Profil vertikal terhadap pengukuran komponen kecepatan (Booij, 2003) $6-14$

Gambar 6-12. Model fisik penelitian (de Vriend,1979 dan Rozovskii, 1961 dalam Duan, 2004) $6-15$

Gambar 6-13. Model saluran yang digunakan dalam penelitian (Masjedi dkk., 2007).

Gambar 6-14. Grafik stabilitas gerusan pada posisi $60^{\circ}$

(Masjedi dkk., 2007)

Gambar 6-15. Gerusan dengan pilar percobaan dengan debit 24, 28, 30, dan $32 \mathrm{ltr} / \mathrm{dt}$ 6-19

Gambar 6-16. Profil maksimum dalam arah melintang saluran dengan variasi kedalaman pada debit

32 ltr/dt (Masjedi dkk., 2007). $6-20$

Gambar 6-17. Profil maksimum gerusan dengan dengan debit yang berbeda pada posisi 60 derajat (Masjedi dkk., 2007).

Gambar 7-1. Grafik Shield Modifikasi (Rouse 1939, ASCE 1975)

Gambar 7-2. Diagram gaya yang bekerja pada partikel sedimen $7-6$

Gambar 7-3. Deskripsi umum proses transpor sedimen...............7-7

Gambar 7-4. Gambar aliran laminer dan turbulen . 7-9

Gambar 7-5. Skema angkutan sedimen. (Sumber, Soewarno $(2000 ; 646)$ $7-10$

Gambar 8-1. Model angkutan sedimen (Ron Parker 2002)..........8-2

Gambar 8-2. Klasifikasi angkutan sedimen $8-3$

Gambar 8-3. Grafik U* oleh Vanoni - Brooks...........................8-10

Gambar 9-1. Potongan melintang pada saluran sungai ................9-3

Gambar 9-2. Perubahan bentuk meander $9-3$ 
Gambar 9-3. Bronjong kawat ................................................9-5

Gambar 9-4. Blok beton ..............................................................9-5

Gambar 9-5. Pasangan batu......................................................... 9-6

Gambar 10-1. Skema pengendalian banjir .............................. 10-3

Gambar 11-1. Parameter fisik sungai ........................................11-2

Gambar 12-1. Kontinuitas aliran dalam suatu pias ................... 12-2

Gambar 12-2. Gaya-gaya pada aliran seragam ........................12-4

Gambar 12-3. Distribusi kecepatan pada berbagai bentuk.........12-4

Gambar 12-4. Pola distribusi kecepatan sebagai fungsi kedalaman.......................................................... 12-5

Gambar 12-5. Profil kecepatan pada bidang batas hidraulik halus............................................................... 12-6

Gambar 14-1. Contoh lokasi dan potongan melintang sungai akan dibangun bangunan.......................14-15

Gambar 14-2. Posisi intake ......................................................14-16

Gambar 14-3. Kolamolakan tipe Vlughter ..............................14-19

Gambar 14-4. Kolamolak tipe Schoklitsch .............................14-20

Gambar 14-5. Kolam olakan tipe Bucket...............................14-21

Gambar 14-6. Kolam olakan tipe Bucket ................................14-22

Gambar 14-7. Kolam olakan tipe USBR Type IV ..................14-23 


\section{MODUL 1. MORFOLOGI SUNGAI}

1. Sasaran Pembelajaran

- Mahasiswa mampu memahami Morfologi Sungai, lingkup konservasi air, pengelolaan DAS dan Rekayasa Sungai

- Mahasiswa memahami tentang morfologi sungai secara umum

2. Kemampuan yang mahasiswa yang menjadi prasyarat

Hidrolika, Hidrologi dan pengembangan sumber daya air.

3. Manfaat atau pentingnya bahan pembelajaran ini yaitu mahasiswa mampu memahami proses pembentukan sungai, sistemkonservasi dan pengelolaan sungai

4. Mengarahkan mahasiswa untuk mengerti terhadap materi ini yaitu dengan menampilkan beberapa contoh dan gambar serta memberi tugas mencari paper di internet sehingga akan memperkaya wawasan mereka..

\subsection{Pendahuluan}

Bumi terdiri atas lautan dan daratan yang terdiri atas pegunungan, gunung, bukit, dataran tinggi, dataran rendah, lembah, dan ngarai, luas daratan tersebut hampir semuanya terdiri atas daerah aliran sungai. Sedang daerah aliran sungai adalah suatu wilayah daratan yang secara topografi dibatasi oleh punggung-punggung bukit yang menampung dan menyimpan air hujan untuk kemudian menyalurkannya ke laut melalui sungai utama (Asdak, 2002). 
Secara umum sungai didefenisikan sebagai perpaduan antara alur sungai dan aliran air. Daerah aliran sungai merupakan lahan total dan permukaan air yang dibatasi oleh suatu batas topografi dan salah satu cara memberikan sumbangan terhadap debit suatu sungai yang merupakan suatu alur tempat mengalirnya air yang berasal dari hujan. (Sehyan, 1990).

Secara umum sungai dapat dibagi berdasarkan pengalirannya pada daerah hulu di pegunungan dengan lereng yang curam pada umumnya sungainya lurus sedang pada daerah lereng dengan topografi sangat landai dekat muara terjadi meander dan juga sering terbentuk delta. Di hulu pada umumnya sungai mengalir deras oleh karena kemiringan medannya yang sangat terjal, sedang sungai dibagian hilir sudah memasuki dataran rendah yang kemiringan medannya cukup landai, sehingga kecepatan air menjadi lambat dan sering terjadi pengendapan sedimen, yang menyebabkan sungai menjadi mudah berpidah-pindah arus dan berbelok-belok.

Debit Sungai adalah suatu volume air yang mengalir dalam satuan waktu tertentu, atau tinggi permukaan air sungai yang terukur. Pengukuran dilakukandengan alat AWLR (Automatic Water Level Record).

Sungai dengan kemiringan yang landai menyebabkan kecepatan air menurun sedimen akan mengendap yang menyebabkan terjadinya hambatan aliran air berakibat berubahnya sungai menjadi berbelok-belok dan semakin lebar. Dari hal tersebut di atas sungai dengan aliran yang tetap, berbagai macam 
morfologi ada sungai belok menjadi lurus dan sebaliknya,dan ada yang menganyam menjadi luirus atau berbelok. Pada bagian hulu sungai pada umumnya terjal dimana aliran yang terjadi adalah aliran kritis - turbulen, sedang pada bagian hilir dimana alirannya landai dan berbelok-belok sehingga terjadi aliran subkritis-turbulen.

Karakteristik yang spesifik pada sebuah belokan sungai, yaitu aliran air di belokan yang dapat menyebabkan gerusan pada bagian luar belokan, sedang bagian dalam belokan dalam terjadi endapan. Sungai mempunyai banyak masalah pada gerusan pada bagian luar tikungan sungai, pada bagian dalam tikungan terjadi endapan secara terus menerus (Mozaffari dkk, 2011, Masjedi dkk, 2007).

\subsection{Morfologi Sungai}

Morfologi sungai adalah ilmu yang mempelajari perubahanbentuk dan perilaku sungai terhadap dimensi ruang dan waktu, sifat dinamik yang punya hubungan satu dengan lainnya.Morfologi sungai dipengaruhi olehbesarnya kemiringan dan bentuk daerah aliran sungainya.

Studi morfologi sungai terbagi dalam 3 (tiga) dimensi, yaitu ; 1) Pegaruh fenomena alam; 2) Pergerakan air yang membawa endapan (sediment); dan 3) Pengaruh waktu ke waktu.

Hubungan morfologi sungai utamanya data hidrolika untuk keperluan desain bangunan teknik sipil di sungai yaitu 1) 
Pemeliharaan sungai; 2) Penggunaan air sungai; 3) Pengembangan wilayah sungai; dan 4) Pekerjaan Perbaikan dan pelestarian lingkungan sungai.

Unsur-unsur morfologi sungai untuk menunjang rancangan bangunan adalah parameter dan dimensi sungai; serta fenomena dan karakter sungai; geometri sungai dan waktu serta akibat perubahan morfologi sungai itu sendiri.Perubahan morfologi sungai yang berhubungan dengan aspek-aspek desain bangunn sipil yaitu :

1) Geometri sungai ; Menganalisi geometri sungai meliputi pembuatan topografi, alur, dan palungsungai serta lembah disekitar sungai. Untuk geometri diperlukan data :Lebar sungai; Panjang sungai; Kemiringan; Sudut belokan; elevasi dan azimuth arah arus.

2) Data Hidrograf; DataHidrograf diperlukan untuk menunjang desain persungaian. Data-data tersebut adalah:Volume banjir; Volume pengaliran; Tinggi muka air; Kecepatan naik dan turunnya pengaliran; lamanya waktu mencapai debit puncak; dan debit puncak.

3) Hidrolika Sungai; Pengaliran di sungai dapat berupa aliran laminer, turbulen, loncatan; pusarandan lain sebagainya. Pengaliran ini mengakibatkanpartikel dasar sungai bergerak tergantung dari butiran dan berat jenis sedimen. Berdasarkan Geometri sungai menyebabkan 
pengaliran yang berbeda-beda arah sehingga akan berdampak pada : a) Angkutan sedimen, b) Rembesanpada tebing sungai, c) Gerusan dasar sungai, d) gerusan tebing sungai akibat adanya gaya sentrifugal, mengakibatkan terjadinya aliran spiral dan pusaran air, e) Perubahan karakter sungai terasebut membentuk sungai yang berbelok dan menganyam. 


\section{MODUL 2. REKAYASA SUNGAI}

1. Sasaran Pembelajaran

- Mahasiswa dapat memhami pendekatan rekayasa sungai

- Mahasiswa mampu mengemukakan pendapat tentang prilaku sungai

2. Kemampuan yang mahasiswa yang menjadi prasyarat

Hidrolika, Hidrologi dan pengembangan sumber daya air.

3. Manfaat atau pentingnya bahan pembelajaran ini yaitu mahasiswa mampu memahami sistemkonservasi dan pengelolaan sungai

4. Mengarahkan mahasiswa untuk mengerti terhadap materi ini yaitu dengan menampilkan beberapa contoh dan gambar serta memberi tugas mencari paper di internet sehingga akan memperkaya wawasan mereka.

\subsection{Pengertian Rekayasa Sungai}

Sungai adalah sebuah system pengaliran air yang melewati alur alam yang secara menerus secara alami dan menyesuaikan dirinya terhadap perubahan lingkungan sekitarnya dalam bentuk aksi dan reaksi. Penyesuaian terhadap perubahan lingkungan sekitar ini bisa berjalan pelan tak terlihat dan berjangka panjang atau bisa juga berjalan sangat cepat mendadak.Rekayasa sungai didefenisikan sebagai ilmu tentang pemahaman dan mempelajari perilaku sungai dan cara pemanfaatan sungai potensi sungai secara efisien. 
Dampak dari perubahan yang terjadi di sungai tidak hanya terjadi local tapi bisa jauh ke hulu dan ke hilir. Penyesuaian atas aksi terhadap sungai dapat berdampak perubahan tampang melintang, kemiringan memanjang, sinusitas, bentuk palung, kecepatan air, nilai kekasaran tebing dan dasar sungai dalam tampang memanjang tergantung jenis dan intensitas dampak. Setelah terjadi dampak itu sungai akan memulihkan dirinya ke kondisi keseimbangan yang dapat berlangsung cepat dalam beberapa minggu atau dapat juga berlangsung lama dalam beberapa puluh tahun.

Tujuan dari aplikasi ilmu rekayasa sungai yaitu untuk mendapatkan manfaat untuk kebutuhan manusia dan meminimalkan dampak negatif akibat banjir serta bagaimana melestarikan sungai tersebut. Pemanfaatan sungai untuk keperluan manusia yaitu ; a) Air untuk keperluan pertanian; b) keperluan navigasi; c) Air bersih untuk keperluan air minum; d) dimanfaatkan untuk PLTA, dan lain sebagainya.

\subsection{Lingkup Rekayasa Sungai}

Lingkup dari ilmu rekayasa sungai meliputi Pengaturan Saluran, Pengaturan Debit dan Pengaturan Muka Air Sungai. Dengan demikian ketiga aspek ini menjadi perhatian utama sehingga perlu diketahui maksud dari ketiga aspek tersebut. 
> Pengaturan saluran bertujuan untuk mendapatkan dimensi yang sesuai dengan kapasitas sungai yang meliputi lebar dan kedalaman saluran sungai.

$>$ Pengaturan debit dimaksudkan untuk mengontrol debit sehingga mencegah banjir dan untuk pemanfaatan air untuk kebutuhan manusia. Curah hujan yang berubah - ubah tergantung pada musim akan berdampak pada volume air yang mengalir disungai. Pengaturan debit dapat dengan cara membangun bendungan besar.

> Pengaturan tinggi muka air di sungai dimaksudkan untuk meninggikan muka air sungai dengan tujuan pemanfaatan air berupa pertanian dan air minum. 


\section{MODUL 3. KONSERVASI SUNGAI}

1. Sasaran Pembelajaran

- Mahasiswa mampu konservasi airdan pengelolaan DAS

- Mahasiswa mampu mengemukakan pendapat tentang ekohidrolik

2. Kemampuan yang mahasiswa yang menjadi prasyarat

Hidrolika, Hidrologi dan pengembangan sumber daya air.

3. Manfaat atau pentingnya bahan pembelajaran ini yaitu mahasiswa mampu memahami proses pembentukan sungai, sistemkonservasi dan pengelolaan sungai

4. Mengarahkan mahasiswa untuk mengerti terhadap materi ini yaitu dengan menampilkan beberapa contoh dan gambar serta memberi tugas mencari paper di internet sehingga akan memperkaya wawasan mereka..

\subsection{Pendekatan Teknik Sungai dan Konservasi Air}

Konservasi sungai adalah ilmu yang mempelajari pemanfaatan air sungai dengan tujuan antara lain: irigasi, tenaga air, water supply, pengendalian banjir, drainase dan sebagainya. Aplikasi Rekayasa Sungai untuk pekerjaan sipil yaitu: bangunan pelindung tebing, bangunan pelindung dasar sungai, bangunan tanggul, Pengaturan saluran, Konstruksi pengalihan aliran sungai, Pengendalian aliran sedimentasi, dan Pengaturan muka air sungai. 
Konservasi air bertujuan untuk pemanfaatan air hujan yang tersimpan kedalam tanah seefisien mungkin serta bagaiman mengelola waktu pengaliran untuk mencegah banjir yang merusak. Tujuan konservasi secara umum adalah: 1) Menjaga kuantitas dan kualitas air tanah; 2) Mencegah kerusakan bantaran sungai; 3) Mencegah erosi dan sedimentasi; 4). Keseimbangan mencegah banjir dan kekeringan.

\subsection{Upaya Pengelolaan Daerah Aliran Sungai}

Upaya pengelolaan DAS adalah bagaimana mengatasi kerawanan terhadap banjir dan menjada kontinuitas pengaliran debit di sungai. Sehingga langkah yang ditempuh adalah dengan mengusahakan terjadinya infiltrasi baik pada bagian hulu, tengah dan hilir daerah aliran sungai. Berbagai cara dapat dilakukan untuk meningkatkan infiltrasi yaitu dengan penanaman rumput, belukar, dan pohon pohonan serta bangunan sediment trap.

Dengan reboisasi maka pengaruhnya terhadap tata air DAS akan meningkatkan resapan air tanah. Jika DAS ditanami kembali sekitar 20-30\% maka pengaruhnya terhadap terhadap keseiombangan air akan menjadi nyata. Tabel 3-1. Menjelaskan tentang alternatif penaganan pada DAS dapat dilihat sebagai berikut: 


\section{Tabel 3-1.Alternatif penanganann masalah DAS}

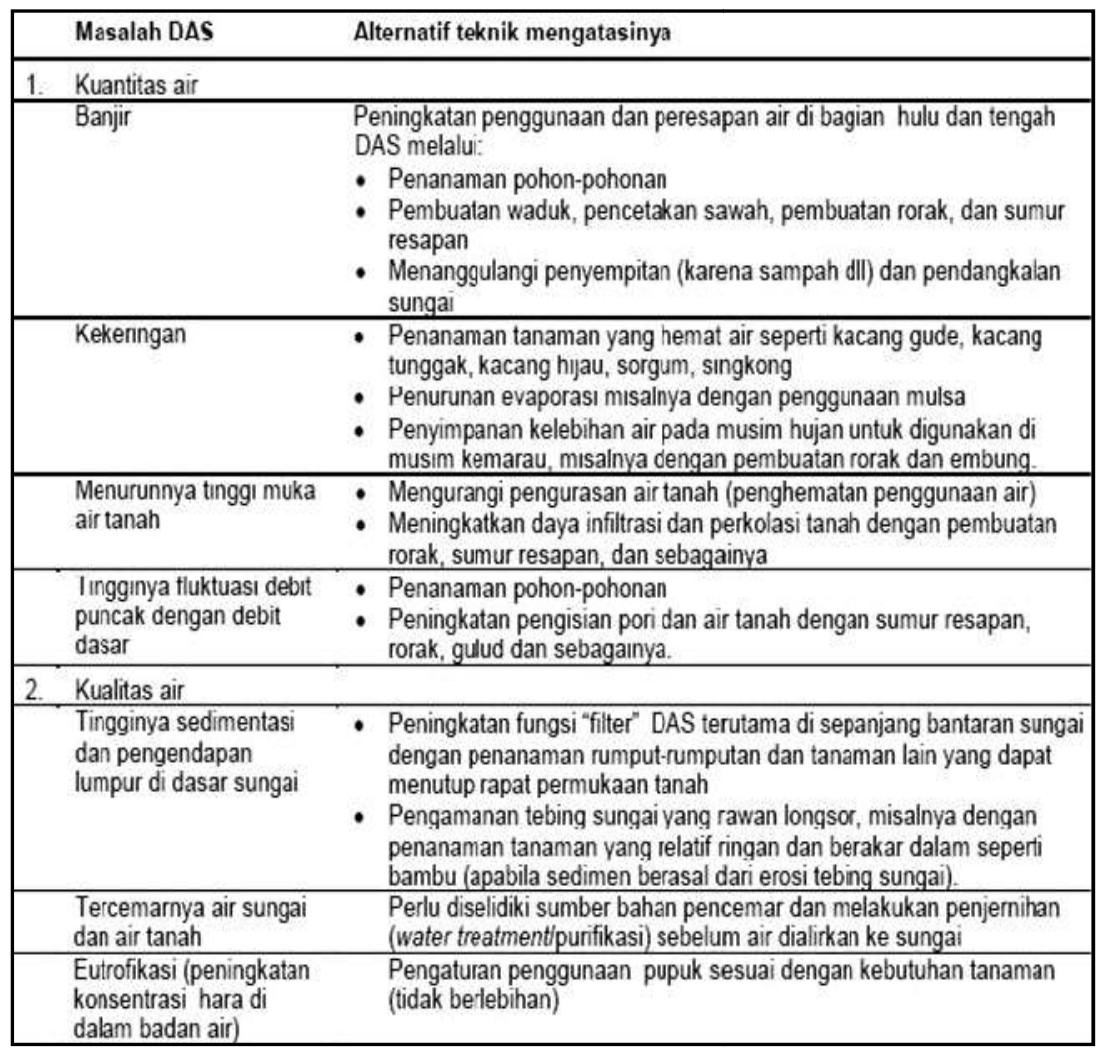

\subsection{Sempadan Sungaidan Dampak Negatif Hilangnya Sempadan}

Sungai

Daerah bataran sungai dan umumnya disebut sempadan sungai adalah zona penyangga antara ekosistem perairan (sungai) dan daratan. Penetapan sempadan sungai bertujuan untuk melindungi sungai dengan demikian fungsi sungai dapat berkelanjutan dan tetap terjaga untuk kepentingan manusia. Berdasarkan Peraturan Pemerintah Nomor 38 Tahun 2011 tentang Sungai dapat diuraikan fungsi sungai : 1) sungai 
bermanfaat sebagai penyedia air dan wadah air untuk memenuhi kebutuhan rumah tangga, sanitasi lingkungan, pertanian, perikanan, pembangkit tenaga listrik, transportasi, dan kebutuhan lainnya; 2) Sungai bermanfaat untuk penyalur aliran untuk mencegah banjir, dan menjaga ekosistem flora dan fauna.

\section{Soal Latihan 1}

1. Uraikan Lingkup pekerjaan Rekayasa Sungai dan Jenis-jenis pekerjaan yang berhubungan rekayasa sungai?

2. Uraikan hubungan antara morfologi sungai, konservasi DAS dan Geometrik Sungai dalam suatu kajian Rekayasa sungai?

3. Uraikan upaya-upaya pengelolaan DAS dan jelaskan pula dampak positif dan negatif akibat kegagalan pengelolaan DAS?.

4. Tujuan konservasi sungai terhadapa keseimbangan air dan kualitas air sangat jelas. Uraikan hubungan tersebut?

5. Bagaimana pendapat anda tentang upaya penanggulangan banjir dan erosi pada suatu kajian sungai. 


\section{MODUL 4. BENTUK SUNGAI DAN BANGUNAN PERSUNGAIAN}

1. Sasaran Pembelajaran

- Mahasiswa dapat mengetahui serta memahami bentuk-bentuk sungai dan bangunan persungaian

- Mahasiswa dapat mengetahui karakteristik DAS dan proses pembentukan sungai.

2. Kemampuan yang mahasiswa yang menjadi prasyarat Hidrolika, Hidrologi dan pengembangan sumber daya air.

3. Keterkaitan bahan pembelajaran dengan pokok bahasan lainnya sangat berkaitan dan merupakan satu kesatuan yang saling menunjang

4. Manfaat atau pentingnya bahan pembelajaran ini yaitu mahasiswa mampu memahami bangunan persungaian,karakteristik DAS dan proses pembentukan sungai

5. Petunjuk belajar mahasiswa, penjelasan tentang hal hal yang perlu dilakukan mahasiswa dalam mempelajari materi ini yaitu dengan menampilkan beberapa contoh dan gambar serta memberi tugas mencari paper di internet sehingga akan memperkaya wawasan mereka..

\subsection{Karakteristik Daerah Aliran Sungai}

Daerah Aliran Sungai (DAS) adalah daerah yang di batasi punggung-punggunggunung dimana air hujan yang jatuh pada daerah tersebut akanditampung oleh punggung gunung tersebut dan akan dialirkan melalui sungai-sungaikecil ke sungai utama (Asdak, 2002). Karakteristik DAS mencakup jenis tanah, tata guna lahan dan penutupan lahan, topografi, kemiringan dan 
panjang lereng yang akan memberikan respon curah hujan yang jatuh di wilayah DAS.

DAS sebagai suatu sistem yang berhubungan dengan sistem hidrologi dapat dinyatakan dalam suatu model yaitu proses air masuk dan air keluar daeri daerah aliran sungai.Hujan sebagai masukan utama dalam suatu yang sangat berpengaruh terhadap mekanisme proses masukan terhadap tanah, vegetasi dan aliran sungai, sedangkan sebagai output adalah debit aliran. Debit maksimum digunakan untuk identifikasi kemampuan dan kesimbangan DAS. Perencanaan pengelolaan dan monitoring DAS berdasarkan debit puncak dan debit andalan. Faktor utama pengaruh besarnya debit puncak yaitu karakteristik curah hujan dan karakteristik Daerah Aliran Sungai.

\subsection{Proses Fluvial dan Pembentukan Sungai}

Beberapa faktor alam mempengaruhi proses fisik morfologi sungai. Sejalan dengan aliran air mengalir ke hilir energi bergerak mengikuti transport air dan material di dalam palung sungai dan dataran banjir. Schumm (1977) membagi 3 zona interaksi air dan lahan dalam system fluvial sbb :

\section{A. Zona Pemasok Sedimen}

Merupakan bagian hulu DAS memiliki lembah berbentuk v yang langsung merupakan tebing sungai. Sungai memiliki kemiringan memanjang yang curam serta butiran sedimen yang besar. Aliran air mengalir deras dengan kecepatan 
tinggi. Banyak terjadi aktifitas erosi dari tebing dan dasar sungai.

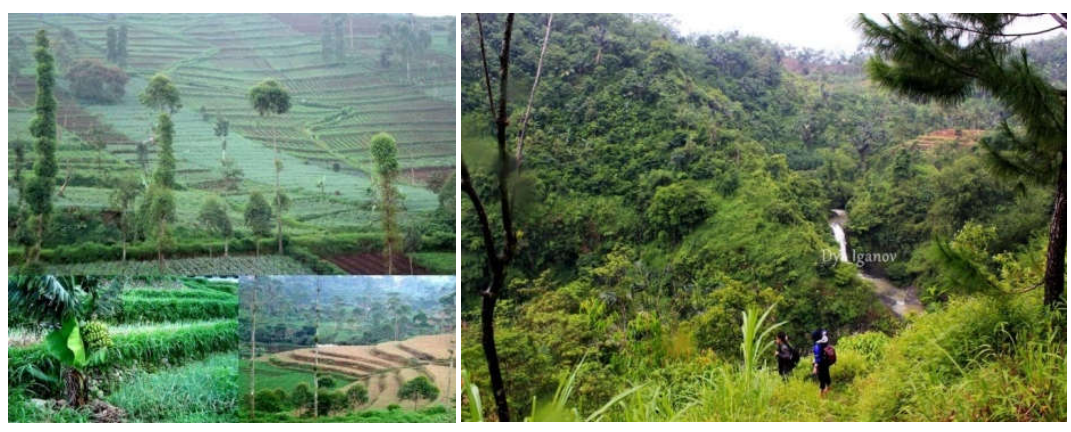

Gambar 4-1. Zona pemasok sedimen

B. Zona Transportasi Sedimen

Letaknya di hilir zona 1 sungai mulai membentuk dataran banjir. Di zona ini sedimen dari hulu yang berasal dari hasil erosi tebing dan dasar sungai didistribusi ke hilir. Sedimen bervariasi dari batu kerikil dibagian hulu sampai lumpur dan lempung di bagian hilir semua bergerak ke bawah. Meander mulai bergerak lateral, setelah banjir sedimen halus mengisi dataran banjir. 


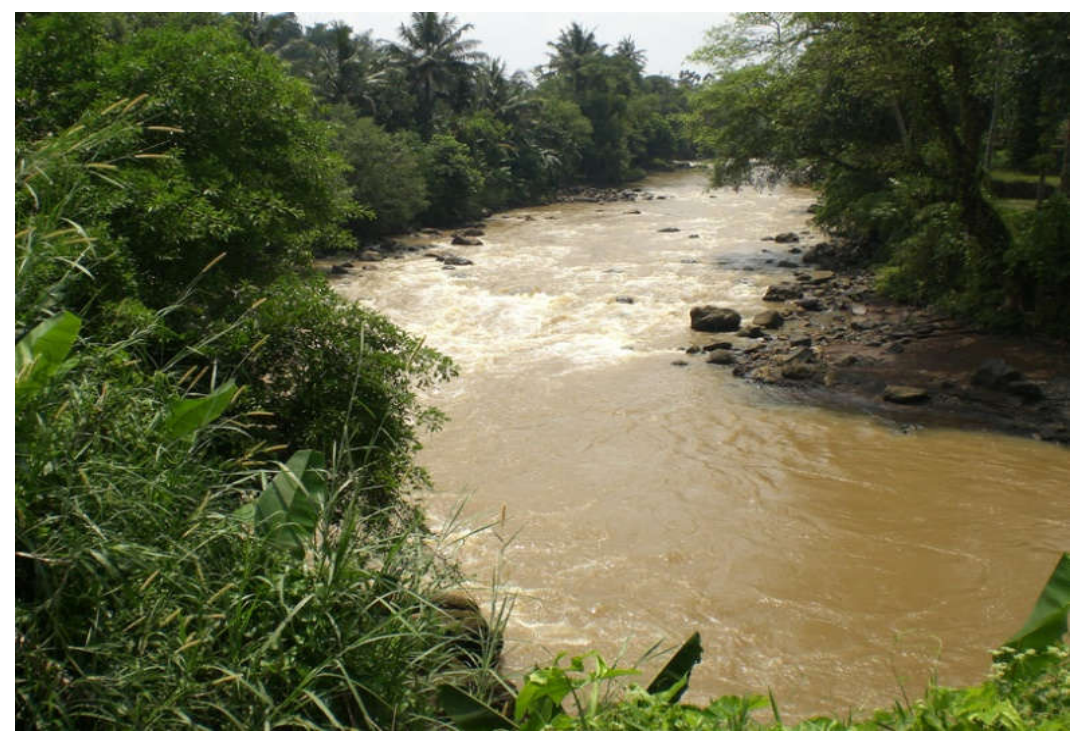

Gambar 4-2. Zona transportasi sedimen

C. Zona Pengendapan

Zona ini terletak paling bawah dekat dengan muara. Semua yang berasal dari zona 1 dan 2 terkumpul di sini. Di sungai alami zona ini merupakan daerah kehidupan satwa liar yang amat potensial.
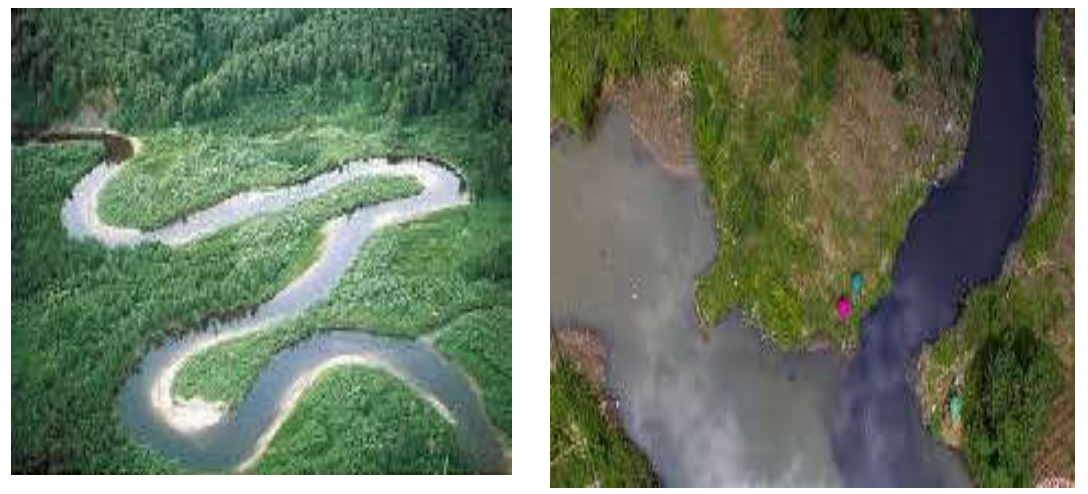

Gambar 4-3. Zona pengendapan 
D. Dataran Banjir dan Formasi Delta

Dengan berjalannya waktu, proses erosi berjalan terus baik melalui proses erosi permukaan maupun erosi yang terjadi di badan sungai, disertai longsoran-longsoran tebing, maka material hasil erosi tersebut akan terangkut ke arah hilir, sehingga terbentuk tebing-tebing sungai yang berfungsi sebagai batas alur sungai dan pembentukan meander sungai. Dengan banyaknya angkutan sedimen yang terbawa arus sungai, maka seterusnya sedimen tersebut akan diendapkan di daerah yang relatif rendah dan selanjutnya akan terbentuk dataran banjir.

Pada tempat-tempat tertentu di hilir dekat muara dimana kemiringan sungai relatif datar dan turbulensi aliran kecil akan terjadi endapan sungai yang selanjutnya akan membentuk "delta" sungai.

Hal lain yang akan terjadi adalah alur sungai akan menjadi lebih panjang dan kemiringan dasar sungai akan mengecil. Dasar sungai sebelah hulu akan bertambah tinggi akibat sedimentasi dan elevasi muka air banjir rata-rata akan lebih tinggi. Apabila ditinjau lebih lanjut maka makin lama akan terlihat bahwa dataran banjir akan bertambah tinggi. 


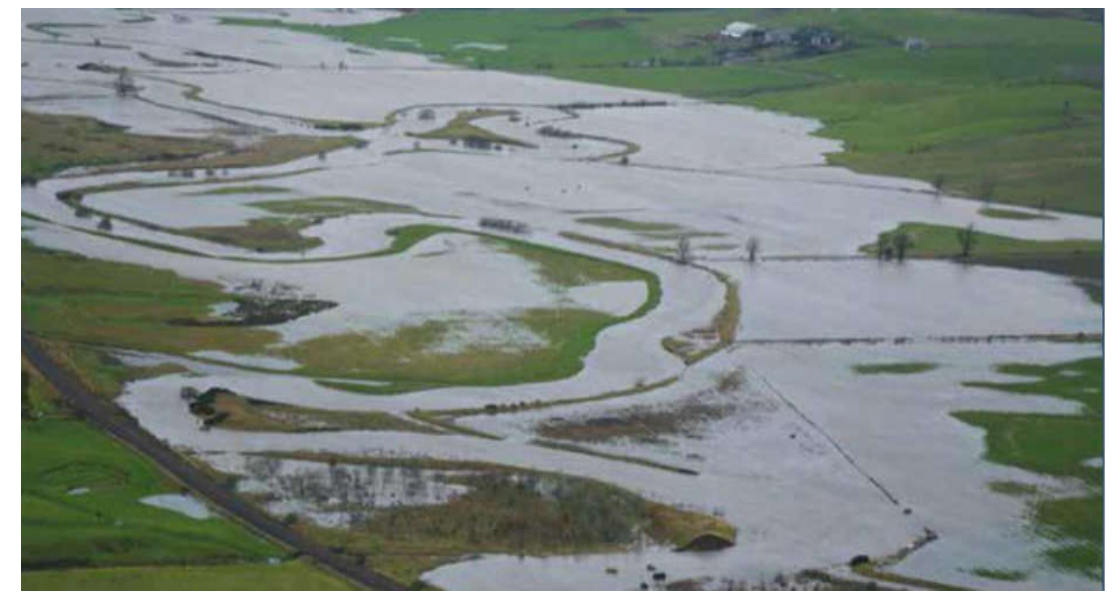

Gambar 4-4. Dataran banjir dan formasi delta

\section{E. Lensa Pasir/ Kipas Aluvial}

Hal lain yang banyak terjadi di sungai, adalah lensa pasir/kipas aluvial (alluvial fans). Lensa pasir terbentuk pada tempat dimana terjadi peralihan dasar sungai yang curam ke dasar sungai yang datar. Dengan adanya perubahan dasar sungai yang sekonyong-konyong dari curam ke dasar sungai yang datar, akan terjadi proses pengendapan terhadap beban sedimen yang cukup banyak, dan selanjutnya akan terjadi lensa-lensa pasir. Proses terjadinya lensa pasir hampir sama dengan proses terjadinya delta, dan keduanya akan memperkecil kemiringan dasar sungai beserta kecepatannya.

\subsection{Bentuk dan Morfologi Sungai}

Morfologi sungai sebagaimana tgelah dikemukakan di atas sangat berpengaruh terhadap proses geomorfologi yang 
terjadi di sungaiseperti proses erosi, longsor tebing, dan sedimentasi. Air yang mengalir di sungai sebagai fungsi dari gaya gravitasi bila daya dorong air lebih besar dari gaya tarik gravitasi terhadap sedimen lebih besar maka akan terjadi gerusan, dan sebaliknya akan terjadi endapan.

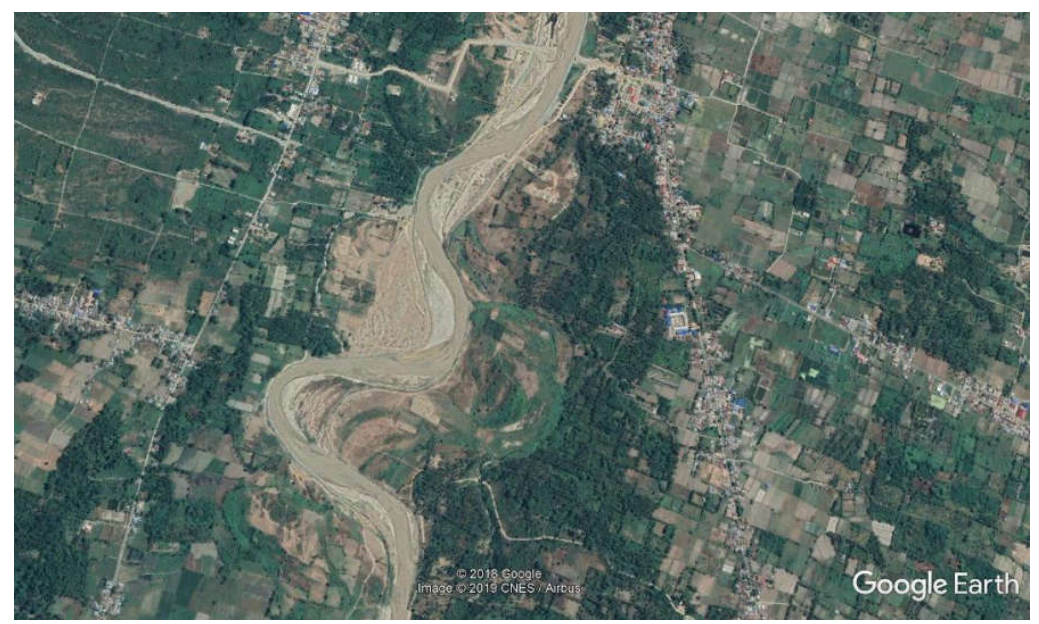

Gambar 4-5. Morfologi bagian tengah Sungai Palu.

Apabila kita akan mempelajari mengenai morfologi sungai, hal yang sangat membantu adalah melakukan studi terhadap profil dan situasi sungai secara keseluruhan. Dari situasi sungai secara keseluruhan akan nampak sejarah terjadinya sungai sebagai satu proses yang berubah terhadap waktu. Dengan adanya rekayasa perubahan terhadap sungai akan terlihat pengaruhnya terhadap sistem sungai secara keseluruhan. 


\section{A. Alur Bercabang (Braided Stream)}

Alur sungai bercabang adalah alur sungai yang terdiri dari beberapa alur dengan alur satu dan lainnya saling berhubungan. Penyebab utama terjadinya alur bercabang adalah tingginya beban sedimen dasar, sehingga arus sungai tidak mampu untuk mengangkut. Banyaknya sedimen lebih berpengaruh dibandingkan dengan besar butir terhadap pembentukan alur sungai bercabang. Apabila beban sedimen terlalu banyak, maka proses pengendapan akan terjadi, sehingga dasar sungai akan naik dan berakibat kemiringan dasar sungai juga bertambah dan selanjutnya akan terjadi keseimbangan. Dengan bertambahnya kemiringan dasar, maka kecepatan air akan naik dan selanjutnya akan terbentuk beberapa alur (alur bercabang), sehingga secara keseluruhan sungai akan menjadi lebih lebar. Hal lain yang terjadi pada alur bercabang adalah tebing yang relatif mudah tererosi. Apabila tebing alur sungai mudah tererosi, maka pada saat muka air tinggi lebar sungai akan menjadi lebih lebar dan pada saat air rendah endapan akan menjadi stabil dan terbentuk pulau-pulau.

Pada umumnya alur bercabang (braided channel) mempunyai kemiringan dasar yang cukup besar, beban sedimen dasar lebih besar dibandingkan dengan beban sedimen melayang, dan kandungan lumpur dan lempung 
relatif kecil.Tidak mudah melakukan kegiatan pekerjaan di daerah sungai yang bercabang, karena kondisi sungainya relatif tidak stabil, alinyemen alur sewaktuwaktu berubah dengan cepat, angkutan sedimen yang cukup besar, dan keadaan sungainya sulit dapat diperkirakan.
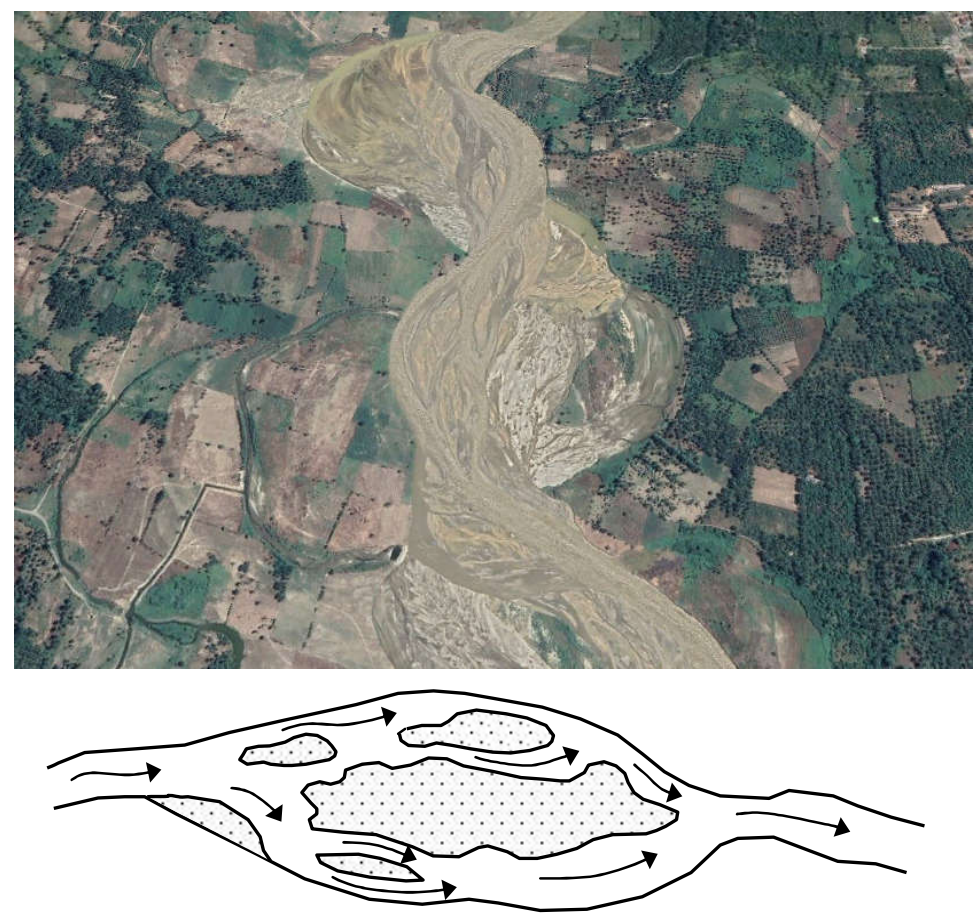

Gambar 4-6. Sungai bercabang-cabang (braided river)

B. Sungai Bermeander

- Sungai bermeander dapat didefinisikan sebagai sungai yang mempunyai alur berbelok-belok, sehingga hampir menyerupai huruf "S" berulang. Sungai 
bermeander terbentuk oleh adanya pergerakan menyamping akibat arus sungai terhadap formasi dan perubahan bentuk lengkungan sungai. Arus yang berbelok-belok juga akan terjadi pada sungai yang relatif lurus. Pada kenyataannya, hampir sebagian besar pada sungai yang lurus akan terjadi arus yang berbelok-belok dan akan terjadi endapan setempatsetempat yang selanjutnya dalam perkembangannya dapat terbentuk meander.

- Sungai bermeander adalah morfologi sungai yang berkelok-kelok akibat adanya pengikisan pada tebing sungai dan pengendapan pada sisi tebing lainnya. Dan hal ini terjadi secara terus menerus akibat adanya aliran dan akhirnya membentuk belokan pada sungai. Apabila proses ini berlangsung pada beberapa bagian sungai sehingga akanterjadi sungai yang berkelokkelok atau bisas disebut sebagai meander. 


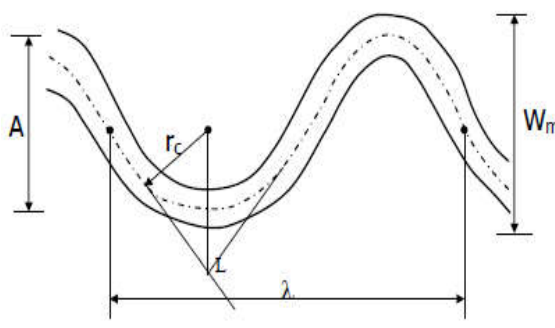

\section{Keterangan:}

$\lambda \quad$ : panjang meander

$\mathrm{W}_{\mathrm{m}}$ : lebar meander

$\mathrm{r}_{\mathrm{c}} \quad$ : jari-jari meander

A : Amplitudo

$\phi \quad$ : sudut arah lengkungan

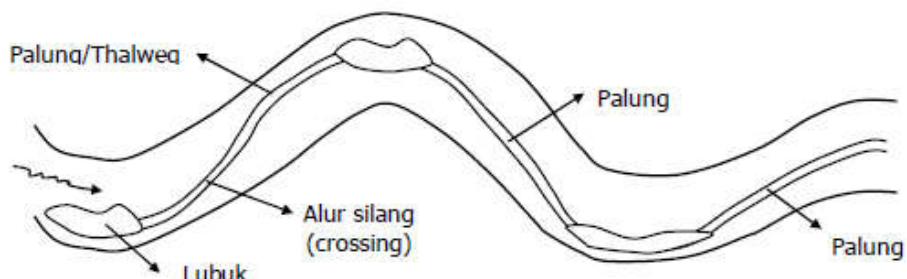

(Pool)

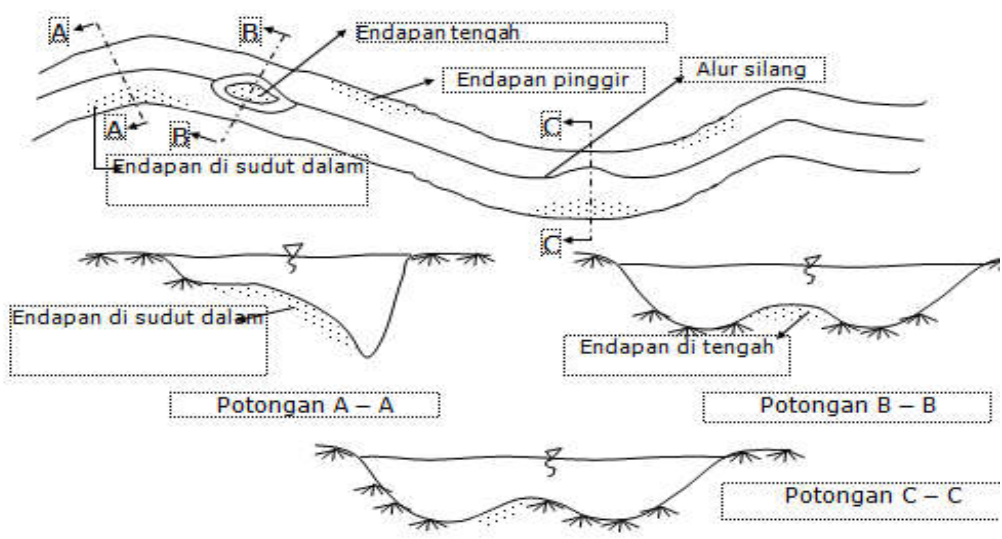

Gambar 4-5. Skema belokan dan proses meandering

Proses pembentukan alur sungai sebagai akibat proses erosi dan pengendapan tersebut akan berjalan terus, sehingga alur sungai akan terbentuk berupa alur yang menyerupai huruf "S" dan selanjutnya disebut Sungai Bermeander (Meandering River). Apabila proses erosi dan pengendapan 
terus berjalan dalam waktu yang cukup panjang, proses pembentukan meander berjalan terus dan pada kondisi tertentu lengkungan meander akan terputus dan terbentuk alur meander baru. Bekas meander tersebut lama kelamaan akan terisi oleh endapan sungai dan terbentuk lengkunganlengkungan danau (“oxbow”), dimana pengendapan akan lebih banyak terjadi pada posisi dekat alur aktif.

C. Langkah - Langkah Menentukan Morfologi Sungai

Untuk menentukan morfologi sungai maka beberapa faktor ciri khas sungai harus diketahui seperti data kedalaman aliran (d), lebar aliran banjir (Wb), lebar aliran (L), kedalaman maksimum aliran $\left(\mathrm{d}_{\mathrm{m}}\right)$, sinousitas, kemiringan aliran (slope), dan material dasar sungai $\left(\mathrm{d}_{50}\right)$.

Menurut teori (Rosgen, 1996) menjelaskan bahwa Entrenchment Ratio (ER) adalah perbandingan antara lebar sungai pada saat banjir (Wfpa) dan lebar sungai (Wbkf). adalah sebagai berikut:

Entrenc ment Ratio $=\frac{\text { lebar aliran banjir }(W f p a)}{\text { lebar aliran sungai }(W b k t)}$

Keterangan :

$\mathrm{W}_{f p a}=$ lebar aliran sungai pada saat banjir banjir (floodprone area width)

$\mathrm{W}_{b k t}=$ lebar sungai ( bankfull surface width)

Entrenchment Ratio pada sungai terdiri atas tiga kriteria yaitu: 
- Aliran berparit besar (Gambar 4-8) mewakili tipe sungai A, F dan G.

- Aliran berparit tengah (Gambar 4-8) mewakili tipe sungai B.

- Aliran BERPARIT KECIL (Gambar 4-8) mewakili tipe sungai $C, D$, dan $E$.

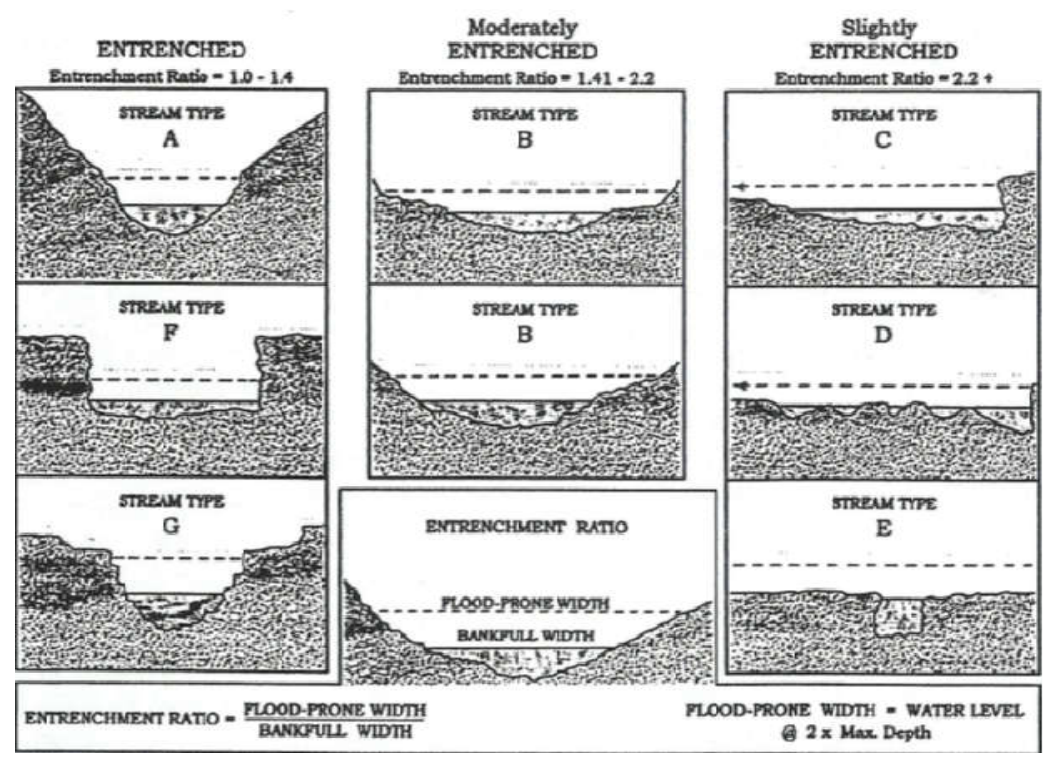

Gambar 4-6. Entrenchment Ratio mewakili tipe sungai (Rosgen, 1996) 


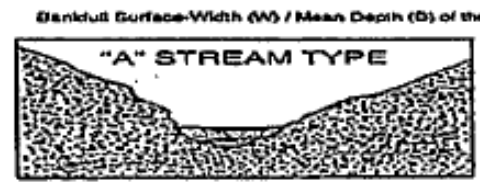

$w / D=0.0$

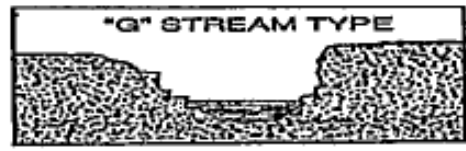

$w / D=$ a.o

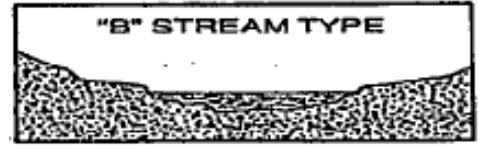

wo -10

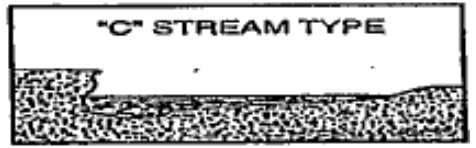

wo $=2 a$

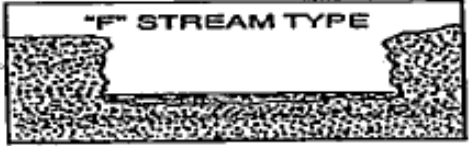

$w>0=a$

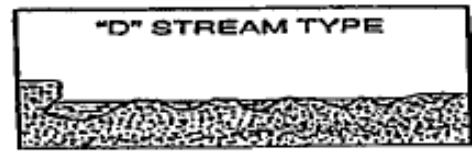

W/D $=80$

Gambar 4-7. Perbandingan antara lebar dan dalam (W/D) tipe sungai (Rosgen, 1996).

Kemiringan sungai merupakan hal yang penting dalam menentukan tipe jenis sungai. Berdasarkan pandangan morfologi klasik dibedakan bentuk sungai sebagai berikut : 1) Sungai berbentuk meander/berkelok; 2. Sungai berbentuk jalin/bercabang; 3) Sungai yang berbentuk lurus.

Untuk memudahkan penilaian dalam menentukan kemiringan sungai (slope) seperti terterapada gambar berikut : 


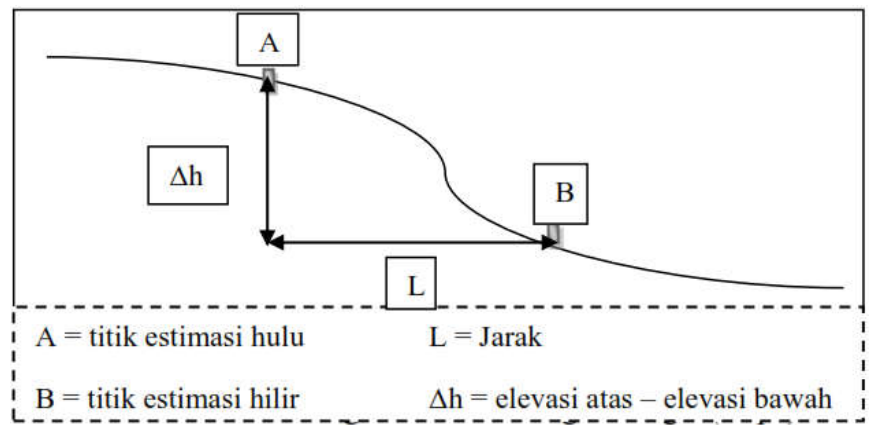

Gambar 4-8. Pengukuran kemiringan

Menghitung kemiringan sungai (slope) dengan menggunkan persamaan berikut :

$$
\text { Slope }=\frac{\mathrm{h}}{\mathrm{L}} \times 100 \%
$$

Sedimen dasar sungai "D-50"

Untuk mengetahui ukuran dan jenis sedimen yang membentuk dasar sungai untuk mengetahui ukuran butiran pasir dan kerikil maka dilakukan uji distribusi butiran. Di bawah ini merupakan beberapa jenis partikel penyusun material dasar sungai, yaitu:

Tabel 4-1. Klasifikasi diameter sedimen dasar

(Winditiatama,2011)

\begin{tabular}{|l|l|l|}
\hline A partikel & Ukuran & Sedimen \\
\hline Clay/lempung & $<1 / 256 \mathrm{~mm}$ & clay \\
\hline Slit/lanau & $\begin{array}{l}1 / 256-1 / 16 \\
\mathrm{~mm}\end{array}$ & slit \\
\hline Sand/pasir & $1 / 16-2 \mathrm{~mm}$ & sand \\
\hline Pebble/kerikil & $2-64 \mathrm{~mm}$ & gravel \\
\hline Cobble/kerakal & $64-256 \mathrm{~mm}$ & gravel \\
\hline Boulder/bongkah & $>256 \mathrm{~mm}$ & gravel \\
\hline
\end{tabular}




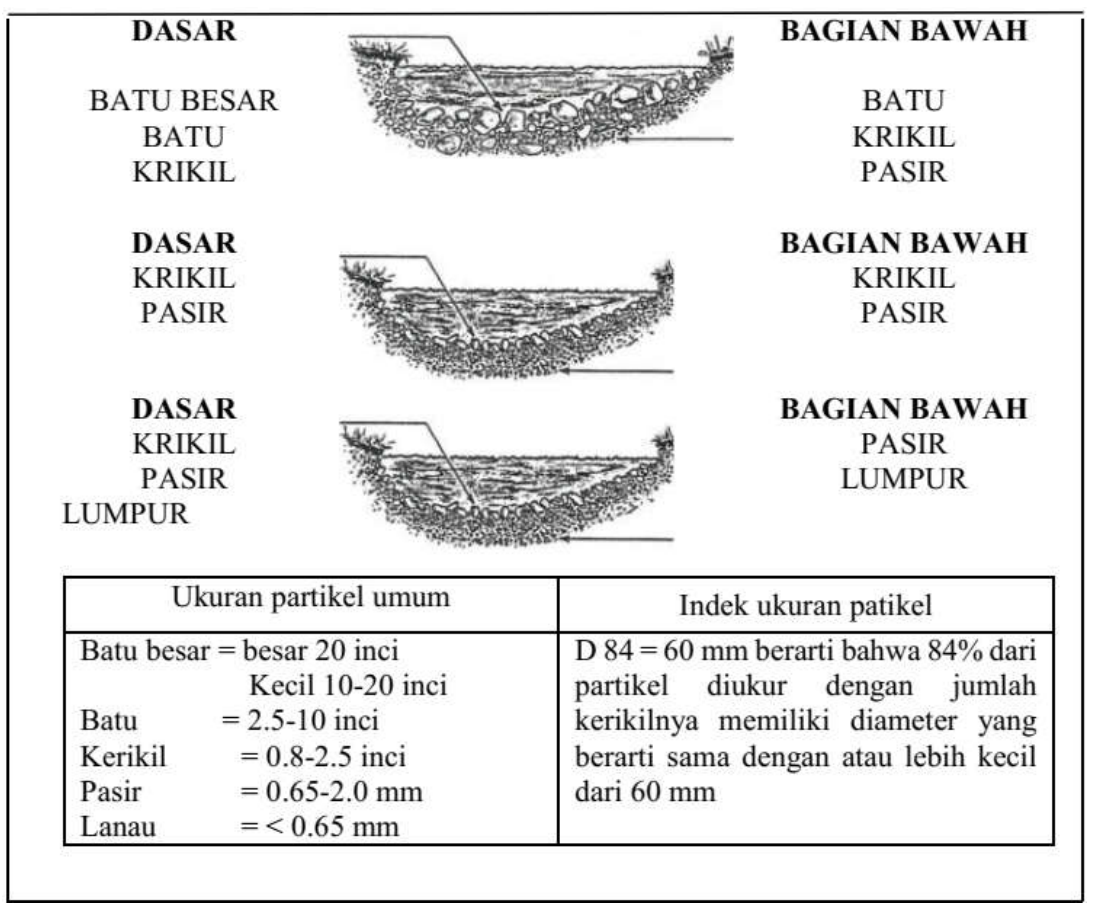

Gambar 4-9. Material penyusun dasar sungai (Rosgen,1996)

Untuk menentukan material dasar sungai, maka ukuran partikel yang diambil adalah ukuran partikel yang dominan atau dapat juga ditentukan dengan $\mathrm{d}_{50}$, dimana $\mathrm{d}_{50}$ merupakan $50 \%$ dari populasi sampel yang dikumpulkan.

Sungai juga dapat diklasifikasi menurut usianya. Ada beberapa metode yang digunakan untuk menentukan umur sungai, salah satu metode yang digunakan adalah mempertimbangkan sungai dari sudut geomorfologi. Sungai diklasifikasi menjadi sungai tua, dewasa dan sungai muda. Sungai muda adalah bentuk awal alur 
sungai. Alur terbentuk di permukaan tanah oleh aliran air. Biasanya bentuk alur seperti "huruf V", alur tidak beraturan dan terdiri dari beberapa bagian, bagian tertentu mudah tererosi dan bagian lain tidak mudah tererosi. Sebagai contoh sungai muda adalah sungai-sungai yang terletak di pegunungan beserta anak-anak sungai yang terbentuk oleh aliran permukaan.

Sungai dewasa adalah perkembangan selanjutnya dari sungai muda, dengan sifat-sifat lembah sungai yang cukup lebar, kemiringan dasar sungai relatif flat/datar, dan formasi tebing terbentuk dari hasil longsoran tebing sebelah hulu. Material dasar sungai terbentuk dari material bergradasi hasil dari endapan angkutan sedimen. Sungai dewasa mempunyai bantaran yang relatif sempit, dan biasanya meander sungai sudah terbentuk. Dataran sungai dewasa biasanya sudah mempunyai lebar yang cukup, sehingga ditempat tersebut lahannya sudah banyak yang dimanfaatkan oleh masyarakat, baik untuk pertanian maupun pemukiman. Untuk mencegah labilnya alur sungai dewasa, maka ditempat-tempat tertentu banyak dilakukan usaha stabilisasi sungai dan perlindungan tebing sungai untuk mencegah perubahan/ perpindahan alur sungai.

Sungai tua merupakan perkembangan selanjutnya dari sungai dewasa. Sebagai akibat dari proses erosi dan sedimentasi yang terus menerus, lembah sungai terbentuk 
dengan lebar sungai menjadi lebih lebar dan kemiringan dasar sungai menjadi lebih landai. Meander dan panjang meander yang terbentuk masih lebih sempit dari lembah sungainya.

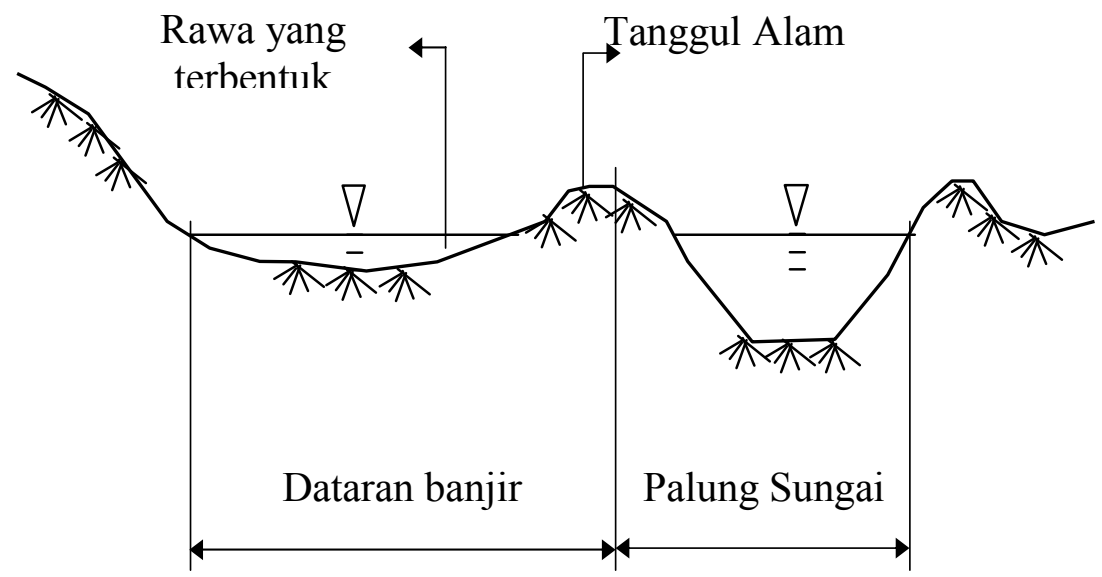

Gambar 4-10. Bentuk sungai

\section{Bangunan-bangunan Persungaian}

Beberapa Bangunan Persungaian Utama yang tidak termasuk bangunan pengendali sedimen:

1. Tanggul

2. Perkuatan Lereng

3. Konsolidasi Pondasi

4. Krib (Groyne)

5. Ambang (Groundsill)

6. Bendung (Weir)

7. Pintu Air (Gate/ Sluice) 


\section{A. Tanggul}

Tanggul merupakan bangunan persungaian utama sepanjang sisi kiri-kanan sungai. Fungsi utama tanggul adalah untuk melindungi kehidupan dan harta benda dari genangan akibat banjir, badai (gelombang pasang).

Tanggul alamiah ('natural levee') merupakan gambaran dari kondisi sistem sungai tua. Tanggul alamiah terbentuk dekat dengan alur sungai sebagai proses pengendapan material sungai akibat luapan banjir yang membawa sedimen. Material yang kasar akan terendapkan lebih dekat dengan palung sungai yang halus akan terendapkan agak jauh dari palung. Material kasar lama kelamaan membentuk tanggul alam, dan biasanya mempunyai kemiringan yang cukup curam, dan terjadi perbedaan elevasi dengan lokasi yang lebih jauh dari palung sungai dan terbentuklah rawa alami. 


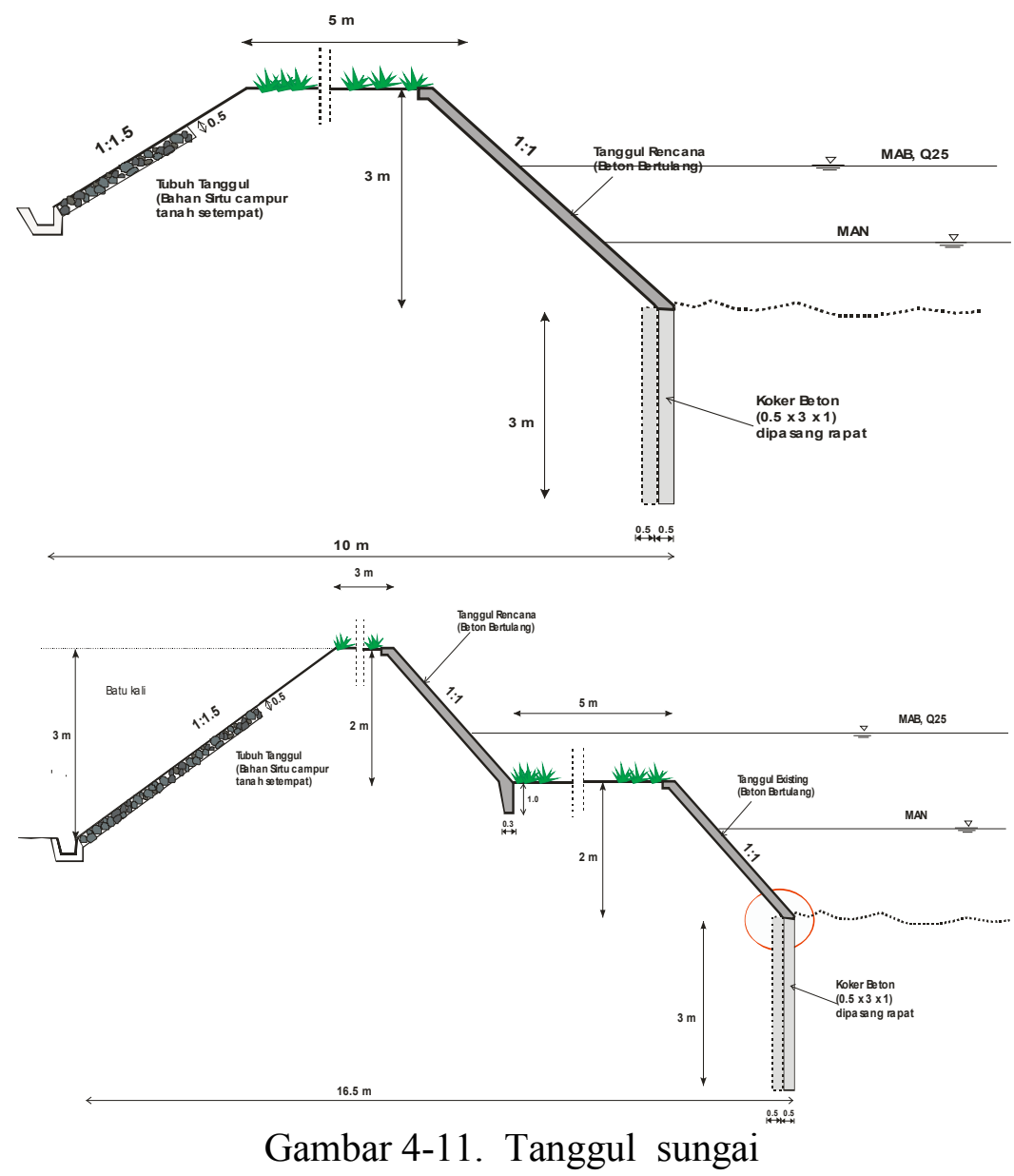

B. PerkuatanTebing atau Lereng Sungai

Bangunan perkuatanlereng diletakkan pada permukaan suatu lereng untuk melindungi suatu tebing sungai atau tanggul sungai dan bertujuan untuk meningkatkan kekuatan lereng atau tubuh tanggul. Konstruksi perkuatan lereng ditentukan berdasarkan : 1) Perkuatan lereng tanggul; 2) perkuatan tebing sungai (low dan; 3) perkuatan lereng menerus. 
Adapun Konstruksi Perkuatan lereng yaitu : 1) Pelindung lereng; 2) Pondasi dan pelindung kaki, 3) Konsolidasi, dan Pelindung mercu.

Jenis Perkuatan Lereng :

Rip-rap sebagai konstruksi peredam energi di hilir bendung dan berfungsi pula sebagai lapisan perisai untuk mengurangi kedalaman penggerusan setempat dan untuk melindungi tanah dasar di hilir peredam energi bendung. Konstruksi ini berupa susunan bongkahan batu alam atau blok-blok beton .
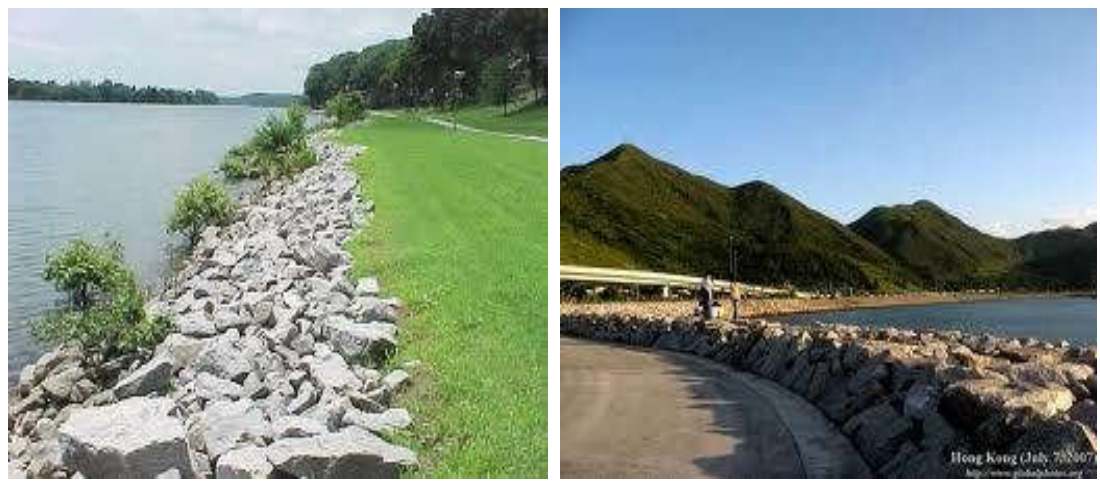

Gambar 4-12. Timbunan bongkah batu alam
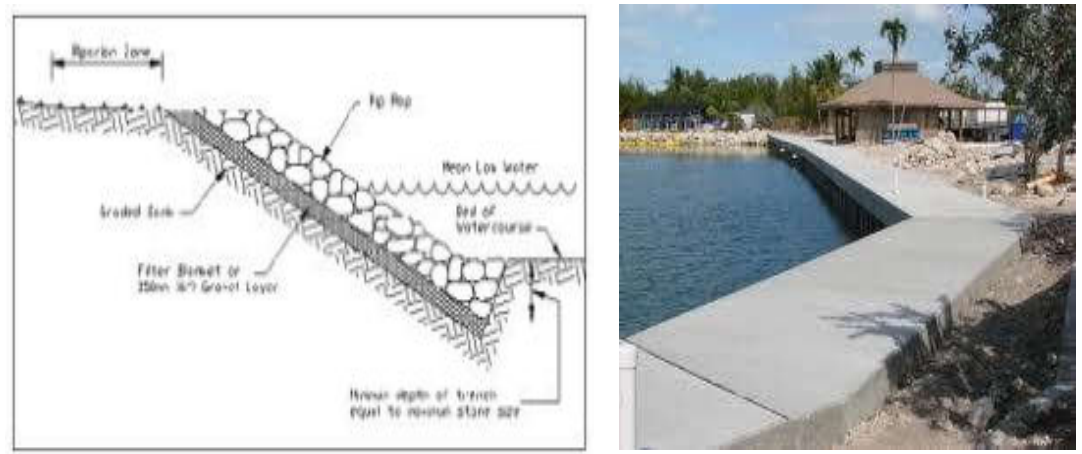

Gambar 4-13. Susunan blokbeton berbentuk segi panjang 
Bronjong adalah anyaman kawat baja yang dilapisi dengan seng atau galvanis dan bagian dalamnya diisi dengan batu berukuran besar untuk mencegah erosiAnyaman kawat baja ini dibuat dengan teknik lilitan ganda yang membentuk lubang-lubang berbentuk segi enam. Anyaman ini diikat secara kuat di antara sisisisinya sehingga tidak mudah terurai. Ikatan anyaman inilah yang membuat bronjong mampu menahan tanah sehingga tidak terjadi longsor atau erosi. Kawat yang digunakan berbahan baja berlapis galvanis sehingga kawat tidak mudah berkarat.

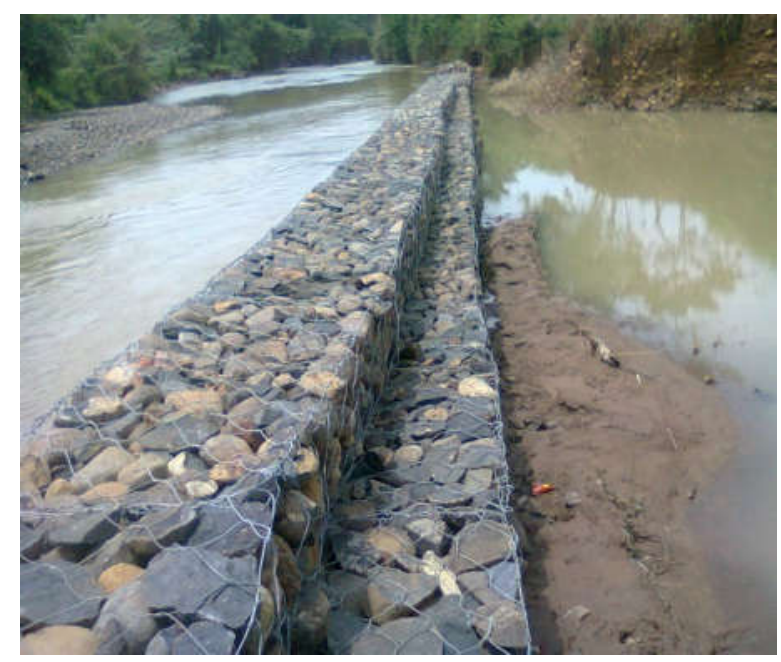

Gambar 4-14. Susunan bronjong untuk memperkuat struktur tanah

Fungsi bronjong di antaranya adalah melindungi dan memperkuat struktur tanah di sekitar tebing agar tidak terjadi longsor, tepi sungai, dan tepi tanggul. Bronjong 
juga bisa digunakan sebagai pembentuk bendungan untuk meningkatkan volume air sungai.

Bagian tepi sungai bisa mengalami erosi akibat arus sungai yang deras dan terus-menerus terjadi.

Konsolidasi Pondasi, Adalah suatu bangunan yang ditempatkan di depan atas pondasi atau yang berupa pelindung kaki perkuatan lereng. Tujuannya adalah mengurangi kecepatan arus, mencegah gerusan dasar sungai dan melindungi dasar sungai secara keseluruhan. Syarat yang dibutuhkan:

1. Blok-blok yang digunakan cukup berat

2. Mempunyai fleksibilitas yang memadai

3. Mempunyai kekasaran yang memadai

4. Pelaksanaan pembuatan mudah dan murah

5. Mudah dalam pemeriksaan. Jenis-jenis:

1. Lapis lindung batu (rip-rap)

2. Matras anyaman ranting dan matras anyaman ranting lapis tunggal

3. Matras balok kayu

4. Matras balok beton

Blok beton dan blok beton pracetak 


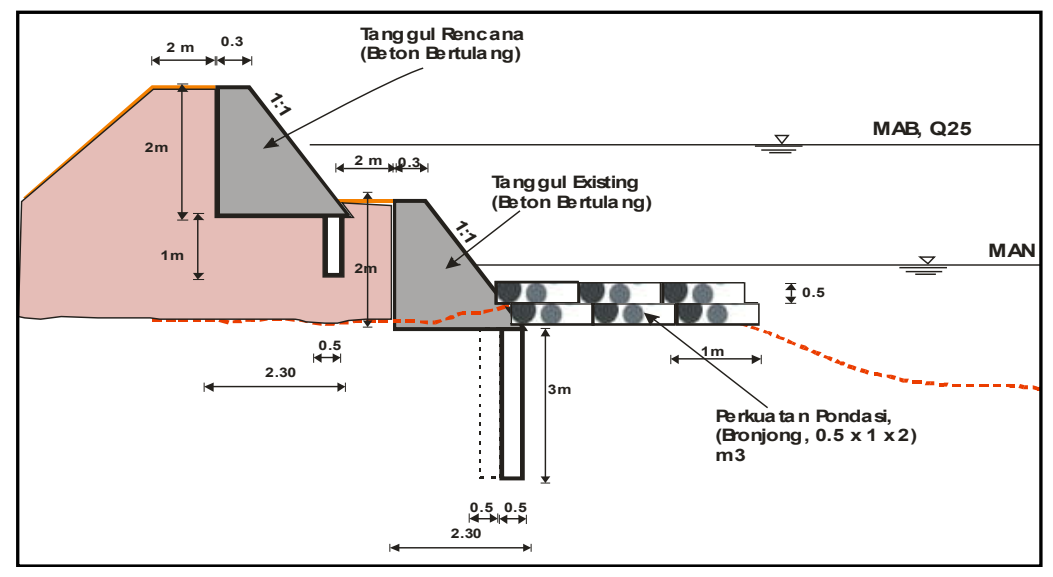

Gambar 4-15. Konsolidasi pondasi

Groyne/Krib adalah konstruksi yang dibangun pada tebing sungai hingga arah tengah yang berfungsi mengatur arus sungai, manfaatnya adalah:1) Mengkonsentrasikan arus sungai; 2) Menormalkan lebar dan dalamnya air pada suatu sungai; 3) menjamin keamanan tanggul atau tebing sungai thd gerusan; 4) Mengendalikan kecepatan agar supaya suangai tidak bermeander; dan 5) Mengatur arah arus sungai

Klasifikasi:
a) Krib permeabel
b) Krib impermeable
c) Krib semi-permeabel
d) Krib-krib silang dan memanjan 


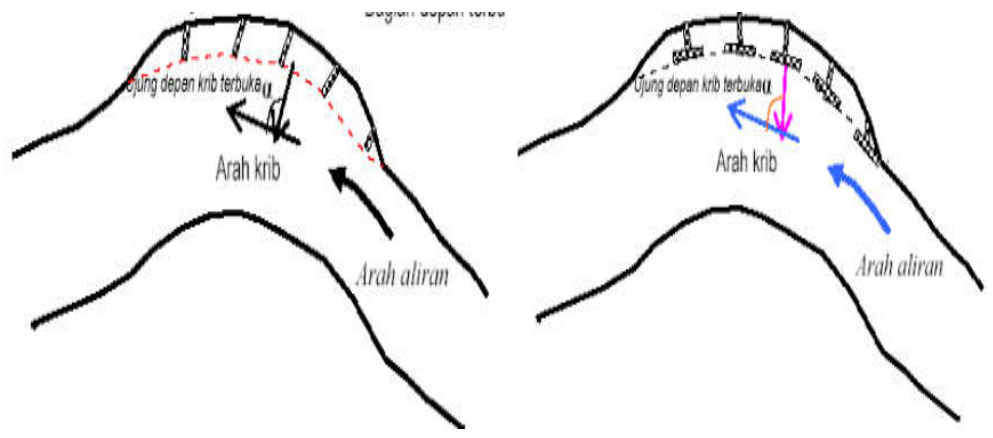

Gambar 4-16. Krib pada sungai

C. Ambang (Groundsill)

Ambang/ drempel (groundsill) adalah bangunan melintang badan sungai untuk menghindari perbedaan elevasi dasar sungai yang berlebihan.

Pada pekerjaan sudetan, dasar sungai bagian hulu akan turun. Untuk itu biasanya dilengkapi dengan penempatan ambang di hulu sudetan. Selain itu, ambang juga digunakan untuk menstabilkan kemiringan sungai agar tidak terlalu curam

Konstruksi ambang biasanya terdiri atas:

- Bangunan utama

- Pondasi ambang

- Lantai muka

- Sayap ambang

- Perkuatan sayap 

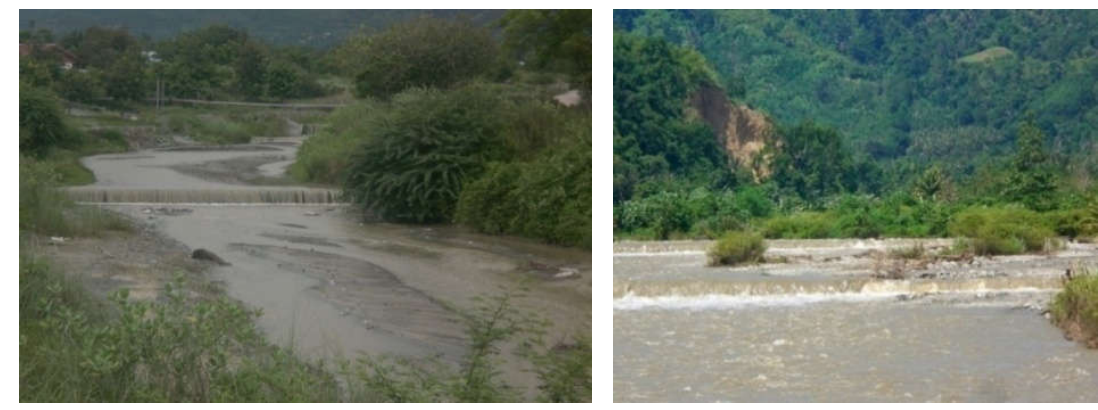

Gambar 4-17. Ambang sungai (Groundsill)

Bendung adalah bangunan yang dipasang melintang ditengah sungai yang fungsi utamanya untuk meninggikan muka air,juga dapat berfungsi untuk 1) pembagi banjir, 2) penahan air pasang, 3) penyadap.

Kaidah Disain bendung yang sudah berlaku: Harus aman terhadap guling dan terhadap gelincir.

Bagian-bagian Konstruksi bendung:

- Bangunan utama,

- Pondasi ambang,

- Lantai muka,

- Sayap ambang dan

- Perkuatan sayap

\section{Soal Latihan 2}

1. Uraikan proses terbentuknya sungai bermeander dan braided dan apakah hubungannya dengan sistem pengaliran di sungai? 
2. Uraikan upaya-upaya pencegahan dari rusaknya tanggulsungai akibat gerusan dan longsor pada tebing?

3. Uraikan fungsi-fungsi bangunan utama persungaian dan dalam kondisi apa bangunan tersebut di gunakan?

4. Uraikan bangunan pengendali banjir pada sungai dan bagaimana meminimalisi dampak dari banjir tersebut?

5. Dalam kondisi sungai yang berbelok-belok, apa pandangan saudara terhadap sungai yang berkelok-kelok tersebut.

6. Uraikan manfaat groundsil dan dalam kondisi apa, bangunan tersebut dibangun?. 


\section{MODUL 5. SALURAN TERBUKA}

1. Sasaran Pembelajaran

- Mahasiswa dapat mengetahui serta memahami klasifikasi aliran, persamaan aliran, saluran terbuka dan tampang ekonopmis

- Mahasiswa dapat mengetahui aliran pada saluran terbuka dan kesepatan maksimum yang di izinkan.

2. Kemampuan yang mahasiswa yang menjadi prasyarat Hidrolika, Hidrologi dan pengembangan sumber daya air.

3. Keterkaitan bahan pembelajaran dengan pokok bahasan lainnya sangat berkaitan dan merupakan satu kesatuan yang saling menunjang

4. Manfaat atau pentingnya bahan pembelajaran ini yaitu mahasiswa mampu memahami karakteristik alairan dan aliran melaluipenampang terbuka.

5. Petunjuk belajar mahasiswa, penjelasan tentang hal hal yang perlu dilakukan mahasiswa dalam mempelajari materi ini yaitu dengan menampilkan beberapa contoh dan gambar serta memberi tugas mencari paper di internet sehingga akan memperkaya wawasan mereka.

\subsection{Aliran pada Saluran Terbuka}

Sifat aliran pada saluran terbuka berbeda dengan aliran air saluran tertutup yaitu : 1) aliran air pada saluran terbuka memiliki permukaan bebas("free surface"), 2) tekanan air pada permukaan bebas, sama dengan tekanan atmosfir, dan 3) terjadinya saling tergantung antara jari-jari tampang basah, 
kekentalan zat cair, kemiringan dasar saluran, kekasaran dasar, danbervariasinya geometrik saluran.

Pada saluran terbuka aliran hanya mempunyai bidang kontak pada dinding dan dasar saluran. Saluran terbuka dapat berupa: Saluran alamiah atau buatan, dan Galian tanah dengan atau tanpa lapisan penahan.

Beberapa bentuk bentuk saluran terbuka dapat dilihat pada Gambar 3.1 berikut:

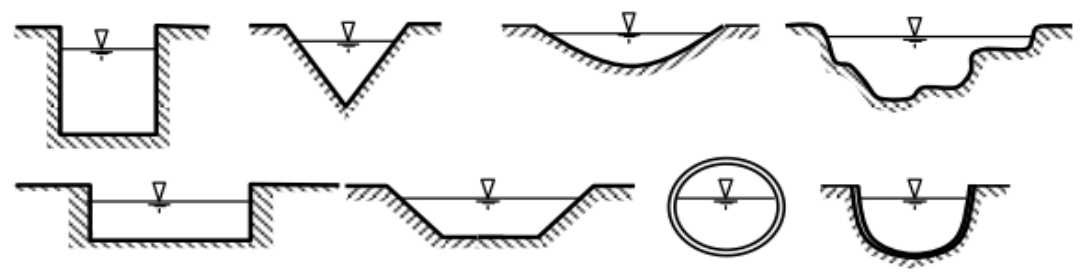

Gambar 5-1. Bentuk potongan melintang saluran

5.2 Klasifikasi Aliran Saluran Terbuka dan Pengelompokan Aliran

Sifat aliran pada saluran terbuka pada umumnya menggunakan parameter yang berdasar atas perubahan kedalaman alirandengan fungsi waktu dan ruang. Aliran dibedakan menjadi aliran tunak (steady) dan tak tunak (unsteady). Berdasarkan fungsi ruang, aliran dibedakan menjadi aliran seragam (uniform)dan tidak seragam (non-uniform).

Pengelompokan aliran berdasarkan gaya kekentalan (viscous forces) dijabarkan oleh Reynolds $\left(\mathrm{R}_{\mathrm{e}}\right)$, 


$$
R e=\frac{\rho \frac{\mathrm{U}^{2}}{\mathrm{~L}}}{\mu \frac{\mathrm{U}}{\mathrm{L}^{2}}}=\frac{\mathrm{UL}}{v}
$$

Dengan: $\rho \frac{\mathrm{u}^{2}}{\mathrm{~L}}=$ Gaya enersia, $\mu \frac{\mathrm{u}}{\mathrm{L}^{2}}=$ Gaya gaya geser terhadap dasar.

Menurut Chow (1989), nilai Re untuk saluran terbuka $R_{e} \leq$ 500 disebut aliran berlapis (laminer flow), $\mathrm{Re} \geq 2000$ disebut aliran bergolak (turbulent flow), 500 $<\mathrm{R}_{\mathrm{e}}<2000$ disebut aliran transisi. Nilai Re untuk saluran tertutup pipa: $R_{e} \leq 2.000$ disebut aliran berlapir (laminer flow), $\mathrm{R}_{\mathrm{e}} \geq 10.000$ disebut aliran bergolak (turbulent flow), $2.000<\mathrm{R}_{\mathrm{e}}<10.000$ disebut aliran transisi.

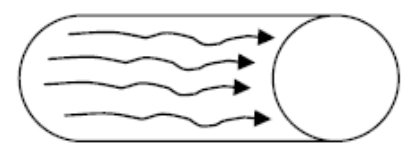

Aliran laminar

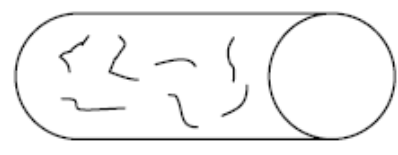

Aliran turbulen

Pengelompokan aliran berdasarkan gaya gravitasi dijabarkan Froude $\left(F_{r}\right)$ dengan suatu bilangan tak berdimensi

$$
\mathrm{F}_{\mathrm{r}}=\frac{\mathrm{u}}{\sqrt{\mathrm{gD}}}
$$

Dengan: $\mathrm{u}=$ Kecepatan rata-rata aliran, $\mathrm{g}=$ Gaya gravitasi, $\mathrm{D}=$ Kedalaman maksimum aliran

Bila $\mathrm{F}_{\mathrm{r}}<1$, artinya $\mathrm{u}<\sqrt{\mathrm{gD}}=$ aliran sub kritis

Bila $\mathrm{F}_{\mathrm{r}}>1$, artinya $\mathrm{u}>\sqrt{\mathrm{gD}}=$ aliran super kritis

Bila $F_{r}=1$ artinya $u=\sqrt{g D}=$ aliran kritis 
Mengacu pada batasan untuk saluran terbuka menurut Chow (1989), dapat disimpulkan bahwa hubungan antara aliran berdasarkan kekentalan dan aliran berdasarkan gaya gravitasi $\left(R_{e}\right.$ dan $\left.F_{r}\right)$ untuk saluran terbuka sebagai Tabel 5-1.

Tabel 5-1. Pengelompokan aliran berdasarkan bilangan Froude dan Reynolds pada saluran terbuka

\begin{tabular}{llcc}
\hline No. & \multicolumn{1}{c}{ Pengelompokan } & $\begin{array}{c}\text { Bilangan } \\
\text { Froude } \\
\left(\mathrm{F}_{\mathrm{r}}\right)\end{array}$ & $\begin{array}{c}\text { Bilangan } \\
\text { Reynolds }\left(\mathrm{R}_{\mathrm{e}}\right)\end{array}$ \\
\hline 1 & Aliran sub keritis - berlapis & $<1$ & $<500$ \\
2 & Aliran superkritis - berlapis & $>1$ & $<500$ \\
3 & Aliran sub kritis - transisi & $<1$ & $500<\mathrm{Re}<2000$ \\
4 & Aliran super kritis - transisi & $>1$ & $500<\mathrm{Re}<2000$ \\
5 & Aliran kritis & $=1$ & Bebas \\
6 & Aliran sub kritis - bergolak & $<1$ & $>2000$ \\
7 & Aliran super kritis - bergolak & $>1$ & $>2000$ \\
\hline
\end{tabular}

\subsection{Persamaan Aliran}

Untuk menganalisis aliran dapat digunakan beberapa persamaan dasar aliran untuk menyelesaikan permasalahan hidrolika yaitu : 1) hukum Persamaan Kontinuitas; 2) hukum Persamaan Energi; 3) hukum Persamaam Momentum.

Persamaan kontinuitas didasarkan pada hukum konservasi masa. maka dapat diturunkan persamaan kontinyuitas sebagai berikut:

$\left[\left(Q \quad \frac{\partial Q}{\partial X} \cdot \frac{X}{2}\right)\left(Q+\frac{\partial Q}{\partial X} \cdot \frac{X}{2}\right)\right] . t=\frac{\partial Q}{\partial X} \quad X . \partial$

Atau : 


$$
Q=A_{1} \cdot V_{1}=A_{2}, V_{2}
$$

Hukum persamaan energi menggunkan hukum Bernoulli dimana dinyatakan bahwa jumlah energi air dari setiap aliran yang melalui suatu penampang saluran, dapat dinyatakan sebagai jumlah fungsi air, tinggi tekanan dan tinggi kecepatan.

$$
H=z+d \cos \theta+\frac{V^{2}}{2 g}
$$

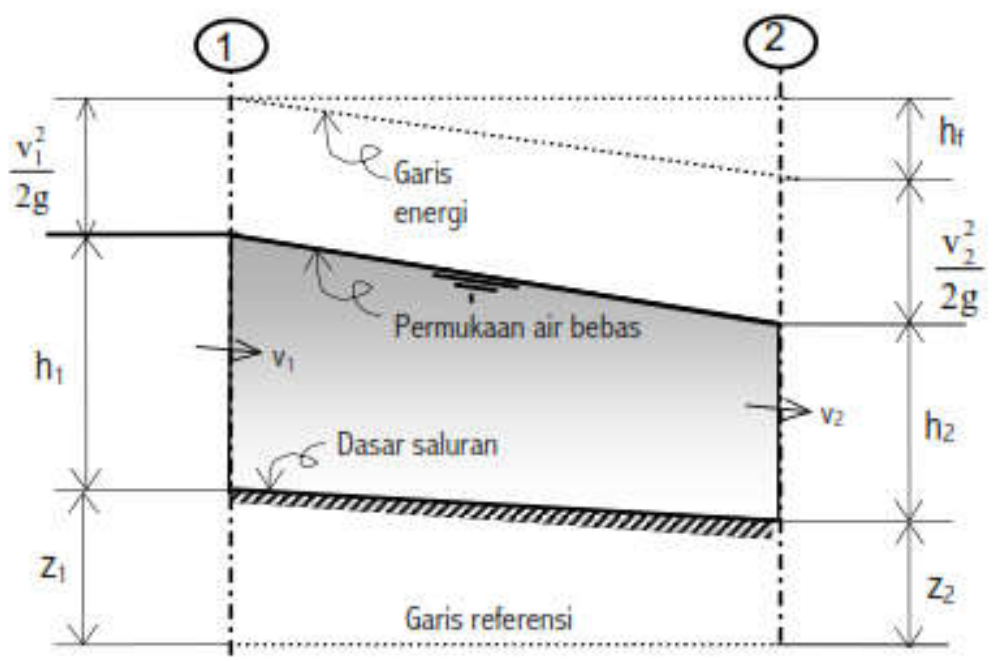

Gambar 5-2.Persamaan energi pada saluran terbuka

Menurut prinsip kekekalan energi, jumlah tinggi fungsi energi pada penampang 1 di hulu akan sama dengan jumlah fungsi energi pada penampang 2 di hilir dan fungsi hf diantara kedua penampang tersebut.

$$
\mathrm{H}=\mathrm{z}_{1}+\mathrm{d}_{1} \cos \theta+\alpha_{1} \frac{\mathrm{V}_{1}^{2}}{\mathrm{~g}}=\mathrm{z}_{2}+\mathrm{d}_{2} \cos \theta+\alpha_{2} \frac{\mathrm{V}_{2}^{2}}{\mathrm{~g}}+\mathrm{h}_{\mathrm{f}} \quad 5.6
$$


Untuk saluran yang kemiringannya kecil, $0 \approx \theta$, persamaan (3-14) menjadi :

$$
\mathrm{z}_{1}+\mathrm{h}_{1}+\frac{\mathrm{V}_{1}^{2}}{\mathrm{~g}}=\mathrm{z}_{2}+\mathrm{h}_{2}+\frac{\mathrm{V}_{2}{ }^{2}}{\mathrm{~g}}+\mathrm{h}_{\mathrm{f}}
$$

dimana :

$$
\begin{aligned}
& \mathrm{z}=\text { fungsi titik diatas garis referensi, } \\
& \mathrm{h}=\text { fungsi tekanan di suatu titik, } \\
& \mathrm{v}=\text { kecepatan aliran, } \\
& \mathrm{g}=\text { gaya gravitasi bumi. }
\end{aligned}
$$

Hukum persamaan momentum mengikuti hukum Newton kedua tentang gerakan, menyatakan bahwa besarnya perubahan momentum persatuan waktu pada suatu persamaan adalah sama dengan besarnya resultante semua gaya-gaya yang bekerja pada pias tersebut.

$$
\sum F=P Q \cdot V
$$

Berdasar Gambar 5-3, maka persamaan konservasi momentum tersebut dapat ditulis sebagai:

$$
\mathrm{P}_{1}+\mathrm{P}_{2}+\mathrm{W} \sin \theta \quad \mathrm{F}_{\mathrm{f}} \quad \mathrm{F}_{\mathrm{a}}=\mathrm{PQ}\left(\mathrm{V}_{2} \quad \mathrm{~V}_{1}\right)
$$

dimana :

$$
\begin{aligned}
\mathrm{P}= & \text { tekanan hidrostatis } \\
\mathrm{W}= & \text { berat volume pada pias }(1)-(2) \\
\mathrm{S}_{\mathrm{o}}= & \text { kemiringan dasar saluran } \\
\mathrm{F}_{\mathrm{a}}= & \text { tekanan udara pada muka air bebas } \\
\mathrm{F}_{\mathrm{f}}= & \text { gaya geser yang terjadi akibat kekasaran } \\
& \text { dasar. }
\end{aligned}
$$




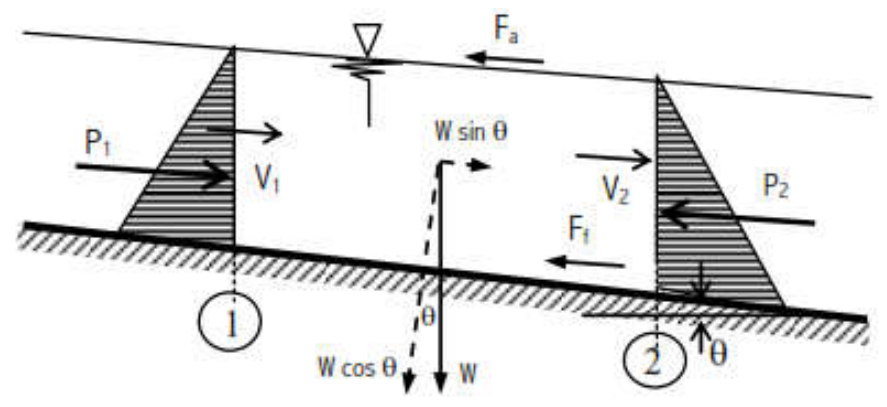

Gambar 5-3. Penerapan dalil momentum

\subsection{Saluran Terbuka}

Padasaluran terbuka, kondisi aliran dalam kedudukan permukaan bebas dan cenderung berubah menurut ruang dan waktu. Hubungan ketergantungan antara kedalaman aliran, debit air, kemiringan dasar saluran dan permukaan bebas. Air mengalir dari tempat yang tinggi ke tempat yang rendah dan prinsip gravitasi sangat berpengaruh karena adanya perbedaan elevasi antara hulu dan hilir. Gejala dasar aliran fluida dapat diketegorikan sebagai berikut :

1) Aliran berlapis (Laminar)

Aliran dengan fluida yang bergerak dalam lapisan-lapisan, atau lamina-lamina dengan satu lapisan meluncur secara lancer.Aliran pada saluran terbuka dikatakan laminar apabila gaya kekentalan (viscosity) relatif sangat besar dibandingkan dengan gaya inersia sehingga kekentalan berpengaruh besar terhadap perilaku aliran. Butir-butir air bergerakmenurut lintasan tertentu yang teratur atau lurus. 
2) Aliran Bergolak (turbulent)

Aliran dalam saluran terbuka dikatakan turbulen apabila gaya kekentalan relatif lemah dibandingkan dengan gaya inersia. Butir-butir air bergerak menurut lintasan yang tidak teratur, tidak lancer, tidak tetap, walaupun tetap bergerak maju di dalam air yang berjalan secara keseluruhan. Aliran ini terlihat bergoncang (turbulensi). Aliran turbulen itu sangatbertolak belakang dengan aliran laminar. Jika pada suatu kelajuan tertentu ada partikel-partikel (butir-butir air) gerakannya berbeda dan bahkan berlawanan dengan arah gerak keseluruhan itu dinamakan aliran turbulen.

3) Aliran Transisi

Beberapa penulis mengelompokkan aliran dengan nilai yang berbeda: Aliran peralihan dari aliran laminar ke aliran turbulen atau sebaliknya atau dapat dibedakan dengan menggunakan bilangan Reynolds dimana kecepatan aliran dibedakan sebagai berikut : 1) Aliran laminar, dengan $\mathrm{R}_{\mathrm{e}}<$ 2300; 2) Aliran turbulen, dengan $\mathrm{R}_{\mathrm{e}}>$ 4000; 3) Aliran transisi, dengan $R_{e}$ diantara 2300 dan 4000 (bilangan Reynolds kritis).

Suatu saluran terbuka cenderung memiliki penampang berubah-rubah, namun untuk kondisi saluran melintangnya tidak berubah-berubah dan kemiringan dasar tetap disebut saluran prismatic. Demikian pula Bila sebaliknya, disebut nonprismatic channel. 


\subsection{Aliran Melalui Penampang}

Untuk menghitung dimensi penampang saluran dengan analisis hidraulika bertujuan untuk mendapatkan penampang efisiens. Ukuran penampang terbaik dimaksudkan adar tidak mengakibatkan erosi maupun tidak mengakibatkan endapan sedimen. Adapun persamaan perhitungan dimensi saluran menggunakan persamaan

\section{1) Rumus Chezy}

Pada saluran terbuka untuk mengetahui kecepatan aliran dapat dilakukan dengan dengan berbagai macam pilihan rumus empriris, hal disebabkan banyaknya variabel yang berubah-ubah. Sebagai contoh rumus Chezy dengan persamaan umum:

$$
C=\frac{1}{n} R^{1 / 6}
$$

dimana:

$$
\begin{aligned}
& \mathrm{V}=\text { kecepatan aliran (velocity), (m/det) } \\
& \mathrm{R}=\text { jari-jari hidraulik (radius), }(\mathrm{m}) \\
& \mathrm{S}=\text { kemiringan saluran (slope of energy) } \\
& \mathrm{C}=\text { koefisien Chezy }
\end{aligned}
$$

Beberapa ahli telah mengusulkan beberapa bentuk koefisien Chezy dari rumus umum tersebut yang tergantung dari bentuk tampang lintang, bahan dinding saluran, dan kecepatan aliran. Untuk itu dapat ditinjau beberapa rumus yang banyak digunakan. 
2) Rumus Robert Manning

Persaman perhitungan dimensi saluran dengan rumus Manning yaitu :

$$
C=\frac{1}{n} R^{1 / 6}
$$

Rumus kecepatan aliran menjadi:

$$
V=\frac{1}{n} R^{2 / 3} S^{1 / 2}
$$

Nilai kekasaran Manning (n) merupakan fungsi dari jenis bahan dinding saluran. Nilai koefisien Manning sebagai contoh pada tabel 5-2 dan masih banyak lagi koefisien lainnya yang belum dicantumkan disini,

Tabel 5-2. Nilai koefisien Manning

\begin{tabular}{|l|c|}
\hline \multicolumn{1}{|c|}{ Bahan } & $\begin{array}{c}\text { Koefisien } \\
\text { Manning } \\
n\end{array}$ \\
\hline Besi tuang dilapis & 0,014 \\
Kaca & 0,010 \\
Saluran beton & 0,013 \\
Bata dilapis Mortar & 0,015 \\
Pasangan batu disemen & 0,025 \\
Saluran tanah bersih & 0,022 \\
Saluran tanah & 0,030 \\
Saluran dengan dasar batu dan tebing rumput & 0,040 \\
Saluran pada galian batu padas & 0,040 \\
\hline
\end{tabular}


3) Rumus Strickler

Untuk Menghitung dengan persamaan strickler harus diketahui koefisien Strickler $\left(\mathrm{k}_{\mathrm{s}}\right)$ dengan rumus berikut:

$$
k_{s}=\frac{1}{n}=26\left(\frac{R}{d_{35}}\right)^{1 / 6}
$$

Dengan $\mathrm{R}$ adalah jari-jari hidraulik, dan $\mathrm{d}_{35}$ adalah diameter (dalam meter).Rumus kecepatan diperoleh dengan menggunakan koefisien tersebut, sehingga persamaan kecepatan aliran menjadi:

$$
V=k_{s} R^{2 / 3} S^{1 / 2}
$$

\section{Contoh Soal:}

Diketahui suatu saluran terbuka terbuat dari pasangan batu berbentuk segi empat jika kemiringan dasar saluran adalah 0,00015 dengan $n=0,025$ dan lebar $10 \mathrm{~m}$, jika 3 $\mathrm{m}$ diketahui sebagai kedalaman air. Maka hitunglah debit aliran pada saluran terbuka tersebut.

Solusi :

Luaspenampang basah:

$\mathrm{A}=\mathrm{B} \times \mathrm{h}$

$=3 \times 10=30 \mathrm{~m}^{2}$

Maka Keliling basah adalah :

$\mathrm{P}=\mathrm{B}+2 \mathrm{~h}$

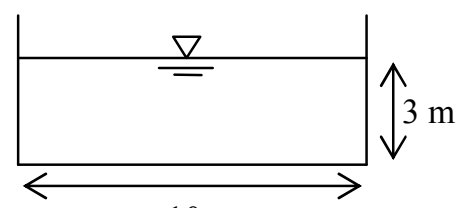

$10 \mathrm{~m}$

$=10+2 \times 3=16 \mathrm{~m}$

Menghitung Jari-jari hidraulis sebagai berikut : 


$$
\begin{aligned}
R & =\frac{A}{P} \\
R & =\frac{30}{16}=1,875 m
\end{aligned}
$$

Menghitung debit aliran dengan menggunakan rumus Manning:

$$
\begin{aligned}
& Q=A \cdot V \\
& Q=A \cdot \frac{1}{n} R^{2 / 3} S^{1 / 2} \\
& Q=30 \cdot \frac{1}{0,025} 1,875^{2 / 3} 0,00015^{1 / 2}=22,347 \mathrm{~m}^{3} / \operatorname{det}
\end{aligned}
$$

\section{Contoh Soal:}

Tentukan kedalaman air apabila energi spesifiknya minimum (kedalaman kritis), dan kecepatan kritisnya jika saluran dengan lebar $5 \mathrm{~m}$ mengalirkan air dengan debit $15 \mathrm{~m}^{3} /$ det.

Penyelesaian:

Debit tiap satuan lebar:

$$
q=\frac{Q}{B}=\frac{15}{5}=3 \mathrm{~m}^{3} / \mathrm{d} / \mathrm{m}
$$

Kedalaman air'kritis:

$$
y_{c}=\sqrt[3]{\frac{q^{2}}{g}}=\sqrt[3]{\frac{3^{2}}{9,81}}=0,972 m
$$

Kecepatan kritis:

$$
v_{c}=\frac{q}{y_{c}}=\frac{3}{0,972}=3,087 \mathrm{~m} / \mathrm{det}
$$

\subsection{Tampang Ekonomis}

Prinsip saluran tampang ekonomis hanya berlaku untuk desain saluran yang tahan terhadap erosi. Suatu tampang lintang 
saluran akan menghasilkan debit maksimum bila nilai $\mathrm{R}=\mathrm{A} / \mathrm{P}$ maksimum atau keliling basah P minimum, sehingga untuk debit tertentu, luas tampang lintang akan minimum (ekonomis). Tabel berikut memperlihatkan tipe bentuk saluran ekonomis dan karakteristiknya.

Tabel 5-3. Tipe dan bentuk penampang saluran ekonomis

\begin{tabular}{|l|c|c|c|c|c|c|}
\hline \multicolumn{1}{|c|}{$\begin{array}{c}\text { Penampang } \\
\text { melintang }\end{array}$} & Luas & $\begin{array}{c}\text { Keliling } \\
\text { basah } \\
\mathrm{P}\end{array}$ & $\begin{array}{c}\text { Jari-jari } \\
\text { hidraulik } \\
\mathrm{R}\end{array}$ & $\begin{array}{c}\text { Lebar } \\
\text { puncak } \\
\mathrm{T}\end{array}$ & $\begin{array}{c}\text { Kedalaman } \\
\text { hidraulik } \\
\mathrm{D}\end{array}$ & $\begin{array}{c}\text { Faktor } \\
\text { penampang } \\
\mathrm{Z}\end{array}$ \\
\hline $\begin{array}{l}\text { Trapesium, } \\
\text { setengah bagian } \\
\text { segi enam } \\
\begin{array}{l}\text { Persegi panjang, } \\
\text { setengah bagian } \\
\text { bujur sangkar } \\
\text { Segitiga, setengah } \\
\text { bagian bujur } \\
\text { sangkar }\end{array}\end{array}$ & $2 y^{2}$ & $4 y$ & $1 / 2 y$ & $4 / 3 \sqrt{3} y$ & $3 / 4 y$ & $3 / 2 y^{2,5}$ \\
$\begin{array}{l}\text { Setengah } \\
\text { lingkaran }\end{array}$ & $\frac{2 \sqrt{3} y}{2} y^{2}$ & $2 \sqrt{2} y$ & $1 / 4 \sqrt{2} y$ & $2 y$ & $1 / 2 y$ & $\frac{\sqrt{2}}{2} y^{2,5}$ \\
$\begin{array}{l}\text { Parabola } \\
\text { Lengkung } \\
\text { hidrostatis }\end{array}$ & $4 / 3 \sqrt{2} y^{2}$ & $8 / 3 \sqrt{2} y$ & $1 / 2 y$ & $2 \sqrt{2} y$ & $2 / 3 y$ & $\frac{\pi}{4} y^{2,5}$ \\
\hline
\end{tabular}

Sumber: Chow, 1992

Contoh soal:

Desain suatu dimensi saluran bentuk trapesium dengan kemiringan tebing $1: 2$ dimana aliran sebesaar $40 \mathrm{~m}^{3} /$ detik, jika kecepatan rata-rata $0,8 \mathrm{~m} /$ detik dan $\mathrm{C}=50 \mathrm{~m}^{1 / 2} / \mathrm{d}$. Berapakah kemiringan dasar saluran ekonomis?

Solusi:

Luas penampang aliran:

$$
A=\sqrt{3} y^{2}
$$

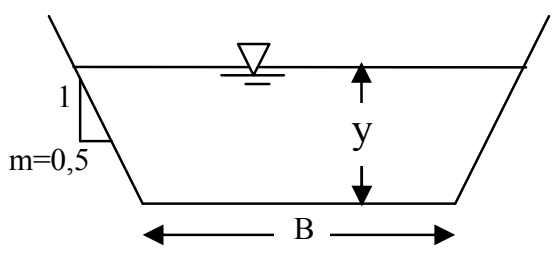

5-13 
Dengan persmaan kontinuitas dihitung luas penampang aliran :

$A=\frac{Q}{V}=\frac{40}{0,8}=50 \mathrm{~m}^{2}$

Sehingga didapatkan:

$y=\sqrt{\frac{A}{\sqrt{3}}}=5,37 \mathrm{~m}$

Persamaan luas penampang trapesium:

$A=(B+m y) y$

Lebar dasar saluran adalah:

$B=\frac{A}{y}-m y=\frac{50}{5,37}-0,5.5,37=6,63 m$

Sehingga diperoleh kemiringan dasar saluran ekonomis.

$$
R=\frac{y}{2}=\frac{5,37}{2}=2,685 \mathrm{~m}
$$

Dengan menggunakan rumus Chezy diperoleh :

$U=C \sqrt{R S}$

$0,8=50 \sqrt{2,685 \cdot S}$

$S=9,534 \cdot 10^{-5}$

5.7 Kecepatan Maksimum yang Diizinkan

Untuk mencegah erosi pada suatu saluran maka perlu ditetapkan kecepatan maksimum yang diijinkan. Besarnya kecepatan bervariasi sehingga perlu direncanakan kecepatan rerata tanpa menimbulkan erosi. Tabel 5-4 memberikan kecepatan maksimum yang diijinkan disaluran menurut beberapa hasil penelitian. 
Tabel 5-4. Kecepatan maksimum yang diijinkan menurut Fortier dan Scobey

(Untuk Saluran lama, lurus, dengan kemiringan kecil)

\begin{tabular}{|l|c|c|c|c|c|}
\hline \multirow{2}{*}{ Bahan } & \multirow{2}{*}{$\mathrm{n}$} & \multicolumn{2}{|c|}{ Air Jernih } & \multicolumn{2}{c|}{$\begin{array}{c}\text { Air mengandung } \\
\text { koloida lanau }\end{array}$} \\
\cline { 3 - 7 } & & $\begin{array}{c}\mathrm{v} \\
(\mathrm{ft} / \mathrm{sec})\end{array}$ & $\begin{array}{c}\mathrm{v} \\
(\mathrm{m} / \mathrm{det})\end{array}$ & $\begin{array}{c}\mathrm{v} \\
(\mathrm{ft} / \mathrm{sec})\end{array}$ & $\mathrm{v}$ (m/det) \\
\hline Pasir halus, koloida & 0.020 & 1.50 & 0.46 & 2.50 & 0.76 \\
\hline Lanau berpasir, bukan koloida & 0.020 & 1.75 & 0.53 & 2.50 & 0.76 \\
\hline Lanau bukan koloida & 0.020 & 2.00 & 0.61 & 3.00 & 0.91 \\
\hline Lanau aluvial, bukan koloida & 0.020 & 2.00 & 0.61 & 3.50 & 1.07 \\
\hline Lanau kaku biasa & 0.020 & 2.50 & 0.76 & 3.50 & 1.07 \\
\hline Debu vulkanis & 0.020 & 2.50 & 0.76 & 3.50 & 1.07 \\
\hline Lempung teguh, koloida kuat & 0.025 & 3.75 & 1.14 & 5.00 & 1.52 \\
\hline Lanau aluvial, koloida & 0.025 & 3.75 & 1.14 & 5.00 & 1.52 \\
\hline Serpih dan diulangkan keras & 0.025 & 6.00 & 1.83 & 6.00 & 1.83 \\
\hline Kerikil halus & 0.020 & 2.50 & 0.76 & 5.00 & 1.52 \\
\hline $\begin{array}{l}\text { Lanau bergradasi sampai kerakal, bukan } \\
\text { koloida }\end{array}$ & 0.030 & 3.75 & 1.14 & 5.00 & 1.52 \\
\hline Lanau bergradasi sampai kerakal, koloida & 0.030 & 4.00 & 1.22 & 5.50 & 1.68 \\
\hline Kerikil kasar, bukan koloida & 0.025 & 4.00 & 1.22 & 6.00 & 1.83 \\
\hline Kerakal dan batuan bulat & 0.035 & 5.00 & 1.52 & 5.50 & 1.68 \\
\hline
\end{tabular}

Prosedur perhitungan kecepatan yang diizinkan adalah sebagai berikut:

a. Menentukan nilai $\mathrm{n}$ berdasarkan jenis bahan dinding saluran, dan menentukan kemiringan dasar saluran, dan kecepatan maksimum yang diijinkan berdasarkan Tabel 54.

b. Menghitung jari-jari hidraulik $\mathrm{R}$ dengan menggunakan rumus Manning.

c. Menghitung luas basah dengan debit yang diketahui dan kecepatan yang diijinkan menggunakan persamaan $A=Q / V$

d.Menghitung keliling basah dengan menggunakan persamaan $P=A / R$. 
Tambahkan jagaan seperlunya, dan mempertimbangkan kepraktisan dalam pembuatan saluran.

\section{Soal Latihan 3}

1. Uraikan tahapan desain untuk pekerjaan normalisasi sungai?

2. Untuk perencanaan saluran sungai, apa saja yang menjadi perhatian utama?

3. Uraikan langkah penentuan dimensi efektif dan ekonomis jika di ketahui debit yang akan di alirkan adalan $120 \mathrm{~m} 3 / \mathrm{det}$ dan lebar existing sungai adalah $60 \mathrm{~m}$ ?

4. Uraikan dalam kondisi bagaimana terjadi aliran kritis dan sub kritis pada penampang sungai? 


\section{MODUL 6. ALIRAN PADA BELOKAN SALURAN}

1. Sasaran Pembelajaran

- Mahasiswa dapat mengetahui serta memahami gerusan padabelokan sungai

- Mahasiswa dapat mengetahui superelevasi dan distribusi kecepatan padabelokan sungai.

2. Kemampuan yang mahasiswa yang menjadi prasyarat Hidrolika, Hidrologi dan pengembangan sumber daya air.

3. Keterkaitan bahan pembelajaran dengan pokok bahasan lainnya sangat berkaitan dan merupakan satu kesatuan yang saling menunjang

4. Manfaat atau pentingnya bahan pembelajaran ini yaitu mahasiswa mampu memahami gerusan dan distribusi kecepatan padabelokan sungai.

5. Petunjuk belajar mahasiswa, penjelasan tentang hal hal yang perlu dilakukan mahasiswa dalam mempelajari materi ini yaitu dengan menampilkan beberapa contoh dan gambar serta memberi tugas mencari paper di internet sehingga akan memperkaya wawasan mereka.

\subsection{Gerusan pada Belokan Saluran}

Mozaffari dkk. (2011) melakukan penelitian dengan menitik beratkan pada adanya arus sekunder yang berhubungan dengan dasar saluran pada belokan sungai yang sangat berpengaruh terhadap distribusi kecepatan dalam arah vertikal dan arah melintang, yang menyebabkan tegangan geser dalam melintang dan memanjang pada belokan. Penelitian dengan menggunakan satu set saluran buatan untuk menelusuri 
distribusi kecepatan dalam arah melintang dan memanjang saluran pada belokan saluran, dan dilakukan di laboratory of hydraulics departement of EPFL University in Switzerland, dengan menggunakan debit 63, 89, dan 104 ltr/dt. Dengan dimensi saluran lebar 1,3 m, sudut belokan 193 derajat, pengambilan data dilakukan mulai pada Januari 2009 sampai dengan bulan September 2009, pengukuran kecepatan dengan menggunakan alat Acoustic Doppler Velocimeter Profiler(ADVP)

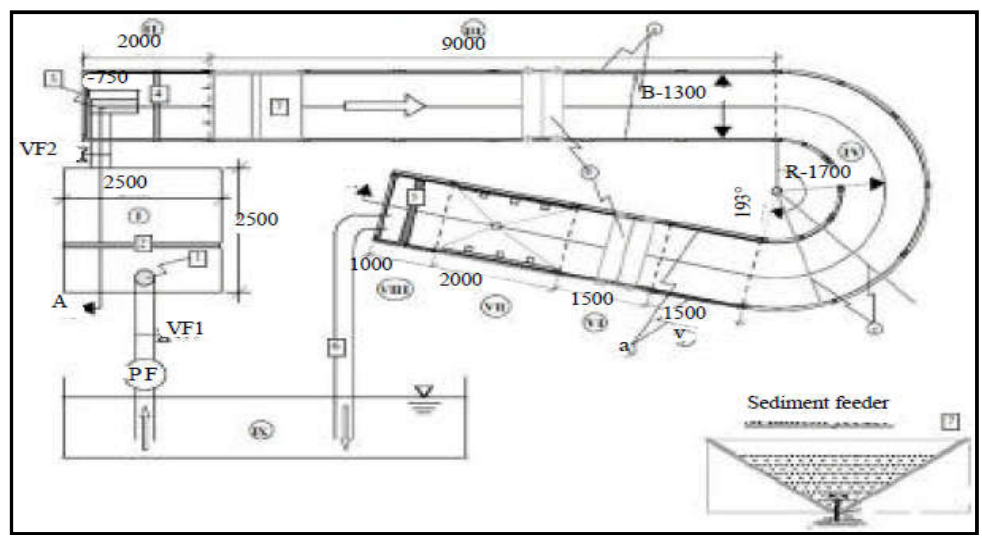

Gambar 6-1.Model saluran penelitian (Mozaffari dkk., 2011)

Gambar tersebut di atas memperlihatkan sirkulasi dimana bak sebagai sumber air untuk dialirkan ke saluran, yang bermula pada saluran lurus dengan panjang $9 \mathrm{~m}$, kemudian memasuki belokan saluran dengan jari-jari 1,7 m, pada hilir pertama saluran dengan panjang $3 \mathrm{~m}$, dan selanjutnya dengan saluran 2 m menuju pada bak penampung sedimen. 
Tabel 6-1. Besaran aliran dan dimensi saluran model Mozaffari dkk. (2011)

\begin{tabular}{|c|c|c|c|c|c|c|c|c|c|}
\hline $\mathbf{Q}$ & $\mathbf{H}$ & $\mathbf{u}$ & $\mathbf{u}_{*}$ & $\mathbf{S}_{\mathbf{f}}$ & $\mathbf{R}_{\mathbf{e}}$ & $\mathbf{F}_{\mathbf{r}}$ & $\mathbf{R} / \mathbf{B}$ & $\mathbf{R} / \mathbf{H}$ & $\mathbf{B} / \mathbf{H}$ \\
{$[\mathrm{l} / \mathrm{dt}$} & $\mathrm{m}$ & $\mathrm{m} / \mathrm{dt}$ & $\mathrm{m} / \mathrm{dt}$ & {$[-]$} & {$[-]$} & {$[-]$} & {$[-]$} & {$[-]$} & {$[-]$} \\
\hline 63 & 0,098 & 0,49 & 0,056 & 0,004 & 43000 & 0,5 & 1,31 & 17 & 13 \\
89 & 0,12 & 0,54 & 0,063 & 0,0037 & 58000 & 0,5 & 1,31 & 14,1 & 10,8 \\
104 & 0,13 & 0,63 & 0,065 & 0,0043 & 73000 & 0,56 & 1,31 & 13 & 10 \\
\hline
\end{tabular}
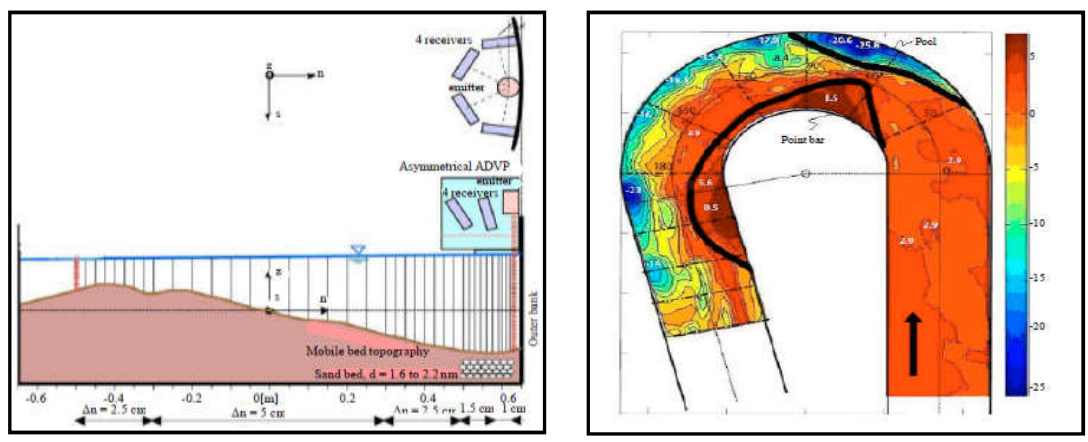

Gambar 6-2.Potongan melintang permukaansedimen pada sudut belokan $70^{\circ}$ dan topografi aliran untuk debit 63 1t/dt (Mozaffari dkk., 2011)

Pada gambar 6-2 menunjukkan perubahan topografi untuk debit 63 ltr/dt dengan gerusan maksimum pada bagian luar belokan saluran, dan pada bagian dalam belokan saluran terjadi pendangkalan, diperlihatkan juga adanya gerusan pada 6 titik, yang terdalam pada bagian luar belokan di sudut $70^{\circ}$. Kemiringan dasar saluran mulai pada sudut $31^{0}$, dan gerusan mulai menurun setelah sudut belokan $90^{\circ}$.

Penelitian lainnya yang dilakukan oleh Blanckaert (2002) dengan dimensi hidrolis pada tabel dibawah ini: 
Tabel 6-2. Dimensi hidrolis model (Blanckaert 2002)

\begin{tabular}{|c|c|c|c|c|c|c|c|c|c|c|}
\hline $\begin{array}{c}\mathrm{R} \\
{[\mathrm{m}]}\end{array}$ & $\begin{array}{c}\mathrm{B} \\
{[\mathrm{m}]}\end{array}$ & $\begin{array}{c}\mathrm{Q} \\
{[\mathrm{lt} / \mathrm{dt}]}\end{array}$ & $\begin{array}{c}\mathrm{S}_{\mathrm{s}} \\
{[\mathrm{o} / \mathrm{oo}]}\end{array}$ & $\begin{array}{c}\mathrm{u} \\
{[\mathrm{m} / \mathrm{dt}]}\end{array}$ & $\begin{array}{c}\mathrm{C} \\
{\left[\mathrm{m}^{1 / 2} / \mathrm{dt}\right]}\end{array}$ & $\begin{array}{c}\mathrm{R}_{\mathrm{e}} \\
{\left[10^{3}\right]}\end{array}$ & $\begin{array}{c}\mathrm{F}_{\mathrm{r}} \\
{[-]}\end{array}$ & $\begin{array}{c}\mathrm{R} / \\
\mathrm{B} \\
{[-]}\end{array}$ & $\begin{array}{c}\mathrm{R} / \mathrm{H} \\
{[-]}\end{array}$ & $\begin{array}{c}\mathrm{B} / \mathrm{H} \\
{[-]}\end{array}$ \\
\hline 2 & 0,40 & 17 & 0,11 & 1,89 & 35 & 42 & 0,36 & 5 & 17,9 & 3,6 \\
\hline
\end{tabular}

Blanckaert (2002) melakukan penelitian pada belokan saluran sebagaimnana yang telah dilakukan sebelumnya oleh Mockmore (1943), Einstein \& Keras (1954), Rozovskii (1957), pengukuran kecepatan pada belokan saluran dilakukan dalam arah 3 dimensi dilakukan dengan menggunakan ADVP. Kontur topografi dasar dan kecepatan dalam arah transversal atau melintang saluran gerusan mulai terjadi pada belokan 300 dan gerusan paling dalam pada belokan 450 , sebagaiman terlihat pada gambar 4.3.

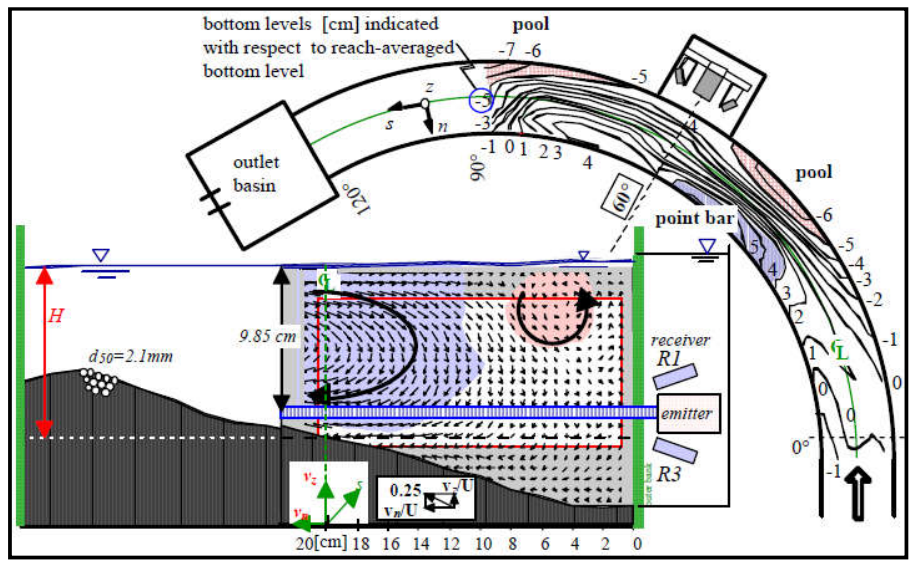

Gambar 6-3. Arah kecepatan melintang saluran dan topografi dasar padabelokan (Blanckaert, 2002) 


\subsection{Superelevasi}

Aliran spiral pada belokan saluran pertama kali diamati oleh James Thomson pada tahun 1876. Penyebab utama gejala aliran spiral adalah terjadinya gesekan pada dinding saluran sehingga menghasilkan kecepatan filamental lebih tinggi pada daerah di dekat pusat dibandingkan dengan di dekat dinding saluran, gaya sentrifugal mengelilingi lengkungan mengahasilkan suatu hal yang unik menyebabkan terjadinya peningkatan tinggi muka air pada bagian luar belokan saluran sedang bagian dalam lebih rendah. Dalam usaha untuk melukiskan pengaruh dan besarnya aliran spiral, pada belokan yang berbeda-beda, dan kondisi aliran yang bermacam-macam, menurut Ahmad Shukry (1950) dalam Chow (1989) digunakan istilah yang dinamakan kekuatan aliran spiral. Kekuatan aliran spiral didefinisikan sebagai rasio peresentase energi kinetik ratarata gerakan lateral, terhadap energi kinetik total aliran pada penampang yang ditinjau. Energi kinetik aliran tergantung pada kuadrat kecepatan aliran (Chow 1989), kekuatan penampang tersebut adalah;

$$
S_{x y}=\frac{u_{x y}^{2}}{u^{2}} \times 100
$$

Dengan: $\mathrm{u}_{\mathrm{xy}}$ adalah proyeksi vektor kecepatan rata-rata pada bidang xy dan $u$ adalah kecepatan rata-rata pada penampang, jadi untuk saluran lurus $S_{x y}=0$. 
Perubahan permukaan air dalam arah melintang saluran disebut superelevasi, dimana pada sisi luar belokan permukaan air naik sedang pada sisi dalam belokan permukaan air turun, secara praktis superlevasi diestimasi terhadap pengaruh kecepatan rata-rata aliran dan perbandingan antara lebar permukaan air dengan jari-jari belokan.

Permukaan air pada aliran belokan saluran dirumuskan dengan persamaan gerak aliran oleh Yen dkk. (1971), merumuskan persamaan matematik terhadap permukaan air dalam arah melintang dan memanjang pada belokan saluran dengan menggunakan koordinat selinder, dengan merumuskan kembali persamaan gerak untuk aliran turbulen, sehingga persamaan dapat dituliskan permukaan air dalam arah melintang dan memanjang sepanjang belokan saluran sebagai berikut;

$$
\begin{aligned}
\mathrm{S}_{\mathrm{r}}=\frac{\mathrm{u}_{\mathrm{m}}^{2}}{2 \mathrm{gr}}[2 & \frac{\mathrm{r}}{\mathrm{h}}\left(\frac{\overline{\mathrm{u}}}{\mathrm{u}_{\mathrm{m}}}\right)^{2} \sin \\
& \left.+\int_{\mathrm{z}_{\mathrm{o}} / \mathrm{h}}^{\mathrm{z}_{1} / \mathrm{h}} 2\left[\left(\frac{\overline{\mathrm{u}}}{\mathrm{u}_{\mathrm{m}}}\right)^{2} \frac{\overline{\mathrm{u}}}{\mathrm{u}_{\mathrm{m}}} \frac{\partial\left(\frac{\overline{\mathrm{v}}}{\mathrm{u}_{\mathrm{m}}}\right)}{\partial \theta}\right] \mathrm{d}\left(\frac{\mathrm{z}}{\mathrm{h}}\right)\right]
\end{aligned}
$$

Dengan :

$\mathrm{S}_{\mathrm{r}}=$ Kemiringan melintang saluran pada belokan

$\sin =\overline{\mathrm{v}} / \overline{\mathrm{u}}$

$\mathrm{u}=\sqrt{\overline{\tau_{\mathrm{o}}} / \rho}=$ Kecepatan geser

$\theta=$ sudut belokan saluran

$\mathrm{g}=$ gaya gravitasi

$\mathrm{h}=$ tinggi permukaan air

$\overline{\mathrm{u}}=$ Kecepatan rata-rata arah memanjang aliran

$\mathrm{r}=$ Jari-jari belokan saluran

$\overline{\mathrm{V}}=$ Kecepatan rata-rata arah melintang aliran 
$\rho=$ rapat massa zat air

$\mathrm{z}_{0}=$ kekasaran dasar saluran

$\mathrm{z}_{1}=\mathrm{z}=$ tinggi air

Apabila

$$
\begin{aligned}
& \mathrm{C}_{\mathrm{r} 1}=2 \frac{\mathrm{r}}{\mathrm{h}}\left(\frac{\overline{\mathrm{u}}}{\mathrm{u}_{\mathrm{m}}}\right)^{2} \sin , \\
& \mathrm{C}_{\mathrm{r} 1}=2 \int_{\mathrm{z}_{\mathrm{o}} / \mathrm{h}}^{\mathrm{z}_{1} / \mathrm{h}}\left(\frac{\overline{\mathrm{u}}}{\mathrm{u}_{\mathrm{m}}}\right)^{2} \mathrm{~d}\left(\frac{\mathrm{z}}{\mathrm{h}}\right), \text { dan } \\
& \mathrm{C}_{\mathrm{r} 1}=2 \int_{\mathrm{z}_{\mathrm{o}} / \mathrm{h}}^{\mathrm{z}_{1} / \mathrm{h}}\left(\frac{\overline{\mathrm{u}}}{\mathrm{u}_{\mathrm{m}}}\right) \frac{\partial\left(\frac{\overline{\mathrm{v}}}{\mathrm{U}_{\mathrm{m}}}\right)}{\partial \theta} \mathrm{d}\left(\frac{\mathrm{z}}{\mathrm{h}}\right) \\
& \text { maka } \mathrm{C}_{\mathrm{r}}=\mathrm{C}_{\mathrm{r} 1}+\mathrm{C}_{\mathrm{r} 2}+\mathrm{C}_{\mathrm{r} 3}
\end{aligned}
$$

Secara sederhana superelevasi dapat dinyatakan

$$
\mathrm{S}_{\mathrm{r}}=\mathrm{C}_{\mathrm{r}} \frac{\mathrm{u}_{\mathrm{m}}^{2}}{2 \mathrm{gr}}
$$

Dengan: $\mathrm{S}_{\mathrm{r}}=$ Kemiringan permukaan air

$\mathrm{C}_{\mathrm{r}}=$ Kemiringan permukaanterhadap as saluran

$\mathrm{u}_{\mathrm{m}}=$ Kecepatan rata-rata segmen

$\mathrm{g}=$ gaya gravitasi

$\mathrm{r}=$ jari-jari belokan saluran

Dengan integrasi numerik nilai $\mathrm{C}_{\mathrm{r} 1}, \mathrm{C}_{\mathrm{r} 2}$, dan $\mathrm{C}_{\mathrm{r} 3}$ dapat dihitung, sehingga profil permukaan air arah melintang pada setiap potongan,

$$
\mathrm{H}_{\mathrm{rc}}=\int_{\mathrm{rc}}^{\mathrm{r}} \mathrm{S}_{\mathrm{r}} \mathrm{dr}=\frac{\mathrm{u}_{\mathrm{m}}^{2}}{2 \mathrm{~g}} \int_{\mathrm{rc}}^{\mathrm{r}} \frac{\mathrm{C}_{\mathrm{r}}}{\mathrm{r}} \mathrm{dr}
$$

Dengan : $\quad \mathrm{H}_{\mathrm{rc}}=$ Perbedaan permukaan air arah melintang $(\mathrm{m})$

$\mathrm{u}_{\mathrm{m}}=$ Kecepatan rata-rata pada penampang $(\mathrm{m} / \mathrm{dtk})$

$\mathrm{g}=$ Gaya gravitasi

$\mathrm{r}=$ jari-jari saluran, $\mathrm{r}_{\mathrm{c}}=$ jari-jari pusat aliran

$\mathrm{C}_{\mathrm{r}}=$ kemiringan permukaan terhadap as saluran

Dengan menggunakan data dari dua model belokan saluran yang telah dilaksanakan penelitiannya di Iowa Institute Hydraulic Research, dan model tersebut dianggap sebagai 
mewakili sungai Mississippi dan Missouri, dimana terdapat dua belokan $90^{\circ}$, dengan dimensi hidrolis sebagai berikut:

Tabel 6-3. Ukuran dan hidrolis model (Yen dkk., 1971)

\begin{tabular}{|c|c|c|c|c|c|}
\hline $\begin{array}{c}\text { Bentuk } \\
\text { Penampang }\end{array}$ & $\mathrm{r}_{\mathrm{c}}$ & $\mathrm{B}$ & $\mathrm{R}_{\mathrm{e}}$ & $\mathrm{F}_{\mathrm{r}}$ & $\mathrm{r}_{\mathrm{c}} / \mathrm{B}$ \\
\hline Saluran segi empat & $28 \mathrm{ft}$ & $14 \mathrm{ft}$ & $0,7 \times 10^{5}$ s.d. $1,6 \times 10^{5}$ & 0,3 s.d. 0,7 & 2 \\
\hline Saluran trapesium & $28 \mathrm{ft}$ & $6 \mathrm{ft}$ & $2,5 \times 10^{5}$ s.d. $5,5 \times 10^{5}$ & 0,37 s.d. 0,82 & 4,67 \\
\hline
\end{tabular}

Superlevasi pada potongan melintang saluran dengan mengintegrasikann persamaan di atas

$$
\frac{\mathrm{H}_{\mathrm{s}}}{\frac{\mathrm{u}_{\mathrm{m}}^{2}}{2 \mathrm{~g}}}=\int_{\mathrm{r}_{\mathrm{i}}}^{\mathrm{r}_{\mathrm{o}}} \frac{\mathrm{C}_{\mathrm{r}}}{\mathrm{r}} \mathrm{dr}
$$

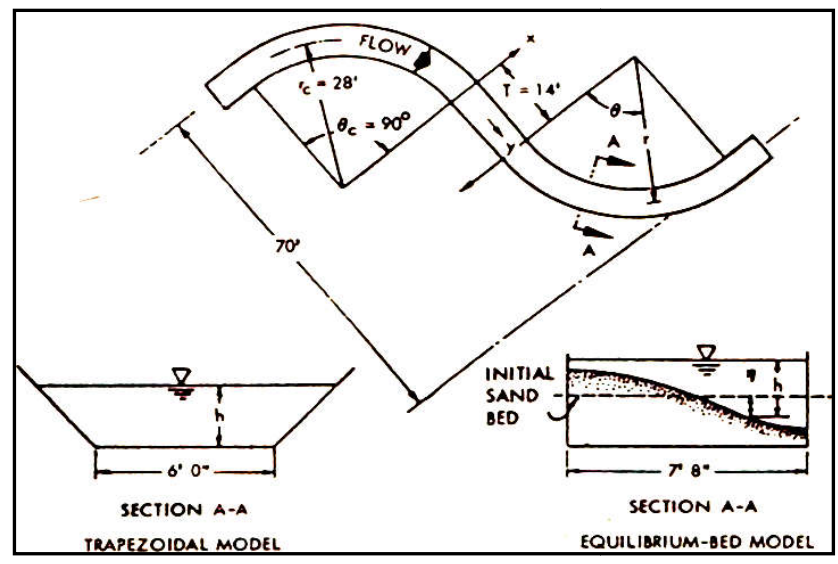

Gambar 6-4. Sketsa belokan saluran penelitian (Yen dkk.,1971) 


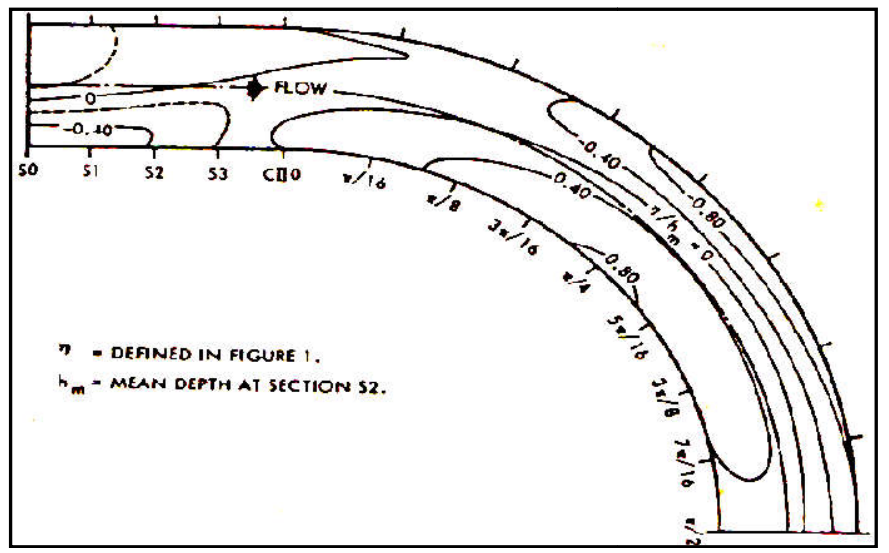

Gambar 6-5. Topografi dasar saluran untuk model penampang trapesium (Yen dkk., 1971)

Dengan: $\mathrm{H}_{\mathrm{s}}=$ Tinggi Superelevasi, $\mathrm{r}_{\mathrm{o}}=$ Jari-jari bagian dalam belokan, dan $r_{0}=$ Jari-jari bagian luar belokan, sehingga koefisien superlevasi dapat didefinisikan

$$
C_{s}=\frac{H_{s}}{\frac{U_{m}^{2}}{2 g}} \frac{r_{c}}{B_{s}}=\int_{r_{i} / r_{c}}^{r_{0} / r_{c}} \frac{C_{r}}{r} d\left(\frac{r}{r_{c}}\right)
$$

Dengan: $B_{s}=r_{o}-r_{i}$ lebar permukaan air melintang koefisien superelevasi berdasar atas pengukuran pada model dan perhitungan dengan analisa numerik oleh Yen dkk. (1971), dengan data mulai dari sudut belok $0^{0}$ sampai dengan $\Pi / 2$ sebagaimana pada gambar 13 menunjukkan bahwa koefisien superelevasi pada equilibrium bed modeljauh lebih besar dibandingkan dengan trapezoidal model. 


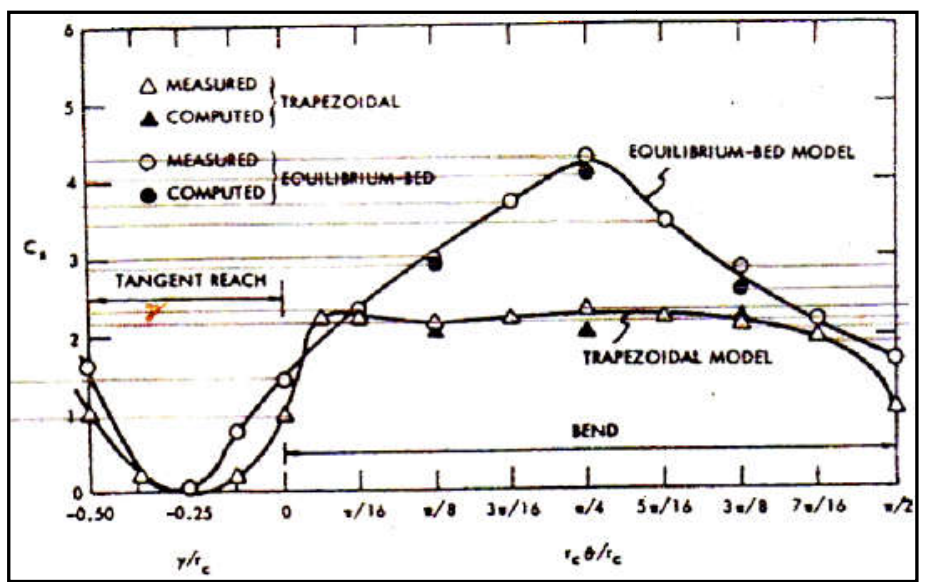

Gambar 6-6. Koefisien superelevasi (Yen dkk. 1971)

Mencermati besaran koefisien superlevasi $\left(\mathrm{C}_{\mathrm{s}}\right)$ pada gambar 4.6, untuk saluran equilibrium bed model nilai $\mathrm{C}_{\mathrm{s}}$ terbesar pada belokan $45^{0}$ nilai $\mathrm{C}_{\mathrm{s}}=4,2$ yang terkecil pada belokan $90^{\circ}$ dengan nilai $\mathrm{C}_{\mathrm{s}}=1,7$ dan di $0^{0}=1,5$, sedang saluran trapezoidal model menunjukkan nilai kurang lebih $\mathrm{C}_{\mathrm{s}}=$ 2,2 sedang terkecil di belokan $0^{0}$ dan $90^{\circ} \mathrm{C}_{\mathrm{s}}=1,0$. Ahmed Shukry $\left(195^{\circ}\right)$ dalam Chow (1985), dinyatakan bahwa nilai koefisien superelevasi rata-rata untuk dasar tanpa sedimen kurang lebih $\mathrm{C}_{\mathrm{s}}=2,0$, sedang untuk saluran dengan dasar bergerak atau dengan dasar sedimen $\mathrm{C}_{\mathrm{s}}=2,2$. Penelitian yang dilakukan di Fakultas Teknik Universitas Tadulako (Ishak, M. Galib, 2015) hasilnya menunjukkan bahwa baik dengan dasar sedimen maupun dengan sedimen, pilar dan tanpa pilar menunjukkan bahwa nilai $\mathrm{C}_{\mathrm{s}}<4$, dan nilai maksimum terjadi pada belokan 300, direkomendasikan dalam aplikasi $\mathrm{C}_{\mathrm{s}}=4$, artinya untuk mengetahui tinggi kenaikan muka air adalah 
dengan memasukkan kecepatan rata-rata, lebar sungai, jari-jari belokan pada rumus $\mathrm{C}_{\mathrm{s}}=\mathrm{H}_{\mathrm{s}} /\left(\mathrm{U}^{2} / 2 \mathrm{~g}\right){ }^{*} \mathrm{r}_{\mathrm{c}} / \mathrm{B}_{\mathrm{s}}$.

Analisis permukaan air, topografi dan tegangan geser dasar saluran sebagaimana penelitian yang dilakukan oleh Kironoto (1982) yang dilaksanakan pada saluran alamiah di belokan sungai Baldwin Creek dekat Lander, Wyoming, dimulai pada sungai sepanjang $100 \mathrm{~m}$, kemudian masuk kesaluran yang berbelok dengan sudut belokan sungai sebesar 180 , Jari-jari belokan $\mathrm{R}=10,7 \mathrm{~m}$, debit $1,96 \mathrm{~m}^{3} / \mathrm{dt}$. Hasil penelitian menunjukkan bahwa zona terdalam saluran belum tentu menghasilkan tegangan geser terbesar, karena berdasar atas pengukuran dimana terdapat air dangkal dengan sedimen pasir tergerus.

6.3 Distribusi Kecepatan pada Belokan Sungai

Mozzafari (2011), pada gambar 14 dan 15 memperlihatkan perbandingan antara hasil perhitungan dengan rumus-rumus oleh peneliti sebelumnya yaitu Rozovskii (1961), Kikkawa dkk. (1976), Johannesson and Parker (1989) dan Bridge (1992) hasil pengukuran dengan menggunakan alat ADVP. Pada gambar di bawah menunjukkan bahwa dengan menggunakan rumus logarithmic velocity profile kecepatan maksimum pada permukaan sedang dengan menggunakan ADVP hasilnya kecepatan merata setelah $\mathrm{z} / \mathrm{h}=2$ baik pada sisi luar maupun pada sisi dalam belokan, demikian juga terjadinya perbedaan hasil dengan menggunakan rumus-rumus yang 
dilakukan oleh peneliti sebelumnya, gambar 4.7 menunjukkan bahwa profil kecepatan pada belokan tidak membentuk lengkung logaritmik.

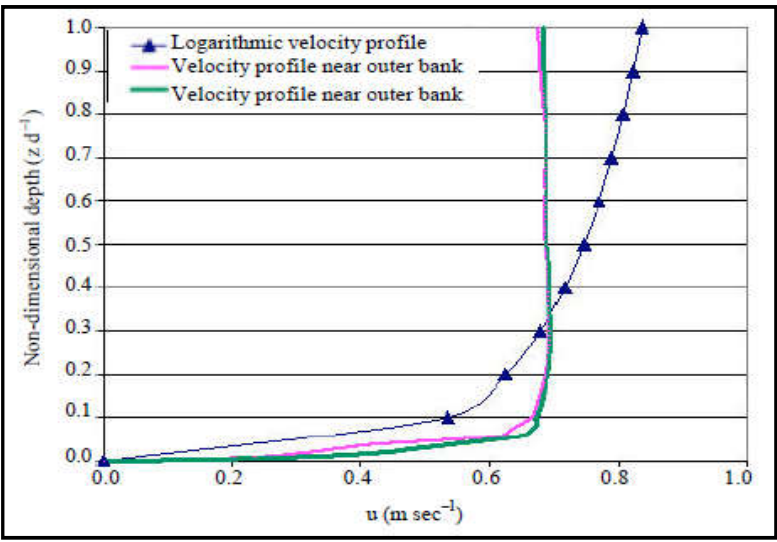

Gambar 6-7.Pengukuran profil kecepatan pada potongan melintang $180^{\circ}$ (Mozaffari, 2011)

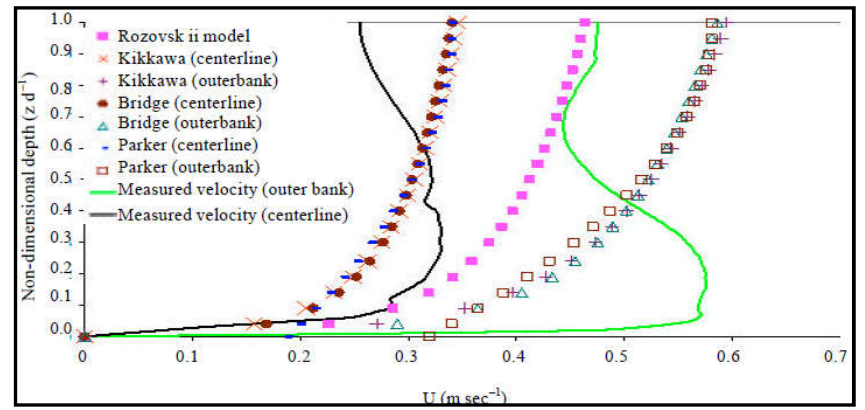

Gambar 6-8. Profil kecepatan beberapa model penelitian untuk debit 63 lt/dt(Mozaffari, 2011)

Mekanika Fluida Delft University of Technology(DUT), saluran ini sebagai model dari sungai alamiah, tinggi air $\mathrm{h}=$ $0,05 \mathrm{~m}$, lebar $\mathrm{B}=0,5 \mathrm{~m}$ dan jari-jari $\mathrm{r}_{\mathrm{c}}=4,10 \mathrm{~m}$, debit $5,2 \mathrm{lt} / \mathrm{dt}$ $=0,0052 \mathrm{~m}^{3} / \mathrm{dt}$, kecepatan aliran $=0,2 \mathrm{~m} / \mathrm{dt}$, belokan saluran 180 . Model ini merupakan aliran yang dangkal $(\mathrm{B} / \mathrm{h}=10)$ dan 
belokan sungai $\left(\mathrm{R}_{\mathrm{d}} / \mathrm{h}=80\right)$. Setelah dilakukan perhitungan terhadap dimensi aliran sehingga diperoleh hasil bahwa bilangan Reynolds sebesar $\mathrm{R}_{\mathrm{e}}=10.000$, dan bilangan Froude sebesar $F_{r}=0,02$. Penelitian ini difokuskan pada distribusi kecepatan dalam arah $3 \mathrm{D}$

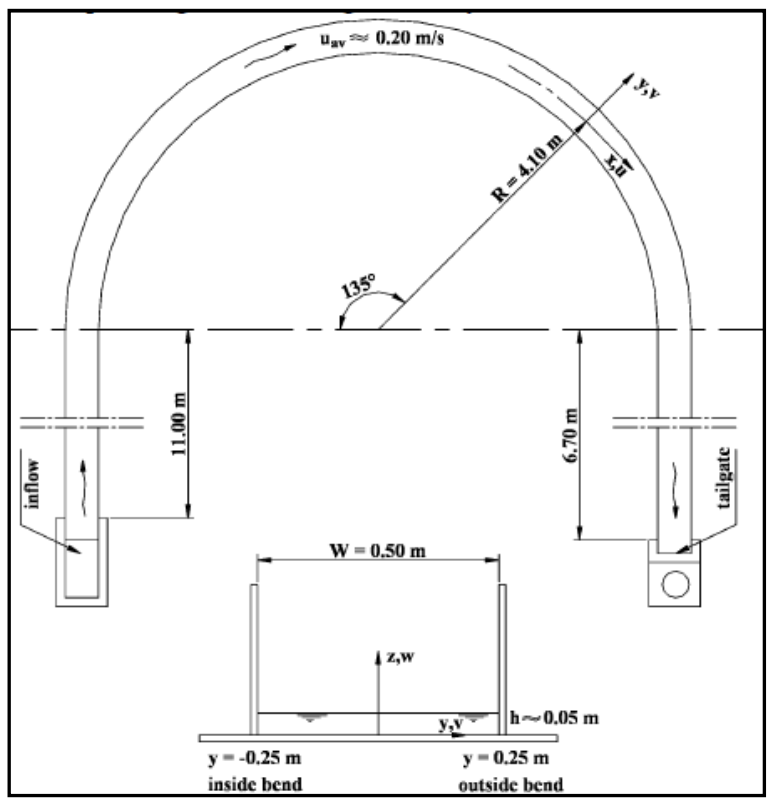

Gambar 6-9. Model belokan saluran di Delft University of Technology (Booij, 2003)

Hasil pengukuran dengan menggunakan alat Laser Doppler Velocity (LDP) dalam arah 3 dimensi hasilnya menunjukkan bahwa adanya aliran sekunder arah melintang belokan saluran sebagaimana pada Gambar 6-10. 


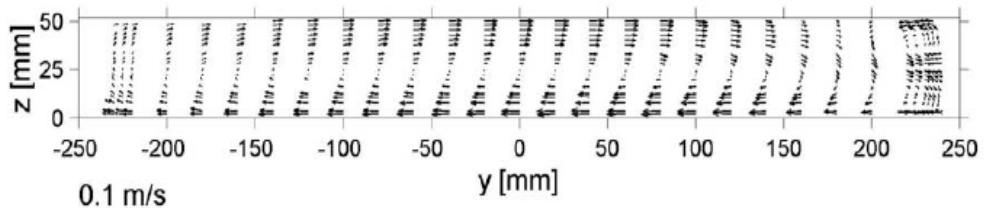

Gambar 6-10. Hasil pengukuran kecepatan sekunder atau biasa disebut kecepatan arah melintang saluran (Booij, 2003)
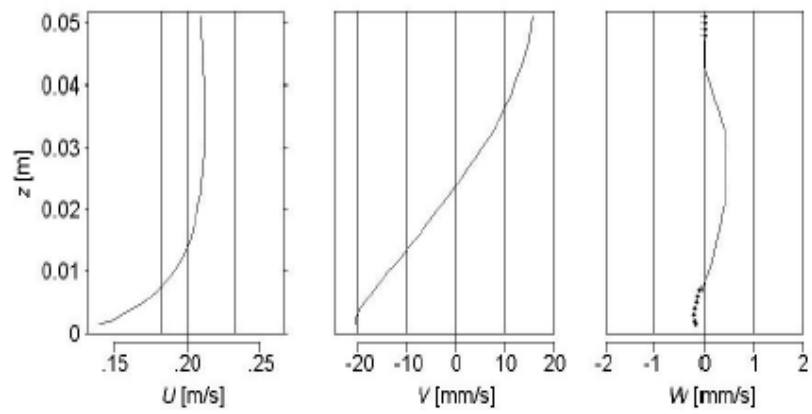

Gambar 6-11. Profil vertikal terhadap pengukuran komponen kecepatan (Booij, 2003)

Gambar 6-11 menunjukkan bahwa kecepatan aliran dalam memanjang saluran (u) menunjukkan bahwa distribusi kecepatan membentuk logaritmik, dan untuk arah melintang saluran (v) semakin mendekat kepermukaan kecepatannya semakin besar, sedang arah vertikal (w), dekat dasar terjadi aliran negatif, maksimum kecepatan pada bagian tengah penampang dan besarnya relatif kecil dibandingkan dengan kecepatan arah longitudinal atau kecepatan memanjang saluran.

Penelitian yang dilakukan oleh Duan (2004)dengan simulasi model terhadap hasil penelitian yang telah dilakukan oleh dua peneliti de Vriend (1979) $r_{c} / B=3,5$ dan Rozovskii 
(1961) $r_{c} / B=1$ dengan belokan $180^{\circ}$, membandingkan dengan simulasi model matematis.

Tabel 4. Data geometrik saluran dan parameter aliran yang disimulasi

\begin{tabular}{|c|c|c|c|c|c|}
\hline Peneliti & $\begin{array}{c}\text { Debit Q } \\
\left(\mathbf{m}^{\mathbf{3}} / \mathbf{d t}\right)\end{array}$ & $\begin{array}{c}\text { Lebar } \\
\mathbf{B}(\mathbf{m})\end{array}$ & $\begin{array}{c}\text { Kedalaman } \\
\mathbf{h}(\mathbf{m})\end{array}$ & $\begin{array}{c}\text { Kecepatan } \\
(\mathbf{m} / \mathbf{d t})\end{array}$ & $\mathbf{r}_{\mathbf{c}} / \mathbf{B}$ \\
\hline De Vriend (1979) & 0,0671 & 1,7 & 0,1953 & 0,202 & 3,5 \\
\hline Rozovskii (1961) & 0,0123 & 1,7 & 0,0530 & 0,265 & 1,0 \\
\hline
\end{tabular}

Sumber : Duan (2004)

Aliran melalui belokan saluran yang tidak tajam $r_{c} / B=$ 3,5 (de Vriend 1979), aliran dengan penampang tetap lebar 1,7 $\mathrm{m}$ dasar yang horizontal dengan dinding tegak, panjang saluran sebelum belokan 4,25 m, setelah belokan 6,0 m, dengan sudut belokan 180 . Perbandingan antara jari-jari belokan dengan lebar adalah 3,5. Debit pengujian sebesar $0,0671 \mathrm{~m}^{3} / \mathrm{dt}$, kecepatan rata sebesar $0,202 \mathrm{~m} / \mathrm{dt}$, kedalaman rata-rata 0,1953 m. Pengukuran aliran dilakukan dengan 49 potongan melintang, setiap potongan melintang diukur dengan 23 titik.

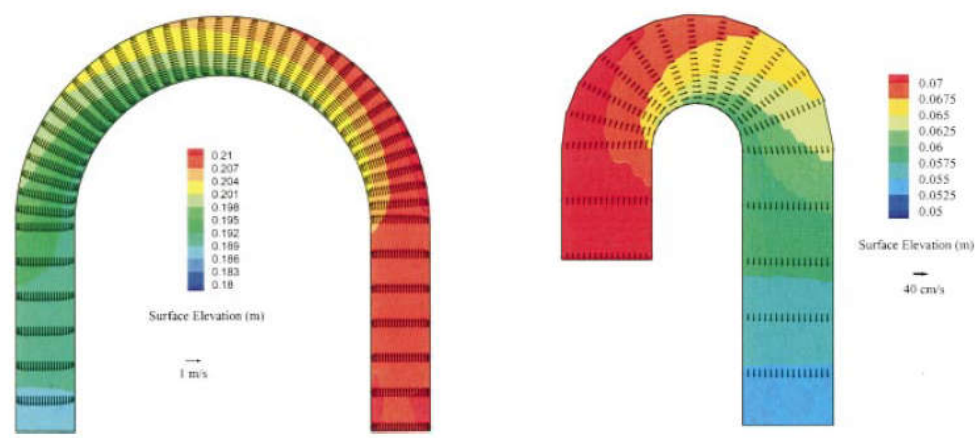

Gambar 6-12. Model fisik penelitian (de Vriend,1979 dan Rozovskii, 1961 dalam Duan, 2004) 
Dengan membuat persamaan pengatur (model matematis) seperti persamaan momentum aliran sebagai berikut: a. Persamaan logarithmic law

$$
\frac{\mathrm{u}_{\mathrm{l}}}{\mathrm{u}}=\frac{1}{\mathrm{~K}} \ln \left\{\frac{\mathrm{z}}{\mathrm{z}_{\mathrm{o}}}\right\}
$$

b. Hasilnya menunjukkan bahwa penurunan kecepatan pada belokan sebelah dalam, sedang pada sebelah luar belokan terjadi kenaikan kecepatan. Akselerasi terhadap perubahan aliran pada belokan sebelah dalam disebabkan adanya pergeseran dalam arah melintang aliran terhadap perubahan momentum aliran sekunder, belokan aliran yang mempunyai jari-jari yang besar dibandingkan dengan lebar aliran sangat sedikit pengaruhnya terhadap aliran sekunder dalam arah potongan melintang saluran.

\subsection{Belokan Saluran dengan Hambatan}

Mempelajari kedalaman gerusan di sekitar pilar jembatan di belokan sungai sebagaimana penelitian yang telah dilakukan oleh Masjedi dkk. (2007) dengan membuat model flume di laboratorium dengan belokan $180^{\circ}, r_{c} / B=4,7 \quad\left(r_{c}=\right.$ jari-jari belokan, $\mathrm{B}=$ Lebar flume), diameter pilar $6 \mathrm{~cm}$, dengan memindah-mindahkan pilar dari posisi $0^{0}, 30^{\circ}, 60^{\circ}, 90^{\circ}, 120^{\circ}$, $150^{\circ}$, dan $180^{\circ}$, kedalaman air konstan $12 \mathrm{~cm}$, pasir alam yang seragam $D_{50}=2 \mathrm{~mm}$ dengan faktor keseragaman 1,7 yang digunakan sebagai dasar saluran, debit aliran sebesar 18, 20 
ltr/dt. Hasil penelitian menunjukkan bahwa aliran alami di sungai khususnya di tikungan dimana terdapat pilar jembatan sangat mempengaruhi tingkat kedalaman gerusan yang mana turbulensi semakin besar dan gaya sentrifugal akibat belokan juga berpengaruh.

Menurut Masjedi dkk. (2007) bahwa tumbukan air pada pilar yang berbentuk selinder menimbulkan pusaran air, peneliti sebelumnya juga telah membuat model pada saluran lurus seperti yang dilakukan Chiew (1987), Breusers (1991), Melville (2002) dan Dargahi (1987). Syarat yang direkomendasikan terhadap suatu model dengan hambatan oleh Chiew (1987)dalam Masjedi dkk.(2007) bahwa maksimum ukuran pilar $10 \%$ terhadap lebar saluran untuk menghindari pengaruh dinding saluran, dan ukuran minimal diameter pilar $1: 65$, pada penelitian ini digunakan PVC dengan diameter $6 \mathrm{~cm}$, untuk ukuran diameter partikel model sedimen minimal $1: 50$, sedang pada penelitian ini menggunakan 1:25-30, pasir yang digunakan harus lebih besar dari $0,7 \mathrm{~mm}$, untuk penelitian ini digunakan pasir alami dengan diameter rata-rata $2 \mathrm{~mm}$ dengan standar deviasi 1,3 dengan ketebalan $30 \mathrm{~cm}$ sepanjang saluran. 


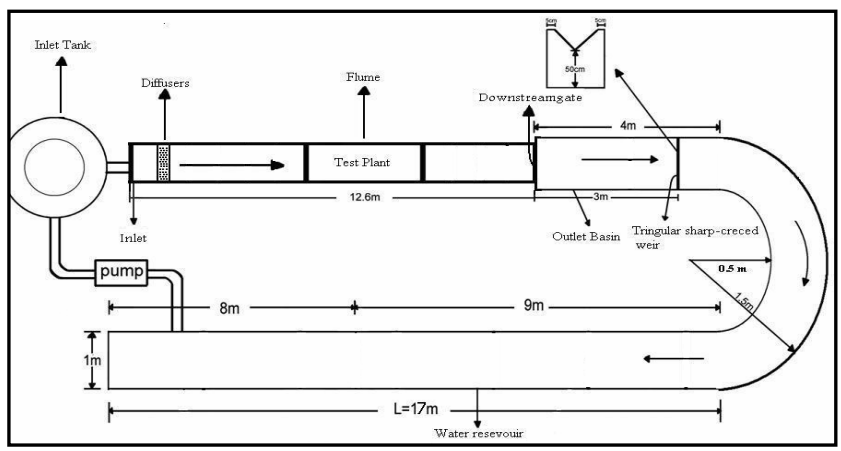

Gambar 6-13. Model saluran yang digunakan dalam penelitian (Masjedi dkk., 2007)

Untuk mencegah pengaruh kekasaran saluran kedalaman air minimal 20 mm Ippen (1962) dalam Masjedi (2009), pada penelitian ini dipertahankan kedalaman air konstan $12 \mathrm{~cm}$, untuk menghindari transportasi sedimen disepanjang saluran diisyaratkan kecepatan rata-rata aliran tidak melebihi kecepatan kritis $\left(\mathrm{u}<\mathrm{u}_{\mathrm{cr}}\right)$, dimana dengan kecepatan relatif mulai dari 0,75 , 0,86, 0,93, dan 1, dari hasil penelitian menunjukkan bahwa untuk debit 32 ltr/dt dengan posisi pilar 60 derajat padagambar 21. setelah 2 jam kondisi perpindahan sedimen hampir tidak terjadi lagi, pompa dimatikan dan dilanjutkan dengan pengukuran topografi sedimen dengan tingkat ketelitian 0,01 $\mathrm{mm}$. 


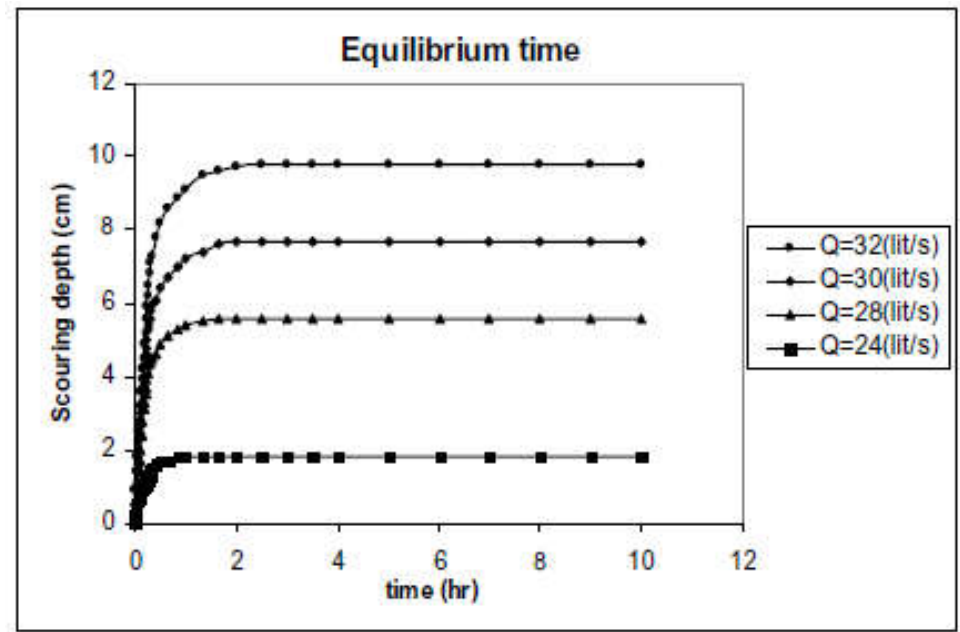

Gambar 6-14. Grafik stabilitas gerusan pada posisi $60^{\circ}$ (Masjedi dkk., 2007)

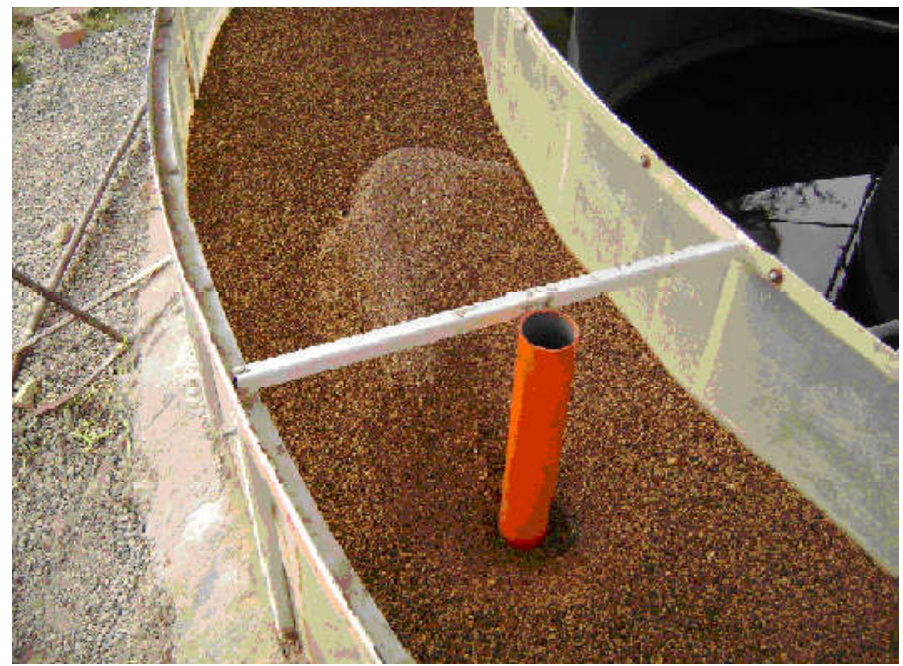

Gambar 6-15. Gerusan dengan pilar percobaan dengan debit 24, 28,30 , dan $32 \mathrm{ltr} / \mathrm{dt}$ 


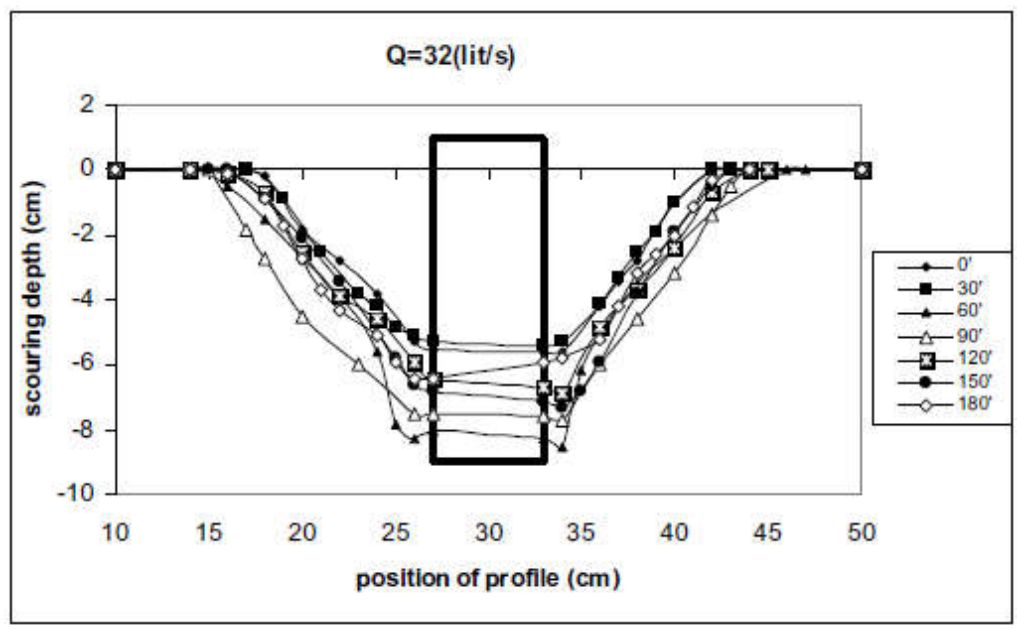

Gambar 6-16. Profil maksimum dalam arah melintang saluran dengan variasi kedalaman pada debit $32 \mathrm{ltr} / \mathrm{dt}$ (Masjedi dkk., 2007)

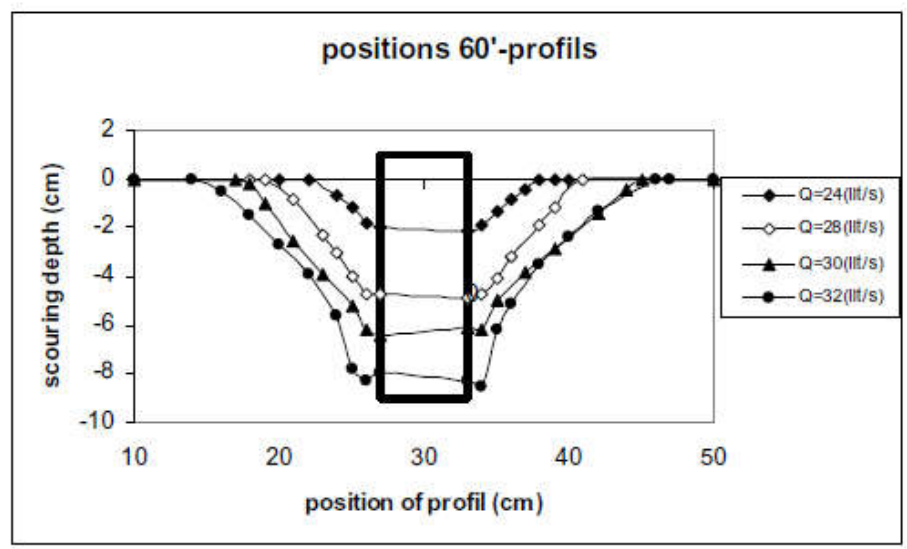

Gambar 6-17. Profil maksimum gerusan dengan dengan debit yang berbeda pada posisi 60 derajat (Masjedi dkk., 2007).

Mencermati Gambar 6-17 menunjukkan bahwa gerusan terdalam terjadi pada posisi pilar $60^{\circ}$, kedua terdalam pada posisi pilar $90^{\circ}$, dan gerusan terdangkal pada posisi pilar $30^{\circ}$ 
sedang pada gambar 24 menunjukkan semakin besar debit semakin besar gerusan.

\section{Soal Latihan 4}

1. Uraikan proses gerusan pada belokan sungai dan bagaimana cara mencegah gerusan tersebut agar tidak terjadi kerusakan

2. Uraikan gaya-gaya yang bekerja pada belokan sungai dan gaya apa saja yang sangat dominan?

3. Pada pengujian lab terlihat gaya atau kecepatan pada belokan bagain dalam lebih kecil dibandingkan pada belokan luar, uraikan penyebabnya?.

4. Berikan contoh-contoh perhitungan gaya-gaya pada belokan sungai dan aplikasi pada sungai dalam bentuk apa? 


\section{MODUL 7. PROSES FLUVIAL}

1. Sasaran Pembelajaran

- Mahasiswa dapat mengetahui prose fluvial

- Mahasiswa dapat mengetahui pergerakan sedimen

2. Kemampuan yang mahasiswa yang menjadi prasyarat Hidrolika, Hidrologi dan pengembangan sumber daya air.

3. Keterkaitan bahan pembelajaran dengan pokok bahasan lainnya sangat berkaitan dan merupakan satu kesatuan yang saling menunjang

4. Manfaat atau pentingnya bahan pembelajaran ini yaitu mahasiswa mampu memahami analisa angkutan sedimen dasar, sedimen melayang dan awal mula gerak sedimen.

5. Petunjuk belajar mahasiswa, penjelasan tentang hal hal yang perlu dilakukan mahasiswa dalam mempelajari materi ini yaitu dengan menampilkan beberapa contoh dan gambar serta memberi tugas mencari paper di internet sehingga akan memperkaya wawasan mereka.

\subsection{Sedimen di Sungai}

Adanya aliran pada sungai dengan keepatan tertentu akan mampu menyebabkan sedimen bergerak atau terangkut. Angkutan sedimen di sungai adalah proses alami.Sebagai media yang mengalirkan air, maka sungai untuk mengangkutsedimen berdasarkan kecepatan aliran hal berupa angkutan sedimen dasar (bed load) dan angkutansedimen layang (suspended load).

Angkutan sedimen yang dialirkan melalui saluran terbuka atau sungaidapat menyebabkan penumpukan sedimen terutama 
dibagian hilir sungaiyang dapat menyebabkanpendangkalan pada sungai dan hal ini mempengaruhi banyak aspek seperti kualitasair, pasokan air, pengendali banjir, umur rencana waduk,dan lain-lain.

\subsection{Pergerakan Sedimen}

Sumber potensial yang dapat mengakibatkan sedimen menjadi penyebab timbulnya kekeruhan maksimum di dalam perairan, diantaranya berasal dari: sungai, laut, erosi garis pantai estuari dan pasut, erosi dasar perairan, produksi biologi dan atmosfir. Pentingnya sumber-sumber ini sifatnya relatif, karena akan bervariasi antara perairan yang satu dengan yang lainnya, dan akan sangat tergantung pada siklus musiman (Dyer, 1986).

\subsubsection{Awal Sedimen Dasar Bergerak}

Gerak butiran sedimen disebabkan adanya gesekan aliran air pada permukaan butiran. Shield meneliti tegangan geser pada awal gerak butiran sebagai fungsi antara tegangan geser tak berdimensi $\tau_{\mathrm{c}^{*}}$ dan angka reynold butiran $\mathrm{R}_{\mathrm{e}^{*}}$. Dengan demikian koefisien seret $\mathrm{CD}$ dan koefisien geser antar butiran coulomb $\mu \mathrm{c}$ sudah termasuk dalam perhitungan grafik tersebut. Selanjutnya digambarkan hubungan empiris tersebut oleh Rouse (ASCE 1975). 


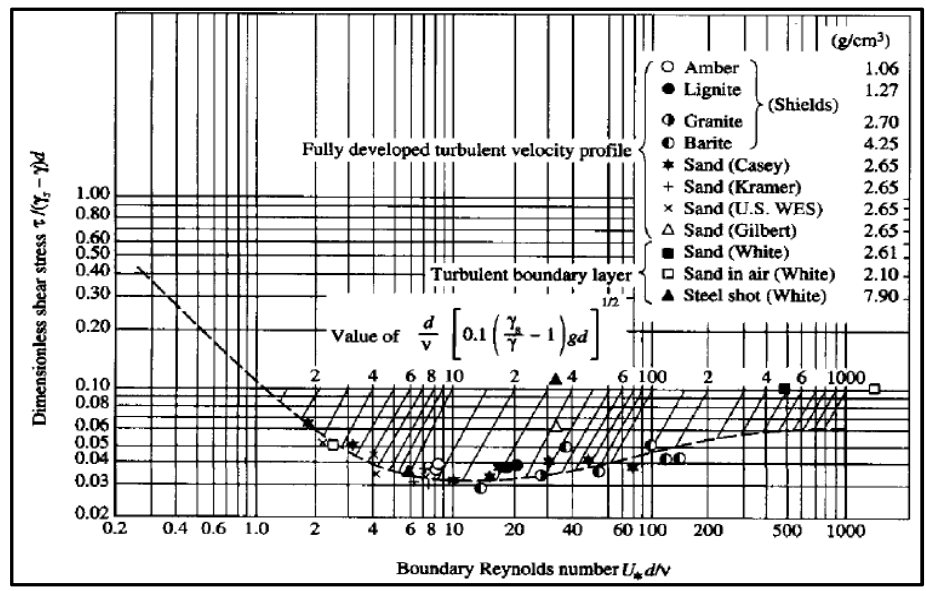

Gambar 7-1. Grafik Shield Modifikasi (Rouse 1939, ASCE 1975)

Pada dasarnya aplikasi untuk tegangan kritik shield terlalu besar, hal ini dapatterjadi karena asumsi yang digunakan Shield (1900) sebagai awal gerakan pertama tidak memperhitungkan formasi dasar, kedua tidak melihat entrainmentsporadis sebagai awal gerak dan terakhir pengujian menggunakan butiranpartikel uniform yang lebih sulit bergerak.

Dalam hubungan dengan pemodelan numerik transporsedimen tersuspensi, adalah penting untuk mengidentifikasi kondisiperpindahan massa partikel sedimen pada lapisan dekat dasar darimuatan tersuspensi. Salah satu permasalahan meliputi penentuan kondisi aliran dimana awal dari sedimen tersuspensi terjadi (Cheng dan Chiew, 1999). Walaupun demikian pentingnya, hanya beberapapenelitian yang berkaitan dapat diperoleh dalam literatur, misalnya Bagnold (1966), Xie (1981), van Rijn, 1984, Summer (1986) dan Celik 
dan Rodi (1991). Penelitian-penelitian tersebut selalu memberikan hasil yang berbeda dalam menentukan kondisi awal dari suspensi.

Sebelum menganalisis parameter-parameter utama yangmempengaruhi sedimen tersuspensi, menjadi suatu hal pentinguntuk menentukan kondisi aliran dimana awal suspensi akan terjadi. Bagnold (1966) menyatakan partikel hanya berada dalam keadaan tersuspensi apabila turbulensi eddis $\left(v_{\text {up }}\right)$ memiliki kecepatan vertikal dominan dan melebihi kecepatan jatuh partikel sedimen $W_{s}$ Dia membuat hubungan kecepatan ke atas (upward velocity) dari turbulensi eddis terhadap kecepatan geser dalam bentuk :

$$
v_{\text {up }}=1,25 \mathrm{u} *
$$

selanjutnya untuk kondisi kritis sedimen suspensi ditulis sebagai berikut :

$$
\frac{W_{s}}{U}=1,25
$$

Persamaan 5.1 berarti bahwa partikel akan berada dalam kondisi suspensi apabila Ws/u* $<1,25$. Xie (1981) menurunkan kondisi untuk awal sedimen tersuspensi dari persamaan Rouse (1939) untuk distribusi sedimen tersuspensi. Profil dari konsentrasi relatif sedimen tersuspensi tergantung pada parameter Rouse $\mathrm{z}=\mathrm{Ws} / \mathrm{K} . \mathrm{u}^{*}$, dimana $\mathrm{K}=$ adalah konstanta von Karman ( $=0,4$ untuk air bersih (clear water). Dengan meningkatnya nilai parameter Rouse, profil menjadi meningkat tidak seragam dan jumlah dari sedimen ditransporkan dalam 
bentuk muatan tersuspensi menurun. Pada $z=5$, jumlah dari muatan tersuspensi menjadi sangat kecil, dan Xie mendefenisikan awal dari suspensiterjadi pada kondisi.

$$
\frac{\mathrm{W}_{\mathrm{s}}}{\mathrm{U}}=1,25
$$

Kondisi awal sedimen tersuspensi diidentifikasi oleh van Rijn (1984) bahwa pada saat pergerakan ke atas partikel sedimen telah melompat setinggi 100 kali diamater partikel. Hasilpenelitiannya ditampilkan dalam hubungan berikut:

$$
\begin{aligned}
& \frac{U_{s}}{W}=\frac{4}{d} \text { untuk } 1<d<10 \\
& \frac{U_{s}}{W}=0,4 \quad \text { untuk d }>10
\end{aligned}
$$

Dimana; $\mathrm{d}_{*}=\left(\Delta \mathrm{g} / \mathrm{v}_{2}\right)^{1 / 3}, \mathrm{~d}=$ partikel sedimen tanpa dimensi, $\Delta=\left(\rho_{\mathrm{s}}-\rho\right) / \rho ; \rho_{\mathrm{s}}=$ densitas partikel, $\rho=$ densitas fluida, $\mathrm{g}=$ percepatan gravitasi, $\mathrm{v}=$ viskositas kinemetik fluida, $\mathrm{d}=$ diameter partikel.

Sumer (1986) memformulasikan kondisi untuk awal sedimen tersuspensi dari dasar sebagai berikut:

$$
\begin{array}{rlrl}
\tau_{*} & =\frac{17}{R_{*}} & \text { untuk } & R_{*} \prec 70 \\
\tau_{*}=0,27 & \text { untuk } & R_{*} \succ 70
\end{array}
$$

Dimana $\tau_{*}=u_{*}^{2} /(\Delta g d)=$ parameter Shields, dan $\mathrm{R}^{*}=\mathrm{u}^{*} \mathrm{~d} / \mathrm{v}$ 
Celik dan Rodi (1991) menggunakan hubungan empiris berikut untuk menentukan tegangan geser kritis untuk suspensi dari dasar :

$$
\begin{array}{lll}
\tau_{*}=\frac{0,15}{R_{*}} & \text { untuk } & R_{*} \leq 0,6 \\
\tau_{*}=0,25 & \text { untuk } & R_{*} \succ 0,6
\end{array}
$$

\subsubsection{Enegi/Gaya yang Bekerja Pada Partikel Sedimen}

Berdasarkan pendekatan yang diusulkan olehShields (1936), sedimen bergerak dapat dianalisis berdasarkananalisis dimensidengan demikian sedimen akanmulai bergerak. Kecepatan ini dikatakan kecepatan aliran kritis.

Seperti yang diperlihatkan dalam Gambar 5.2. Untuk sungai dengankemiringannya yang relatif kecil memperlihatkan gayayang bekerja pada butiran sedimen, maka komponen gaya gravitasi dalam arah aliran dapat diabaikan. Partikel sedimen berada pada kondisi mulai bergerak apabila memenuhi kondisi : $\mathrm{F}_{\mathrm{L}}=\mathrm{Ws} ; \mathrm{F}_{\mathrm{D}}=\mathrm{F}_{\mathrm{R}}$ dan $\mathrm{Mo}=\mathrm{M}_{\mathrm{R}}$; dimana $: \mathrm{M}_{\mathrm{o}}=$ moment penggelinding yang disebabkan oleh $F_{D}$ dan $F_{R}, M_{R}=$ momen penahan yang disebabkan oleh $\mathrm{F}_{\mathrm{L}}$ dan $\mathrm{W}_{\mathrm{s}}$.

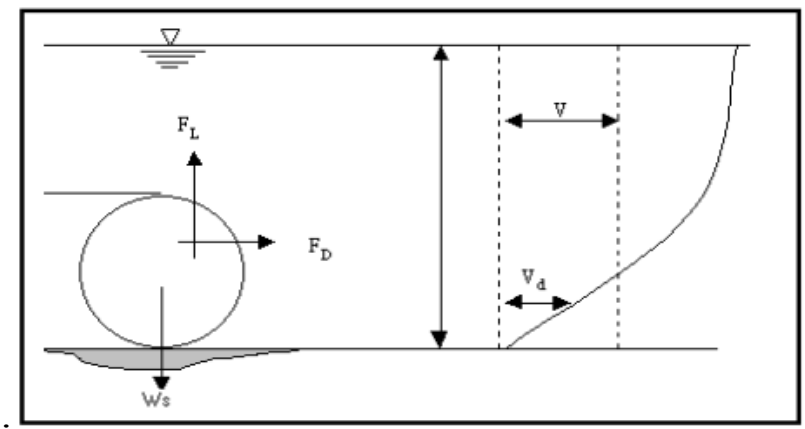

Gambar 7-2. Diagram gaya yang bekerja pada partikel sedimen. 
dimana $: d=$ diamater partikel sedimen,$D=$ kedalaman air, $F_{D}$ = gaya penarik (drag force $), \mathrm{F}_{\mathrm{L}}=$ gaya angkat, $\mathrm{W}_{\mathrm{s}}=$ berat di bawah permukaan air (submerged weight), dan $\mathrm{F}_{\mathrm{R}}=$ gaya penahan (resistance force). Sumber : Yang (1996).

Jika gaya eksternal yang bekerja pada permukaan sedimen cukup kuat, makamaterial dasar akan tererosi dari dasar dan akan tersuspensiatau sedimen yang berada pada lapisan bagian bawah akan naikkelapisan yang bagian atas.Klasifikasi kejadian tersebut dapatditinjau dari tegangan geser dasar. Jika tegangan geser dasar $\left(\tau_{\mathrm{b}}\right)$ lebih besar dari tegangan kritis erosi $\left(\tau_{\mathrm{ce}}\right)$,maka akan terjadi erosi, dan jika tegangan geser dasar lebih kecil dari tegangan kritis pengendapan $\left(\tau_{\mathrm{cd}}\right)$ maka akan terjadipengendapan. Sedangkan sedimen akan tetap berada dalam keadaan tersuspensi apabila tegangan geser dasar berada pada kedua nilai tegangan kritis tersebut. Secara ringkas proses umumtranspor sedimen dapat diperlihatkan dalam Gambar 7-3.

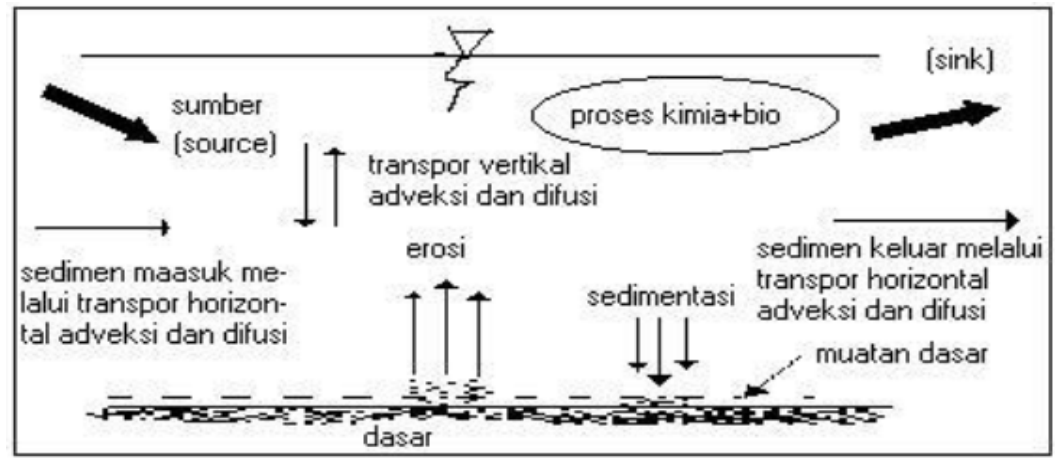

Gambar 7-3. Deskripsi umum proses transpor sedimen. 


\subsubsection{Karakteristik Sedimen}

Karakter sedimen dalam terhadap aliran air dapat dijelaskan dengan mengetahuipertama bagaimana gerakan jatuh sedimen (kecepatan pengendapan $=$ settling velocity) dengan adanya aliran air. Kedua bagaimana aliran dapat menggerakan partikel sedimen. Ketiga bagaimana pengaruh gerakan satu partikel sedimen terhadap partikel sedimen lainnya terkait dengan uniformitas dan faktor bentuk butirannya. Keempat bagaimana butiran sedimen terdistribusi pada arah vertikal. Dan terakhir adalah bagaimana gerakan partikel tersebut akan membentuk formasi dinamis untuk meningkatkan stabilitas bentuk dasar sehingga kekasaran total dasar sungai akan meningkat. Kekasaran total=kekasaran karena butiran (skin friction) ditambah kekasaran formasi sedimen (tekanan bentukdasar/formasi misal ripple, dune, bar).

Yang masih kurang mendapat perhatian adalah bagaimana kecepatan pergeseran formasi dasar dapat digunakan untuk menghitung angkutan sedimendimana sudah ada teori tentang ini tetapi saat ini belum ada lagi yang mengembangkannya terutama dari sisi pengukuran.Gerakan pertikel dalam air dipengaruhi oleh karakter dari butiran partikeltersebut, karakter dari fluida, dan karakter/jenis dari alirannya. Jika partikel sedimen dalam air bergerak, maka terjadi geseran (gaya seret) antara permukan partikel dengan fluida di sekelilingnya, yang arahnya berlawanan dengan gerakan. Besar gaya seret ini dipengaruhi oleh faktor bentuk (corey shape 
factor)dan tekstur dari permukan partikel, sedangkan karakter fluidanya adalah kekentalan fluida yang merupakan fungsi dari suhu.

(Corey shape factor)

$$
\mathrm{csf}=\mathrm{c} /(\mathrm{ab})^{1 / 2}
$$

Karakter aliran dalam hal ini ada dua, yaitu kondisi laminer dimana perambatangeseran arah vertikal antar partikel fluida relatif kecil sehingga geseran akan merupakan lapis-lapis dari partikel fluida, pada kondisi ini tekanan antara lapisanlapisan relatif kecil. Kondisi ini disebut laminer (geseran laminer).Sedangkan kemampuan transfer geseran antara partikel fluida disebut kekentalan fluida. Semakin kental (viskositas $\mu$ kecil) akan memungkinkan selisihkecepatan (du/dy) yang besar antara lapis-lapis fluida, sehingga rambatangeseran lapis-lapis pada arah vertikal y menjadi lebih sempit.

$$
\tau_{\mathrm{y}}=\mu \mathrm{du} / \mathrm{dy}
$$

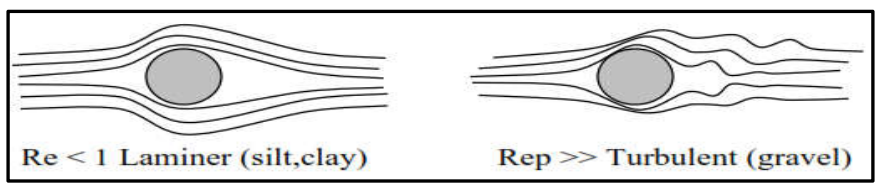

Gambar 7-4. Gambar aliran laminer dan turbulen

\subsubsection{Sedimentasi}

Secara skematis angkutan sedimen dapat digambarkan sebagai berikut: 


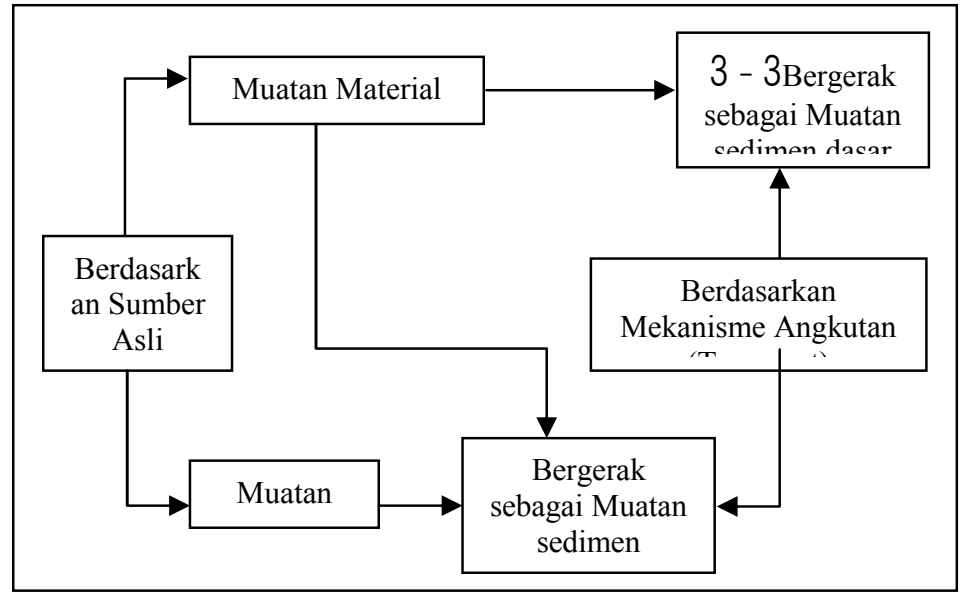

Gambar 7-5. Skema angkutan sedimen. (Sumber, Soewarno (2000; 646 )

Menurut, Mardjikoen (1988;24) bahwa angkutan sedimen secara umum terbagi menjadi sedimen dasar (bed load), sedimen layang (suspended load) dan sedimen loncat (saltation load).

Dasar sungai terdiri dari endapan material akibat angkutan sedimen yang terbawa oleh aliran sungai. Berdasarkan sumber asalnya muatan sedimen dibedakan : muatan material dasar dan muatan bilas. Sedangkan proses sedimentasi meliputi proses erosi, transportasi, pengendapan (deposition) dan pemadatan (compaction) dari sedimen tersebut. Keadaan bergeraknya sedimen tersebut sangat tergantung kepadaberat spesifik butiran, ukuran partikel, dan bentuk sedimen. 


\section{MODUL 8. HITUNGAN ANGKUTAN SEDIMEN}

1. Sasaran Pembelajaran

- Mahasiswa dapat mengetahui mekanisme angkutan sedimen dan gaya-gaya yang bekerja pada partikel sedimen

- Mahasiswa dapat mengetahui analisaangkutan sedimen dan penentuan lengkung debit-sedimen.

2. Kemampuan yang mahasiswa yang menjadi prasyarat Hidrolika, Hidrologi dan pengembangan sumber daya air.

3. Keterkaitan bahan pembelajaran dengan pokok bahasan lainnya sangat berkaitan dan merupakan satu kesatuan yang saling menunjang

4. Manfaat atau pentingnya bahan pembelajaran ini yaitu mahasiswa mampu memahami analisa angkutan sedimen dasar, sedimen melayang dan awal mula gerak sedimen.

5. Petunjuk belajar mahasiswa, penjelasan tentang hal hal yang perlu dilakukan mahasiswa dalam mempelajari materi ini yaitu dengan menampilkan beberapa contoh dan gambar serta memberi tugas mencari paper di internet sehingga akan memperkaya wawasan mereka.

\subsection{Transpor Sedimen}

Transport sedimen merupakan interaksi antara aliran air dan material dasarsaluran, sehingga merupakan proses yang kompleks. Laju transpor sedimen biasanya diekspresikan sebagai produk konsentrasi dan kecepatan fluida (Shibayama dan Winyu, 1993).Umumnya transpor sedimen dikelompokkan atas tiga kelompokyakni: bed load, suspended load dan wash 
load.Selama proses transpor, sedimen dapat mengalamipengendapan, hal ini disebabkan oleh pengaruh kecepatan jatuh $\left(\mathrm{W}_{\mathrm{s}}\right)$ sedimen.Sedimen yang ditransporkan di wilayah pantaibiasanya mengandung partikel-partikel kerikil atau pasir sampaipartikel berukuran yang biasa diklasifikasikan sebagai lumpur ataulempung.

Gaya luar yang bekerja pada unit massa cairan berdasarkan penyebabnya akan berbeda untuk arus sungai, arus akibat gelombang, serta arus dan gelombang yang berintegrasi secarabersama-sama. Gaya yang merupakan faktor utama pembangkitgerak transpor sedimen adalah arus pasang surut, arus litoral, medan gelombang dan debit sungai. Oleh karena itu dalammempelajari mekanisme transpor sedimen gaya-gaya penggeraktersebut perlu diperhatikan.

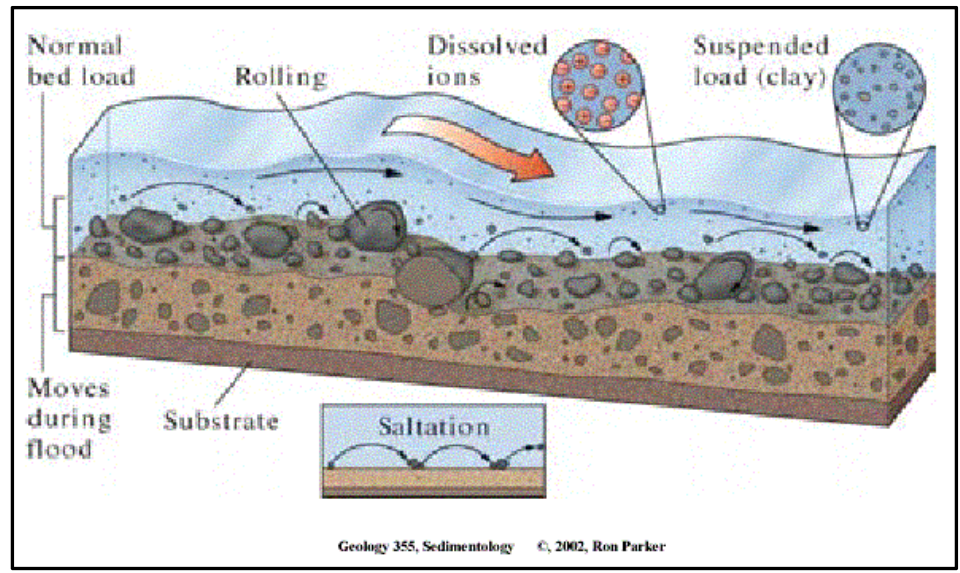

Gambar 8-1. Model angkutan sedimen (Ron Parker 2002)

Gaya atau energi yang memberikan kontribusi terbesar adalah dari aliran air(tegangan geser) terutama untuk angkutan 
sedimen dasar (bed load), selanjutnya turbulensi aliran berperan dalam membentuk angkutan sedimen melayang (suspensi). Pada partikel koloid yang lebih berperan adalah interaksi ionik dari dalam geraksecara acak brown.

Angkutan sedimen (sediment transport) adalah mekanisme pemindahan butiran sedimen dari tempat yang disebabkan adanya aliran air. Kecepatan perpindahan sedimen dan volume sedimen peratuan waktu disebut debit sedimen.

Proses angkutan sedimen dapat dilihat pada gambar berikut :

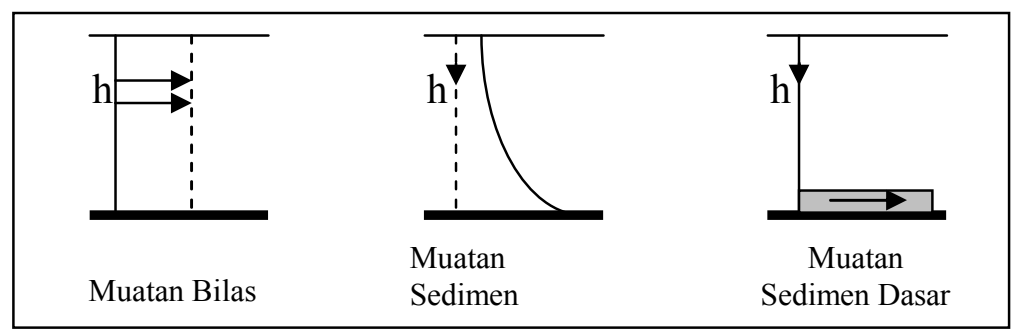

Gambar 8-2. Klasifikasi angkutan sedimen

Faktor-faktor yang Mempengaruhi Angkutan Sedimen

Sedimen yang terangkut oleh air dipengaruhi oleh :

\section{Ukuran Partikel Sedimen}

Menurut besarnya ukuran sedimen dapat digolongkan seperti tabel berikut ini: 
Tabel 8-1. Klasifikasi Ukuran Butir

\begin{tabular}{|c|l|l|}
\hline No. & \multicolumn{1}{|c|}{ Klasifikasi } & \multicolumn{1}{|c|}{ Ukuran Butir } \\
\hline 1. & Bongkah (Boulder) & $>256 \mathrm{~mm}$ \\
2. & Berangkal (Couble) & $64-256 \mathrm{~mm}$ \\
3. & Kerikil (Gravel) & $2-64 \mathrm{~mm}$ \\
4. & Pasir (Sand) & $62-2000 \mu \mathrm{m}$ \\
5. & Lanau (Silt) & $4-62 \mu \mathrm{m}$ \\
6. & Lempung (Clay) & $<4 \mu \mathrm{m}$ \\
\hline
\end{tabular}

Ackers-White dan Yalin mendefinisikan parameter butir adalah :

a. Diameter partikel :

$$
D^{*}=D_{50}\left[\frac{(S-1) g}{v^{2}}\right]^{1 / 3}
$$

Dimana

$\mathrm{D}_{50}=$ Diameter median dari material dasar

$\mathrm{S}=$ kerapatan jenis

$\mathrm{V}=$ Koefisien kekentalan kinematic

b. Transport Stage Parameter

$$
T=\frac{\left(U^{*} !\right)^{2}-\left(u * \cdot U_{r}\right)^{2}}{\left(U^{*} \cdot U_{r}\right)^{2}}
$$




$$
\begin{array}{ll}
\mathrm{U}^{*}, & =\left(\mathrm{g}^{0,5} / \mathrm{C}^{\prime}\right) . \mathrm{U} \\
\mathrm{C}^{\prime} & =\text { Koefisien Chezy } \\
\mathrm{u}^{\prime} & =\text { Kecepatan rata-rata }
\end{array}
$$

\section{Bentuk Partikel}

Bentuk partikel juga berpengaruh pada perhitungan angkutan sedimen, yaitu pada kecepatan angkutan butir. NC Nown da Malaika dan Alberton mempelajari bentuk partikel dan memberikan suatu definisi yang dapat digunakan secara praktis dan menghasilkan hasil yang cukup baik. Faktor bentuk tersebut dinyatakan dalam :

$$
\mathrm{SF}=\mathrm{c} /(\mathrm{a} \cdot \mathrm{b})^{0,5}
$$

$$
\begin{aligned}
\mathrm{SF} & =\left(\mathrm{g}^{0,5} / \mathrm{C}^{\prime}\right) . \mathrm{U} \\
\mathrm{a} & =\text { penampang terpanjang dari partikel }(\mathrm{mm}) \\
\mathrm{b} & =\text { penampang dari partikel }(\mathrm{mm}) \\
\mathrm{c} & =\text { penampang terpendek dari partikel }(\mathrm{mm})
\end{aligned}
$$

\section{Berat Spesifik Partikel Sedimen}

Definisi Berat Spesifik (Spesific Weight) ialah berat persatuan volume dari bahan angkutan sedimen.

$$
\gamma=\frac{\text { BeratSedimen }}{\text { VolumeSedimen }}
$$

Untuk menghitung kecepatan angkut partikel diasumsikan bahwa : 
a. Partikel adalah Sperical (bulat)

b. Gaya percepatan fluida orde dua.

Distribusi kecepatan vertikal digunakan rumus :

$$
u(z)=\frac{u^{*}}{k} \ln \left(\frac{z}{z_{o}}\right)
$$

dimana : $\quad \mathrm{u}^{*} \quad=$ kecepatan geser dasar

$\mathrm{z}=0,05 \mathrm{~h}$

$\mathrm{K}=$ konstanta Von Karman $=(0,4)$

$\mathrm{z}_{\mathrm{o}}=0,11\left(\mathrm{v} / \mathrm{u}^{*}+0,03 \mathrm{ks}\right)$

$\mathrm{k}_{\mathrm{s}} \quad=$ kekasaran nikuradse

Rumus-rumus perhitungan angkutan sedimen baik mengenai Bed Load, maupun suspended Load yang diperoleh dari beberapa bentuk model fisik untuk meramalkan hubungan antara parameter-parameter yang mempengaruhi angkutan sedimen.

\subsection{Angkutan sedimen dasar}

\section{A. Schoklitsch's $(1934,1943)$}

Peneliti pertama yang menggunakan pendekatan debit efektif, yaitu debit airdikurangi debit kritis qc (debit pada kondisi mulai bergeraknya sedimen) sebagaifaktor dominan transport sedimen.

Satuan persamaan adalah metric

Persamaan tahun 1934 


$$
\begin{aligned}
& q_{b}=\frac{7000}{d^{0.5}} S^{3 / 2}\left(q-q_{c}\right) \\
& q_{c}=\frac{1.94410^{-5} d}{S^{4 / 3}}
\end{aligned}
$$

Persamaan tahun 1943

$$
\begin{aligned}
& q_{b}=\frac{2500}{d^{0.5}} S^{3 / 2}\left(q-q_{c}\right) \\
& q_{c}=\frac{0.6 d^{3 / 2}}{S^{4 / 3}}
\end{aligned}
$$

\section{B. Kalinske (1947)}

Transport sedimen merupakan fungsi dari kecepatan sesaat $\mathrm{u}_{\mathrm{s}}$ saat nilainyamelebihi kecepatan rata-rata kritik $\mathrm{V}_{\mathrm{s}}$ (kecepatan saat awal butiran bergerak). Pada kondisi aliran turbulen rerata kecepatan sesaat merupakan fungsi dari rasiotegangan geser kritik dan tegangan geser dasar saluran. Maka dapat diturunkan persamaan empiris berikut

$$
\frac{q_{b}}{U_{*} d}=f^{\prime}\left(\frac{\tau_{c}}{\tau}\right)
$$

$$
\begin{gathered}
\text { Dimana }: \\
\mathrm{qb}=\text { sedimen dasar }(\mathrm{kg} / \mathrm{s}) / \mathrm{m} \text { lebar } \\
\tau \mathrm{c}=\text { tegangan geser } \mathrm{kritik} \\
\mathrm{U}^{*}=\text { kecepatan geser air }
\end{gathered}
$$

\section{Meyer Peter Muller (1948)}

Transport sedimen merupakan fungsi dari dari energi hilang dari aliran dalam proporsi kemiringan energi $($ energy slope $=(\mathrm{Ks} / \mathrm{Kr}) \mathrm{S})$ 
Data adalah dalam satuan metrik adalah : Diameter butiran dominan $\mathrm{d}(\mathrm{m})$, tinggi kekasaran $=\mathrm{d}_{90}(\mathrm{~m})$, debit aliran $\mathrm{qm}^{3} /$ det, dan kemiringan energi aliran $\mathrm{S}$, jari-jari basah R (m), $\square \mathrm{s}$ berat jenissedimen (ton $/ \mathrm{m}^{3}$ ), q debit sedimen hasil dalam satuan ton/detik per satuanlebar .

$$
\begin{gathered}
\gamma\left(\frac{K_{s}}{K_{r}}\right)^{3 / 2} R S=0.0407\left(\gamma_{s}-\gamma\right) d+0.25 \rho^{1 / 3} q_{b}^{2 / 3} \\
K_{r}=\frac{26}{d_{90}^{1 / 6}} \quad S_{r}=\frac{V^{2}}{K_{r}^{2} R^{4 / 3}} \\
\left(\frac{K_{s}}{K_{r}}\right)^{3 / 2}=\frac{S_{r}}{S}
\end{gathered}
$$

\section{Rottner (1959)}

Mengasumsikan transport sedimen didominasi fungsi dari kekasaran relatif $\mathrm{d}_{50} / \mathrm{D}$ berdasarkan analisis dimensi dan melakukan regresi dari penelitian di sungaidan di laboratorium

$$
q_{b}=\gamma_{s} \sqrt{\left(\varsigma_{s}-1\right) g D^{3}}\left(\frac{V}{\sqrt{\left(\varsigma_{s}-1\right) g D}}\left(0.667\left(\frac{d_{50}}{D}\right)^{2 / 3}+14\right)-0.778\left(\frac{d_{50}}{D}\right)^{2 / 3}\right)^{3}
$$

Dimana:

Satuan persamaan menggunakan satuan english

$\mathrm{qb}=$ dalam satuan berat kering sedimen per detik $(\mathrm{lb} / \mathrm{s}) / \mathrm{ft}$

$\mathrm{d}_{50}=$ diameter butiran, kedalaman rerata dalam $\mathrm{ft}$

$\zeta=$ massa jenis $=\gamma \mathrm{s} / \gamma$

$\mathrm{V}=$ Kecepatan rata-rata $\mathrm{ft} / \mathrm{sec}$

$\mathrm{g}=$ grafitasi $=62,4 \mathrm{ft} / \mathrm{sec}^{2}$. 


\section{E. Einstein Bed Load (1950), Original}

Einstein, transport sedimen sulit didekati dari awal gerakan butiran, lebihmerupakan fungsi turbulensi aliran sehingga awal gerak butiran diturunkansebagai fungsi probabilistik.Einstein menggunakan hanya tegangan geser dasar oleh kekasaran butiran sajayang dipakai sehingga harus memisahkan komponen tegangan geser dasar olehformasi dasar dari total tegangan geser.

Cari nilai jari-jari hidraulis karena kekasaran dasar $\mathrm{R} \square$

$\mathrm{R}^{\prime}$

\section{Asumsikan nilai jari-jari hidraulis karena kekasaran dasar (skin roughness)}

Hitung kecepatan geser butiran oleh kekasaran dasar (skin fricton) $U_{*}^{\prime}=\sqrt{g R^{\prime} S}$

Hitung tebal sub lapis laminer $\delta=\frac{11.6 v}{U_{*}}$

Hitung kekasaran relatif terhadap lapis sub laminer $\frac{k_{s}}{\delta}=\frac{d_{65}}{\delta}$

Cari koreksi distribusi logaritmik $\mathbf{x}$ dari $k_{s} / \delta$ dan grafik 26

\section{F. Einstein Bed Load (1957), Size fraction method by}

\section{Vanoni \& Brooks}

Rumusan asli dari Einstein- Barbarosa dalam perhitungan R' masih kurangpraktis karena membutuhkan coba-coba berulang kali, maka untuk menyelesaikan secara langsung persamaan untuk memperoleh $U_{*}$ ' disusun grafik baru Gambar 8-3 oleh Vanoni - Brooks, selanjutnya grafik ini diperluas oleh Simons dan Senturk 1976 


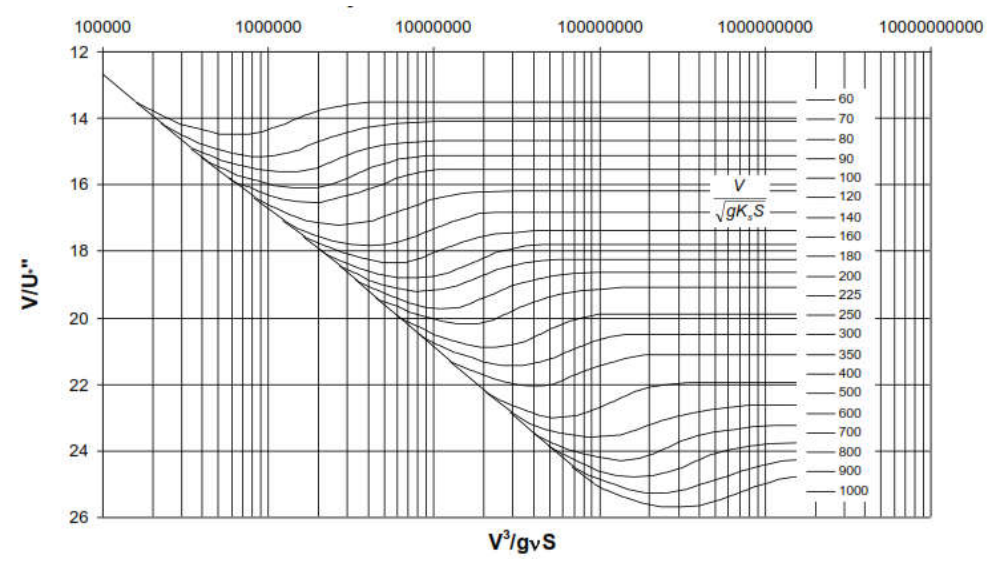

Gambar 8-3. Grafik U* oleh Vanoni - Brooks

8.2.1 Analisa Angkutan Sedimen Suspensi dengan Metode

Sesaat

Angkutan sedimen layang yang terjadidihitung dengan rumus :

$$
Q_{s}=0,0864 . C \cdot Q_{w}
$$

Dimana: Qs $=$ debit angkutan sedimen (ton/hari)

$\mathrm{C}=$ konsentrasi sedimen $(\mathrm{mg} / \mathrm{ltr})$

$\mathrm{Qw}=$ debit sungai $(\mathrm{m} 3 / \mathrm{det})$

Apabila dalam periode 1 hari dilaksanakan pengukuran aliran dapat dihitung dengan persamaan sebagai berikut :

$$
\overline{Q_{w}}=\frac{1}{24} \sum_{1}^{n} Q_{1} \Delta t_{i}
$$

dimana : $\quad \overline{Q_{w}}=$ besar aliran harian rata-rata $(\mathrm{m} 3 /$ det $)$

Q1 = besar aliran yang terukur pada saat sub I (m3/det)

$\Delta \mathrm{ti}=$ interval waktu pengukuran aliran (jam)

$\mathrm{n} \quad=$ jumlah pengukuran aliran 
Sedang rata-rata konsentrasi sedimen harian dapat dihitung dengan persamaan sebagai berikut :

$$
\bar{C}=\frac{1}{24} \sum_{1}^{n} c_{i} \Delta t_{i}
$$

$$
\begin{aligned}
\operatorname{dimana}: \bar{C} & =\text { konsentrasi rata-rata sedimen harian }(\mathrm{mg} / \mathrm{l}) \\
\mathrm{c}_{\mathrm{i}} & =\text { konsentrasi sedimen pada saat } \mathrm{t}_{\mathrm{i}}(\mathrm{mg} / \mathrm{l}) \\
\Delta \mathrm{t}_{\mathrm{i}} & =\text { interval waktu pengukuran }(\mathrm{jam}) \\
\mathrm{n} & =\text { jumlah pengukuran }
\end{aligned}
$$

Oleh karena Qi dan Ci, kedua-duanya tidak tetap selama periode waktu 24 jam, maka besarnya rata-rata debit sedimen hariannya dihitung dengan persamaan sebagai berikut :

$$
Q_{s}=\sum_{1}^{n} \frac{0,0864 C_{i} Q_{w i}}{24} \Delta t_{i}
$$

$$
\begin{aligned}
\text { dimana: Qs } & =1 \text { rata-rata debit sedimen harian (ton/hari) } \\
\mathrm{ci} & =\text { konsentrasi sedimen pada saat ti }(\mathrm{mg} / \mathrm{l}) \\
\text { Qwi } & =\text { besar aliran pada saat ti }(\mathrm{m} 3 / \mathrm{det}) \\
\Delta \mathrm{ti} & =\text { interval waktu pengukuran }(\mathrm{jam}) \\
\mathrm{n} & =\text { jumlah pengukuran }
\end{aligned}
$$

Hasil akhir dari persamaan di atas akan berbeda dengan nilai debit sedimen yang dihitung dengan persamaan : Qs = 0,0864. C. Qw

\subsection{Analisa Angkutan Sedimen dengan Metode L.C. Van Rijn}

Muatan sedimen layang bergerak bersama dengan aliran air sungai disamping itu dalam sedimen layang juga terdapat sedimen bilas (wash load) yang berukuran sangat kecil $(<50$ 
mikro meter). Bagian ini akan diuraikan metode perhitungan sedimen layang berdasarkan kajian yang sebelumnya dilakukan oleh Van Rijn.

Untuk menghitung sedimen layang, maka perlu diketahui parameter partikel $\left(\mathrm{D}_{0}\right)$

$$
D_{o}=D_{50}\left[\frac{(S-1) g}{v^{2}}\right]^{1 / 3}
$$

dimana :

$\mathrm{D}_{50}=$ diameter median dari material dasar

$\mathrm{S}=$ kerapatan jenis

$v \quad=$ koefisien kekentalan kinematik

Stage parameter $(\mathrm{T})$

$$
T=\frac{\left(U_{0}\right)^{2}-\left(U_{0 c r}\right)^{2}}{\left(U_{o c r}\right)^{2}}
$$

dimana $: U_{o}^{!}=\frac{\sqrt{g}}{C^{!}} \mathrm{U}=$ kecepatan geser dihubungkan dengan ukuran butiran

$$
C^{!}=18 \log \left(\frac{12 R_{b}}{3 D_{90}}\right)
$$

Dimana: $\quad \mathrm{R}_{\mathrm{b}}=$ jari-jari hidraulis.

$\mathrm{U}_{\text {ocr }}=$ kecepatan geser pada dasar sungai menurut Shields.

$\bar{U} \quad=$ kecepatan aliran rata-rata

Dalam Perhitungan skripsi nilai $\mathrm{R}_{\mathrm{b}}=\mathrm{y}$ karena menurut Robert J Kodoatie apabila sungai lebar maka nilai $R_{b}=y$ 
Parameter suspensi yang menyatakan pengaruh gaya air turbulen arah ke atas dan ke bawah :

$$
z=\frac{w_{s}}{\beta \chi U_{o}}
$$

Selain itu diperkenalkan tinggi acuan (a) dimana konsentrasi sedimen dasar digunakan sebagai acuan. Tinggi acuan (a) dinyatakan sebagai :

$\mathrm{a}=0,5 \Delta$ atau $\mathrm{a}=\mathrm{k}_{\mathrm{s}}\left(\mathrm{a}_{\min }=0,01 \mathrm{~d}\right)$

Selanjutnya dihitung konsentrasi acuan (Ca), didekati dengan :

$$
C_{a}=0,015 \frac{D_{50} T^{1,5}}{a D_{s}^{0,3}}
$$

Tahap selanjutnya adalah menghitung ukuran partikel sedimen layang (Ds), yang dinyatakan sebagai :

$$
\frac{D_{s}}{D_{50}}=1+0,011\left(\sigma_{s}-1\right)(T-25)
$$

dimana $: \sigma_{s}=\frac{-}{2}\left[\frac{D_{84}}{D_{50}}+\frac{D_{16}}{D_{50}}\right]$

Tahap selanjutnya adalah menghitung kecepatan jatuh (WS) sedimen layang.Untuk kondisi yang relatif tenang dan relatif jernih serta ukuran partikel $<100 \mu \mathrm{m}$ maka :

$w_{s}=\frac{1}{18} \frac{(s-1) g D_{s}^{2}}{v}$ (menurut Stokes) 
untuk partikel berukuran $100-1000 \mu \mathrm{m}$

$$
W_{s}=10 \frac{v}{D_{s}}\left\{\left[1+\frac{0,01(s-1) g D_{s}^{3}}{v^{2}}\right]^{y}-1\right\}
$$

untuk partikel lebih besar lagi

$$
W_{s}=1,1\left[(S-1) g D_{s}\right]^{0,5}
$$

Tahap selanjutnya adalah menghitung $\beta$-faktor (menurut Kikkowa)

$$
\beta=1+2\left[\frac{W_{s}}{U_{o}}\right]^{2} \text { untuk } 0,1<\frac{W_{s}}{U_{o}}<1
$$

Kecepatan geser dihitung $\mathrm{U}_{\mathrm{o}}=\sqrt{g d s}$ Selanjutnya menghitung $\varphi$ - faktor, yaitu faktor koreksi yang menampung semua pengaruh tambahan pada bilangan suspensi akibat adanya tempat-tempat yang diisi partikel, reduksi kecepatan jatuh dan lain-lain.

$$
\varphi=2,5\left[\frac{W_{s}}{U_{o}}\right]^{0,8}\left[\frac{C_{a}}{C_{o}}\right]^{0,4} \text { untuk } 0,01 \leq \frac{W_{s}}{U_{o}} \leq 1
$$

Tahap berikutnya menghitung parameter suspensi z dan $\mathrm{z}^{!}$ 


$$
z=\frac{W_{s}}{\beta \chi U_{o}}
$$

$\mathrm{z} !=\mathrm{z}+\varphi$

Tahap berikutnya menghitung $\mathrm{F}$ - faktor

$$
F=\frac{\left[\frac{a}{d}\right]^{z^{!}}-\left[\frac{a}{d}\right]^{1,2}}{\left[1-\frac{a}{d}\right]^{z^{!}}\left(1,2-z^{!}\right)}
$$

Total sedimen layang ( suspended load ) permeter lebar :

$$
\mathrm{q}_{\mathrm{s}}=\text { F.U.d.C } \mathrm{a}_{\mathrm{a}} \quad\left(\mathrm{m}^{3} / \operatorname{det} \text { per } \mathrm{m} \text { lebar }\right)
$$

Dimana :

$$
\begin{aligned}
& \mathrm{F}=\text { faktor koreksi } \\
& \mathrm{U}=\text { kecepatan aliran rata-rata }\left(\mathrm{m}^{2} / \text { det }\right) \\
& \mathrm{d}=\text { kedalaman aliran }(\mathrm{m}) \\
& \mathrm{C}_{\mathrm{a}}=\text { konsentrasi }(\mathrm{mg} / \mathrm{ltr})
\end{aligned}
$$

Sedimen Dasar (Bed Load) merupakan angkutan partikel sedimen yang disebabkan oleh daya seret air lebih besar dibanding gaya berat sedimen, sehingga sedimen bergerak dapat berupa menggelinding, bergeser atau dengan meloncat-loncat pada dasar saluran. Bed Load transport (qb) adalah merupakan perkalian antara kecepatan partikel (ub ), dengan tinggi loncatan $(\delta b)$ dan konsentrasi dari bed load (cb), jadi :

$$
\mathrm{q}_{\mathrm{b}}=\mathrm{c}_{\mathrm{b}} \cdot \mathrm{u}_{\mathrm{b}} \cdot \delta_{\mathrm{b}}
$$




$$
\mathrm{c}_{\mathrm{b}} \quad=\quad \mathrm{c}_{\mathrm{o}} \cdot 0,18 \frac{T}{D^{*}}
$$

$\mathrm{c}_{\mathrm{o}}=0,65$

$$
\mathrm{u}_{\mathrm{o}}=1,5\left(\Delta \mathrm{gd}_{50}\right)^{0,5} \mathrm{~T}^{0,6}
$$

$$
\delta_{\mathrm{b}} \quad=\quad 0,117 \mathrm{D}^{*-1} \mathrm{~T}
$$

dimana :

$$
\begin{aligned}
& \mathrm{D}_{*}=\mathrm{d}_{50 \cdot\left(\frac{\Delta g}{U^{2}}\right)^{1 / 3}=\text { parameter partikel (-) }} \\
& \mathrm{T}=\frac{\left(u^{* \prime}\right)^{2}-\left(u_{>c r}^{*}\right)^{2}}{\left(u_{>c r}^{*}\right)^{2}}=\text { transport stage parameter }(-) \\
& \mathrm{u} *=\left(\mathrm{g}^{0,5} / \mathrm{C}^{\prime}\right) \mathrm{u}=\text { kecepatan geser dasar efektif }
\end{aligned}
$$
dihubungkan dengan butir $(\mathrm{m} / \mathrm{s})$

$$
\begin{aligned}
& \Delta=\left(\rho_{\mathrm{s}}-\rho\right) / \rho=\text { berat relatif }(-) \\
& \mathrm{C}^{\prime}=18 \log \left(\frac{12 h}{3 d_{90}}\right)=\text { koefisien Chezy berhubungan }
\end{aligned}
$$

dengan butir $\left(\mathrm{m}^{0,5} / \mathrm{s}\right)$

$\overline{\mathrm{u}}=$ kecepatan aliran pada kedalaman rata-rata $(\mathrm{m} / \mathrm{s})$

$\mathrm{d}_{50}, \mathrm{~d}_{90}=$ diameter partikel dari material dasar $(\mathrm{m})$

$\mathrm{v}=$ koefisien viscositas kenematik $\left(\mathrm{m}^{2} / \mathrm{s}\right)$

$\mathrm{g}=$ percepatan gravitasi $\left(\mathrm{m} / \mathrm{s}^{2}\right)$

$$
q b=0,053(\Delta g) 0,5 d 501,5 D^{*}-0,3 T 2,1
$$

$\mathrm{qb}=$ Bed load transport pada satu satuan lebar $\left(\mathrm{m}^{3} / \mathrm{s}\right)$ 
8.4 Analisa Angkutan Sedimen Dengan Metode Peter-MeyerMuller

Persamaan ini didukung oleh data laboratorium mekanika tanah dari grafik analisa butiran dari contoh endapan, yaitu diameter partikel yang melalui saringan $\mathrm{D}_{50}(\mathrm{~mm}), \mathrm{D}_{90}(\mathrm{~mm})$, rapat massa sedimen $\left(\mathrm{kg} / \mathrm{m}^{3}\right)$ dan angka pori. Selanjutnya langkah perhitungan adalah sebagai berikut :

Koefisien-koefisien de Chezy :

$$
\begin{aligned}
& \mathrm{C}=\frac{\overline{\mathrm{U}}}{\sqrt{\mathrm{hI}}} \\
& \mathrm{C}^{\prime}=18 \log \frac{12 \mathrm{~h}}{\mathrm{D}_{90}} \\
& \mu=\text { ripple factor } \\
& \mu=\left[\frac{\mathrm{c}}{\mathrm{C}^{\prime}}\right]^{1,5} \\
& \mu=\left[\frac{\overline{\mathrm{U}}}{\sqrt{\mathrm{hI}}}\right]^{1,5} \\
& \psi^{\prime}=\frac{\mu \mathrm{hI}}{\Delta \mathrm{D}_{50}}
\end{aligned}
$$




$$
\psi^{\prime}=\frac{\left[\frac{\overline{\mathrm{U}}}{\frac{\sqrt{\mathrm{hI}}}{18 \log \frac{12 \mathrm{~h}}{\mathrm{D}_{90}}}}\right]^{1,5}}{\Delta \mathrm{D}_{50}}
$$

$\Delta=\rho_{\mathrm{s}}-\rho_{\text {air }}$

$$
\begin{gathered}
\mathrm{Sb}=\frac{8 \sqrt{\Delta \mathrm{g} \mathrm{D}_{50}}}{1-\varepsilon} \quad\left(\Psi^{\prime}-0,047\right)^{3 / 2} \\
\varepsilon \quad=\text { void ratio }=0,4 \\
T=\frac{S b A}{h} x\left(24 \times 3600 \mathrm{~m}^{3} / \text { hari }\right)
\end{gathered}
$$

dimana :

$\mathrm{T}=$ tansport sedimen (m3/hari)

ps $=$ rapat massa sedimen $(\mathrm{kg} / \mathrm{m} 3)$

pair $=$ rapat air $(\mathrm{kg} / \mathrm{m} 3)$

$\mathrm{g}=$ percepatan gravitasi bumi $(=9,81 \mathrm{~m} / \operatorname{det} 2)$

$\mathrm{D}_{50}=$ diameter partikel sedimen yang tertahan pada saringan $(\mathrm{mm})$

$\overline{\mathrm{U}}=$ kecepatan rata-rata aliran $(\mathrm{m} / \mathrm{det})$

$\mathrm{I}=$ pelandaian memanjang

$\mathrm{A}=$ luas penampang basah (m2)

$\mathrm{h}=$ kedalaman air $(\mathrm{m})$

$24 \times 3600=$ waktu dalam detik untuk 1 hari pengaliran. 


\section{Soal Latihan 5}

1. Uraikan perbedaan bed load transport dan suspended load transpor, serta bagaimana dampaknya terhadap kelestarian sungai?

2. Jika kecepatan aliran sebesasar $2,2 \mathrm{~m} /$ det dan diameter sedimen $\mathrm{d} 90=1,2 \mathrm{~mm}$, berapakah besarnya kecepatan aliran sebesasar 2,2 $\mathrm{m} /$ det dan diameter sedimen $\mathrm{d} 90=1,2 \mathrm{~mm}$, berapakah besarnya transpor sedimen? Gunakan 3 rumus sebagai pembanding.

3. Dari evaluasi sedimen sungai Palu, diketahui bahwa umumnya sedimen bercampur dalam beberapa ukuran, yang manakah dimaksud $\mathrm{d}_{50}$ ? 


\section{MODUL 9. KERUSAKAN SUNGAI}

1. Sasaran Pembelajaran

- Mahasiswa dapat mengetahui serta memahamikerusakan dan pengamanan sungai

- Mahasiswa dapat mengetahui langkah pengamanan sungai.

2. Kemampuan yang mahasiswa yang menjadi prasyarat Hidrolika, Hidrologi dan pengembangan sumber daya air.

3. Keterkaitan bahan pembelajaran dengan pokok bahasan lainnya sangat berkaitan dan merupakan satu kesatuan yang saling menunjang

4. Manfaat atau pentingnya bahan pembelajaran ini yaitu mahasiswa mampu memahami kerusakan dan pengamanan pantai serta pengendalian banjir.

5. Petunjuk belajar mahasiswa, penjelasan tentang hal hal yang perlu dilakukan mahasiswa dalam mempelajari materi ini yaitu dengan menampilkan beberapa contoh dan gambar serta memberi tugas mencari paper di internet sehingga akan memperkaya wawasan mereka.

\subsection{Kerusakan dan Pengaman Sungai}

Sungai merupakan salah satu saluran drainase yang terbentuk secara alami. Sementara itu aliran mengakibatkan proses penggerusan dasar sungai. Aliran sungai tersebut bisa menyebabkan erosi. Jika batuan penyusun tebing sungai tidak kompak maka pengikisan tanah sangat mudah terjadi dan dalam jangka yang panjang dapat mengakibatkan kelongsoran. Oleh karena itu diperlukan adanya konstruksi pelindung tebing sungai 
agar tidak terjadi pendangkalan akibat gerusan oleh air terhadap tebing sungai.

\subsection{Indikator Komponen Aspek Dinamik Morpologi Sungai}

Sungai pada umumnya merupakan perpaduan dari ketiga tipe tersebut. Banyaknya anak-anak sungai dalam suatu DAS ditentukan dengan index kerapatan sungai yang dikemukakan oleh Neumann. Kerapatan sungai adalah suatu indek yang menunjukkan banyaknya anak sungai dalam suatu daerah pengaliran.

Kerapatan Sungai

$$
=\frac{\text { Panjang Total Sungai Utama dan anak anaknya }}{\text { Luas Daera Pengaliran }}
$$

Harganya berkisar antara 0,30 sampai 0,50 dan dianggap sebagai indek yang menunjukkan keadaan topografi dan geologi dalam daerah pengaliran. (Sosrodarsono, Suyono: Takeda, Kensaku, 1980).

Erosi sungai/saluran ini harus ditinjau secara terpisah dari tipe-tipe erositelah dipelajari sebelumnya yang diakibatkan oleh air hujan. Erosi pada tebing sungai yang berlangsung teus menerus akan menyebabkan meandering. 


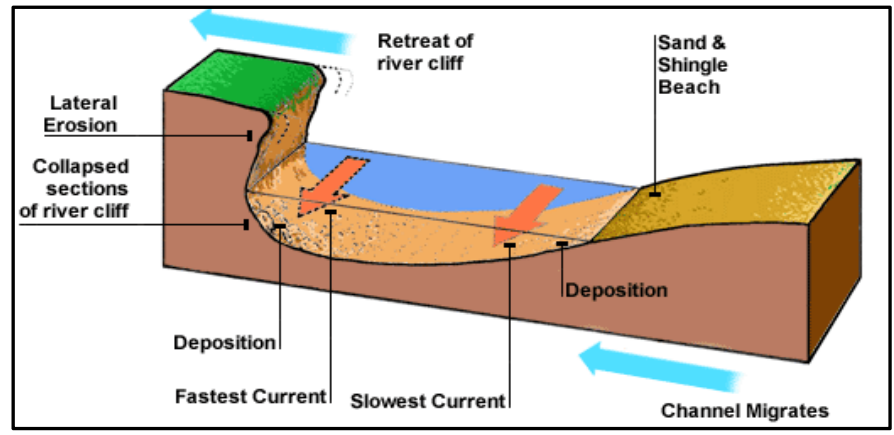

Gambar 9-1. Potongan melintang pada saluran sungai Sumber : BBC.co.uk/hydrosphere, 2014

Gerusan adalah fenomena alam yang terjadi karena erosi terhadap aliran air pada dasar dan tebing saluran sungai. Gerusan umum (general scour), gerusan yang terjadi akibat dari proses alam dan tidak berkaitan sama sekali dengan ada tidaknya bangunan sungai.

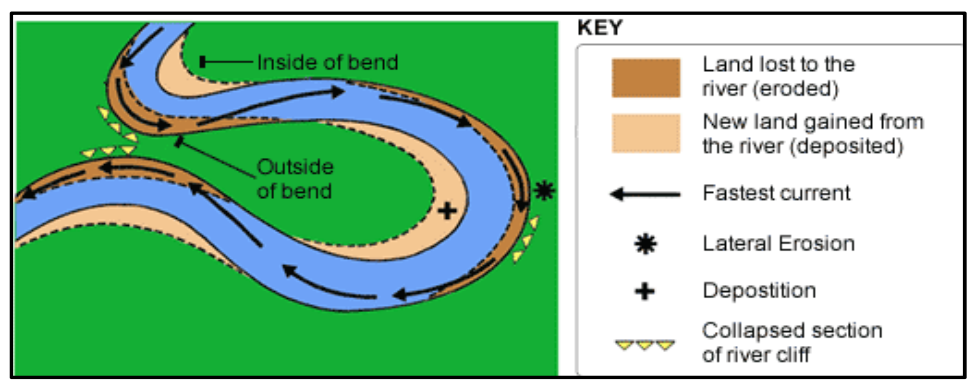

Gambar 9-2. Perubahan bentuk meander Sumber : BBC.co.uk/hydrosphere, 2014

\subsection{Kerusakan Sungai dan Bangunan Pengaman Sungai}

Gejala air mengalir dapat memiliki sifat-sifat laminer, turbulen, pusaran, loncatan dan sebagainya. Air mengalir 
diakibatkan adanya perbedaan tinggi suatu wilayah. Pengaliran itu berupa tenaga angkut dan tenaga angkat sedimen. Angkutan sedimen itu dapat berupa muatan dasar dan muatan layang. Aliran sungai bersifat sembarang bergantung pada kondisi alam. Langkah Pengaman Sungai

Bangunan pengaman tebing sungai bertujuan untuk menahan tanah agar tidak longsor, bahan konstruksi untuk dinding penahan yaitu : dari kayu, beton, pasangan batu, dan dari baja.Untuk merencanakan sebuah dinding penahan tanah perlu diperhatikan syarat kestabilitasan dinding. Berdasarkan bentuk dan penahan terhadap tanah, dinding penahan dapat diklasifikasikan ke dalam tiga bentuk, yakni : dinding gravity, dinding semi gravity dan dinding non gravity.

Prasarana bangunan pengendali banjir berfungsi sebagai penyalur dan pengatur air banjir. Bentuk bangunan pengendali banjir antara lain berupa:Pelindung Tebing; Pengarah arus; Tanggul; Dam penahan sedimen dan Groundsill.

Beberapa jenis pelindung tebing diantaranya adalah sebagai berikut :

a. Gebalan Rumput

Gebalan rumput berfungsi sebagai pelindung lereng terhadap hempasan air hujan sehingga mencegah erosi atau longsoran.

b. Bronjong Kawat

Batu Kali yang dipasang secara rapi kemudian pada bagian luarnya dibungkus oleh kawat-kawat. 


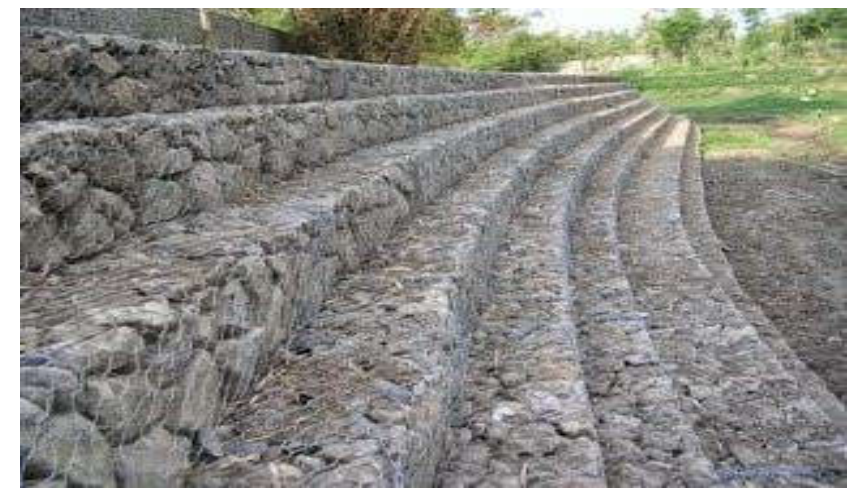

Gambar 9-3.Bronjong kawat

c. Blok Beton

Blok beton dengan ukuran tertentu sesuai dengan kebutuhan dilapangan. Blokbeton dirangkai satu dengan yang lainnya seperti terlihat pada gambar berikut :
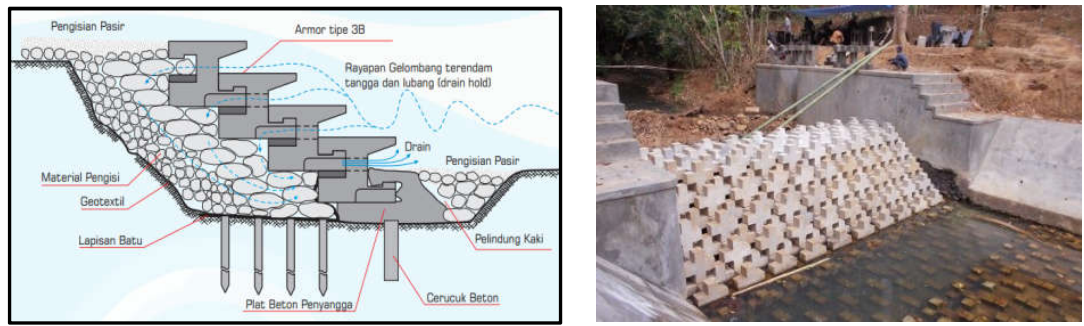

Gambar 9-4. Blok beton

d. Pasangan Batu

Pasangan batu secara umum sudah diketahui dan untuk pekerjaan pengamanan tebing sungai selalu mengikuti kondisi sungai seperti gambar berikut : 

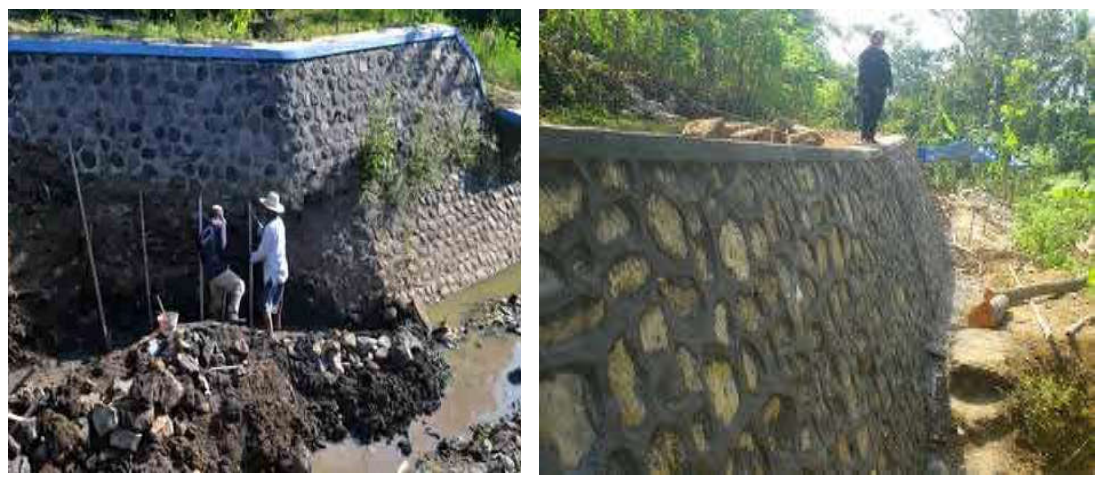

Gambar 9-5. Pasangan batu 


\section{MODUL 10. PENGENDALIAN BANJIR SUNGAI}

1. Sasaran Pembelajaran

- Mahasiswa dapat mengetahui serta memahami banjir sungai

- Mahasiswa dapat mengetahui langkah pengendalian banjir sungai.

2. Kemampuan yang mahasiswa yang menjadi prasyarat Hidrolika, Hidrologi dan pengembangan sumber daya air.

3. Keterkaitan bahan pembelajaran dengan pokok bahasan lainnya sangat berkaitan dan merupakan satu kesatuan yang saling menunjang

4. Manfaat atau pentingnya bahan pembelajaran ini yaitu mahasiswa mampu memahami kerusakan dan pengamanan pantai serta pengendalian banjir.

5. Petunjuk belajar mahasiswa, penjelasan tentang hal hal yang perlu dilakukan mahasiswa dalam mempelajari materi ini yaitu dengan menampilkan beberapa contoh dan gambar serta memberi tugas mencari paper di internet sehingga akan memperkaya wawasan mereka..

10.1 Banjir dan Penyebabnya

Pengendalian banjir bertujuan untuk mengantisipasi air berlebih yang emnggenangi suatu kawasan. Peristiwa banjir kadang tidak bermasalah jika tidak mengganggu kepentingan manusia.

Menurut Kodoatie dan Sugiyanto (2002), faktor penyebab terjadinya banjir dapat diklasifikasikan dalam dua kategori, yaitu banjir alami dan banjir oleh tindakan manusia. Banjir 
akibat alami dipengaruhi oleh curah hujan, fisiografi, erosi dan sedimentasi, kapasitas sungai, kapasitas drainase danpengaruh air pasang. Sedangkan banjir akibat aktivitas manusia disebabkan karena ulah manusia yang menyebabkan perubahanperubahan lingkungan seperti: perubahan kondisi daerah aliran sungai (DAS).

Faktor penyebab banjir yaitu Curah Hujan, Pengaruh fisiografi (geografi fisik sungai seperti bentuk, fungsi dan kemiringan daerah pengaliran sungai (DPS), kemiringan sungai, geometrik hidrolik (bentuk penampang seperti lebar, kedalaman, potongan memanjang, material dasar sungai). Dan yang terakhir adalah Erosi dan Sedimentasi dan Kapasitas sungai.

Faktor Penyebab banjir akibat tindakan manusia yaitu Perubahan kondisi DPS, Kawasan kumuh, Sampah, Drainasi lahan, Bendung dan bangunan air, Kerusakan bangunan pengendali air dan yang terakhir adalah Perencanaan sistem pengendalian banjir tidak tepat

\subsection{Pengendalian Banjir}

Secara umum pengendalian banjir sangat diharapkan dengan melibatkan masyarkat, pemerintah dan beberapa stakeholder. Berdasarkan kajian dibentuk skema pengendalian banjir secara teknis dan non teknis sebagai berikut : 


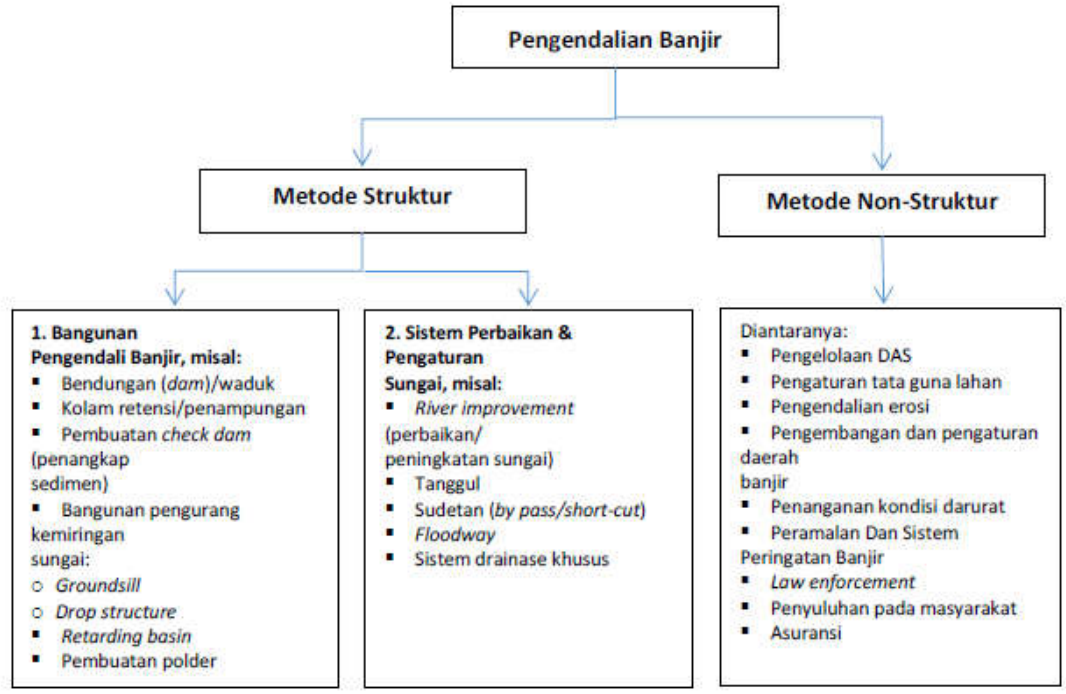

Gambar 10-1.Skema pengendalian banjir

\section{Soal Latihan 6}

1. Uraikan Secara komprehensip penanganan sungai jika diketahui terjadi longsoran tebing dan banjir yang cukup besar? Diskusi 


\section{MODUL 11. PARAMETER HIDROLIKA SUNGAI}

1. Sasaran Pembelajaran

- Mahasiswa dapat mengetahui serta memahami parameter hidrolika

- Mahasiswa dapat mengetahui energispesifik, sifat-sifat aliran kritis.

2. Kemampuan yang mahasiswa yang menjadi prasyarat Hidrolika, Hidrologi dan pengembangan sumber daya air.

3. Keterkaitan bahan pembelajaran dengan pokok bahasan lainnya sangat berkaitan dan merupakan satu kesatuan yang saling menunjang

4. Manfaat atau pentingnya bahan pembelajaran ini yaitu mahasiswa mampu memahami distribusi kecepatan, konservasi energi .

5. Petunjuk belajar mahasiswa, penjelasan tentang hal hal yang perlu dilakukan mahasiswa dalam mempelajari materi ini yaitu dengan menampilkan beberapa contoh dan gambar serta memberi tugas mencari paper di internet sehingga akan memperkaya wawasan mereka.

\subsection{Parameter Sungai}

Ada beberapa parameter fisik palung sungai yang digunakan dalam hitungan hidrolika. Adalah penting untuk mengukur parameter fisik tersebut secara periodic dan telitiuntuk memahami perubahan yang terjadi di sungai. Parameter fisik tersebut adalah : 
a) Lebar puncak adalah lebar permukaan air melintang arah aliran.

b) Luas tampang basah.

c) Penampang melintang adalah penampang sungai tegak lurus arah aliran.

d) Thalweg adalah garis yang menghubungkan titik terendah palung sungai.

e) Kedalaman aliran (flowdepth) yaitu jarak antara dasar sungai dan muka air. Kedalaman diukur dari dasar palung terdalam (thalweg).

f) Kedalaman normal adalah kedalaman aliran pada saluran uniform.

g) Kemiringan dasar sungai .

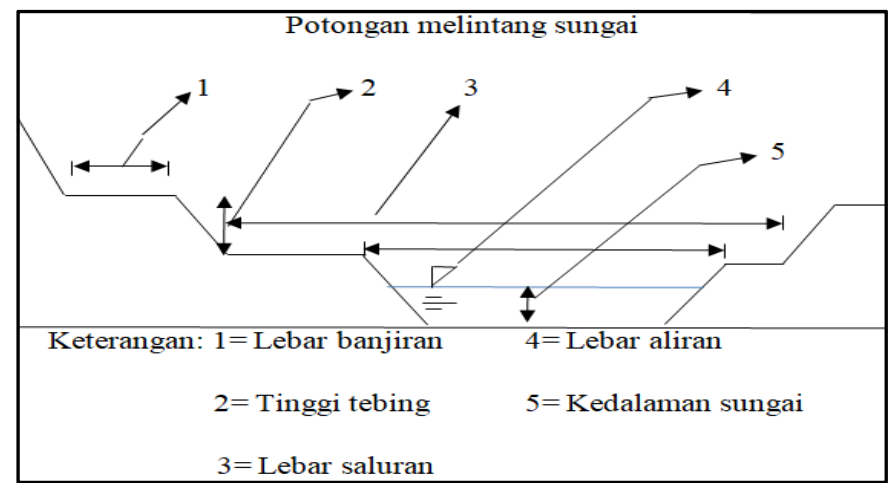

Gambar 11-1. Parameter fisik sungai

\subsection{Kedalaman Normal}

Kedalaman normal adalah aliran yang terjadi di saluran dengan tampang beraturan sehingga kemiringan muka air sama dengan kemiringan dasar saluran. Dalam aliran ini arah aliran 
saling sejajar sempurna tidak ada turbulensi dan arus balik (eddies). Di sungai hal ini sangat tergantung dari geometri palung sungai dan aliran ini dapat terjadi hanya pada ruas sungai yang lurus dengan tampang yang relative beraturan. Pada sungai yang bermeander penampang ini terjadi di lokasi 'crossing' (tempat berubahnya arah meander). Di tempat yang relative lurus dan beraturan ini terjadi aliran dengan kedalaman normal. Di tempat yang lurus ini (kira-kira panjangnya $20 \mathrm{x}$ lebar sungai) hubungan antara elevasi muka air dan debit $\mathrm{Q}$ adalah unik, artinya untuk satu nilai elevasi hanya terdapat satu nilai debit. Tempat yang bersifat unik ini dapat dipakai sebagai titik awal perhitungan elevasi muka air.

Terdapat beberapa parameter fisik palung sungai yang digunakan dalam hitungan hidrolika. Penting untuk mengukur parameter fisik tersebut secara periodik dan teliti untuk memahami perubahan yang terjadi di sungai. Adapun parameter fisik tersebut adalah lebar puncak adalah lebar permukaan air tegak lurus arah aliran, perimeter basah $\mathrm{p}$ adalah panjang keliling dasar dan tebing sungai mengikuti tampang melintang tegak lurus aliran, luas tampang basah adalah luas tampang melintang yang dibatasi oleh keliling dasar sungai dan muka air, tampang melintang (cross-section) adalah tampang sungai tegak lurus arah aliran, thalweg adalah garis yang menghubungkan titik terrendah palung sungai, kedalaman aliran (flow depth) yaitu jarak antara dasar sungai dan muka air, kedalaman diukur dari dasar palung terdalam (thalweg), kedalaman normal adalah 
kedalaman aliran pada saluran uniform dengan aliran steady flow. Pada kondisi ini muka air sejajar dengan kemiringan dasar saluran dan juga kemiringan energinya, kemiringan dasar memanjang adalah kemiringan rata-rata thalweg pada ruas sungai tertentu.

Kedalaman normal adalah aliran yang terjadi di saluran dengan tampang beraturan sehingga kemiringan muka air sama dengan kemiringan dasar saluran. Dalam aliran ini arah aliran saling sejajar sempurna tidak ada turbulensi dan arus balik (eddies).

\subsubsection{Bilangan Froude}

Bilangan Froude adalah angka nondimensional hubungan antara gaya inertia dan gaya gravitasi pada aliran air. Froude seorang ilmuwan Inggris mengamati bahwa hambatan sebuah perahu ketika ditarik dalam air, jumlah gelombang yang terjadi akan sama jika perbandingan kecepatan perahu terhadap akar panjang gelombangnya sama. Dalam hidrolika panjang gelombang adalah sama dengan kedalaman hidrolik.

Bilangan Froude

$$
F r=\frac{V}{\sqrt{g \cdot d}}
$$

dengan :

$$
\begin{aligned}
& \mathrm{V}=\operatorname{kecepatan} \text { aliran }(\mathrm{m} / \mathrm{det}) \\
& \mathrm{g}=\operatorname{gravitasi}\left(9.8 \mathrm{~m} / \mathrm{det}^{2}\right) \\
& \mathrm{d}=\operatorname{kedalaman} \text { aliran }(\mathrm{m})
\end{aligned}
$$


Jika $\mathrm{F}_{\mathrm{r}}<1$ gaya gravitasi lebih dominan dan alirannya adalah subkritik. Jika $F_{r}>1$ gaya inertia lebih dominan dan alirannya adalah superkritik.

Angka Foude digunakan untuk menentukan jenis aliran. Untuk aliran subkritik kondisi pembatas (boundary condition) ada di hilir sementara untuk superkritik kondisi pembatasnya ada di hulu dan pada saat $\mathrm{F}_{\mathrm{r}}=1$ jenis alirannya adalah kritik

Bilangan Froude adalah angka nondimensional hubungan antara gaya inertia dan gaya gravitasi pada aliran air. Dalam hidrolika panjang gelombang adalah sama dengan kedalaman hidrolik. Angka Foude digunakan untuk menentukan jenis aliran. Untuk aliran subkritik kondisi pembatas (boundary condition) ada di hilir sementara untuk superkritik kondisi pembatasnya ada di hulu dan pada saat $\mathrm{F}_{\mathrm{r}}=1$ jenis alirannya adalah kritik.

\subsubsection{Bilangan Reynold}

Bilangan Reynold adalah angka nondimensional hubungan antara gaya inertia dan gaya kekentalan digunakan untuk menentukan suatu aliran laminar atau turbulen. Osborne Reynold seorang ilmuwan Inggris abad 17 mengamati hambatan angin di sebuah percobaan terowong angin.

Inersia adalah hasil perkalian antara kecepatan dan radius hidrolik dibagi dengan kekentalan kinematik.

Jika $\mathrm{R}_{\mathrm{e}}>2000$ aliran turbulent, jika $\mathrm{R}_{\mathrm{e}}<500$ aliran laminar dan jika terletak antara 500-2000 aliran transisi. Angka Reynold digunakan dalam analisis angkutan sedimen. Dalam 
hal ini kecepatan menjadi kecepatan gesek (shear velocity) dan radius hidrolik menjadi diameter butiran dasar pembentuk alur.

$$
R_{e} \text { bed }=\frac{V_{*} D}{v}
$$

Dimana

$$
\begin{array}{rlrl}
\mathrm{V}_{*} & = & \text { kecepatan rata }-\mathrm{rata}(\mathrm{m} / \mathrm{dtk}) \\
\mathrm{D} & = & \text { diameter partikel }(\mathrm{m}) \\
v(\mathrm{nu}) & = & \text { kekentalan kinematik fluida } \\
& \left(\mathrm{m}^{2} / \mathrm{dtk}\right) \\
\rho & = \\
\mu & \text { rapat massa fluida }\left(\mathrm{kg} / \mathrm{m}^{3}\right) \\
& \text { kekentalan mutlak }(\mathrm{Pa} \text { dtk })
\end{array}
$$

Bilangan Reynold adalah angka nondimensional hubungan antara gaya inertia dan gaya kekentalan digunakan untuk menentukan suatu aliran laminar atau turbulen. Angka Reynold digunakan dalam analisis angkutan sedimen. Dalam hal ini kecepatan menjadi kecepatan gesek (shear velocity) dan radius hidrolik menjadi diameter butiran dasar pembentuk alur. 


\section{MODUL 12. Hukum Kontinuitas, Kekekalan Energi Dan Momentum}

1. Sasaran Pembelajaran

- Mahasiswa dapat mengetahui serta memahamihukum kontinuitas

- Mahasiswa memahamihukum kekelan energi

- Memahamihukum momentum

2. Kemampuan yang mahasiswa yang menjadi prasyarat Hidrolika, Hidrologi dan pengembangan sumber daya air.

3. Keterkaitan bahan pembelajaran dengan pokok bahasan lainnya sangat berkaitan dan merupakan satu kesatuan yang saling menunjang

4. Manfaat atau pentingnya bahan pembelajaran ini yaitu mahasiswa mampu memahami distribusi kecepatan, konservasi energi .

5. Petunjuk belajar mahasiswa, penjelasan tentang hal hal yang perlu dilakukan mahasiswa dalam mempelajari materi ini yaitu dengan menampilkan beberapa contoh dan gambar serta memberi tugas mencari paper di internet sehingga akan memperkaya wawasan mereka..

\subsection{Hukum Kontinuitas}

Saluran terbuka mempunyai permukaan yang terbuka terhadap atmosfer, padahal air adalah suatu zat yang tak bisa dimampatkan. Jadi pasti ketika air mengalir melalui sungai yang tampang melintangnya tidak beraturan aliran tersebut akan mengalami perubahan kecepatan dan kedalaman menyesuaikan terhadap bentuk geometri sungai. Jika tidak ada air yang masuk 
dan meninggalkan sungai, jumlah air yang mengalir akan tetap sama dari tiap tampang melintang sungai. Karena air tidak dapat dimampatkan maka hasil perkalian kecepatan aliran dan luas tampang melintang akan tetap sama.

Persamaan konservasi massanya adalah sbb :

$$
\mathrm{Q}=\mathrm{V} \cdot \mathrm{A}
$$

dengan :

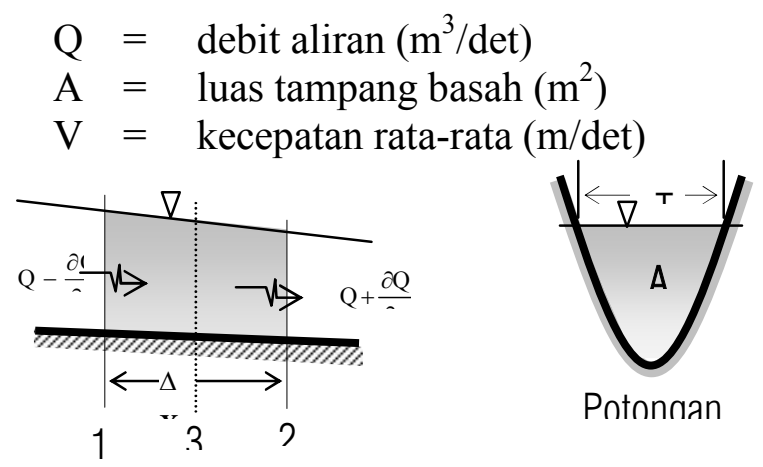

Gambar 12-1. Kontinuitas aliran dalam suatu pias

Prinsip kontinuitas menyatakan bahwa jumlah pertambahan volume sama dengan besarnya menghasilkan persamaan sebagai berikut :

$$
\mathbf{Q}=\text { konstan atau }
$$

$$
\mathrm{Q}_{1}=\mathrm{Q}_{2} \rightarrow \mathrm{A}_{1} \mathrm{~V}_{1}=\mathrm{A}_{2} \mathrm{~V}_{2}
$$

12.2 Aliran Permanen Seragam (Steady uniform flow)

Sifat aliran seragam yaitu mempunyai kecepatan konstan terhadap jarak, garis aliran lurus dan sejajar sehingga kecepatan adalah konstan terhadap waktu. Sehingga dapat dikatakan 
percepatan sama dengan nol, dan gaya-gaya yang bekerja pada pias air adalah dalam kondisi seimbang. Dengan demikian Hukum Kekekalan Energi dituliskan sebagai berikut :

$$
\mathrm{z}_{1}+\frac{\mathrm{p}_{1}}{\gamma}+\frac{\mathrm{v}_{1}^{2}}{2 \mathrm{~g}}=\mathrm{z}_{2}+\frac{\mathrm{p}_{2}}{\gamma}+\frac{\mathrm{v}_{2}^{2}}{2 \mathrm{~g}}+\mathrm{h}_{\mathrm{f}}
$$

Sehingga

$$
\mathrm{z}_{1}+\mathrm{h}_{1} \cos \theta+\frac{\mathrm{v}_{1}^{2}}{2 \mathrm{~g}}=\mathrm{z}_{2}+\mathrm{h}_{2} \operatorname{Cos} \theta+\frac{\mathrm{v}_{2}^{2}}{2 \mathrm{~g}}+\mathrm{h}_{\mathrm{f}}
$$

Umumnya saluran alamiah memiliki nilai $\theta$ sangat kecil, sehingga y $\operatorname{Cos} \theta=\mathrm{h}$, dengan demikian persamaan 7.12 menjadi:

$$
\mathrm{z}_{1}+\mathrm{h}_{1}+\frac{\mathrm{v}_{1}^{2}}{2 \mathrm{~g}}=\mathrm{z}_{2}+\mathrm{h}_{2}+\frac{\mathrm{v}_{2}^{2}}{2 \mathrm{~g}}+\mathrm{h}_{\mathrm{f}}
$$

kemiringan dasar saluran, muka air, dan gradien energi berturutturut adalah:

$$
\begin{gathered}
\mathrm{S}_{\mathrm{o}}=\operatorname{Sin} \theta=\frac{\left(\mathrm{z}_{1}-\mathrm{z}_{2}\right)}{\Delta \mathrm{L}} \\
\mathrm{S}_{\mathrm{w}}=\frac{\left(\mathrm{z}_{1}+\mathrm{h}_{1}\right)-\left(\mathrm{z}_{2}+\mathrm{h}_{2}\right)}{\Delta \mathrm{L}} \\
\mathrm{S}_{\mathrm{f}}=\frac{\mathrm{h}_{\mathrm{f}}}{\Delta \mathrm{L}} \frac{\left(\mathrm{z}_{1}+\mathrm{h}_{1}+\frac{\mathrm{v}_{1}^{2}}{2 \mathrm{~g}}\right)-\left(\mathrm{z}_{2}+\mathrm{h}_{2}+\frac{\mathrm{v}_{2}^{2}}{2 \mathrm{~g}}\right)}{\Delta \mathrm{L}}
\end{gathered}
$$



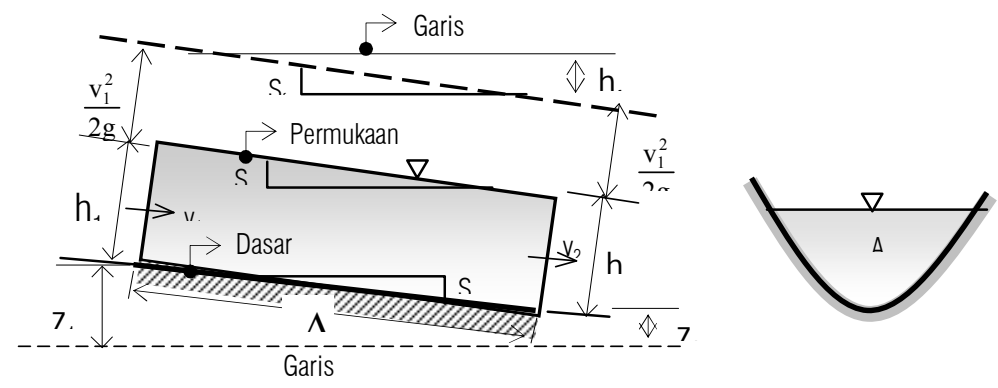

Gambar 12-2.Gaya-gaya pada aliran seragam

\subsection{Distribusi Kecepatan}

Distribusi kecepatan aliran biasanya sangat bervariasi dari satu titik ke titik lainnya di dalam saluran. Hal ini disebabkan adanya tegangan geser di dasar dan dinding saluran dan keberadaan permukaan bebas. Komponen kecepatan diperlihatkan dalam Gambar 12-3.

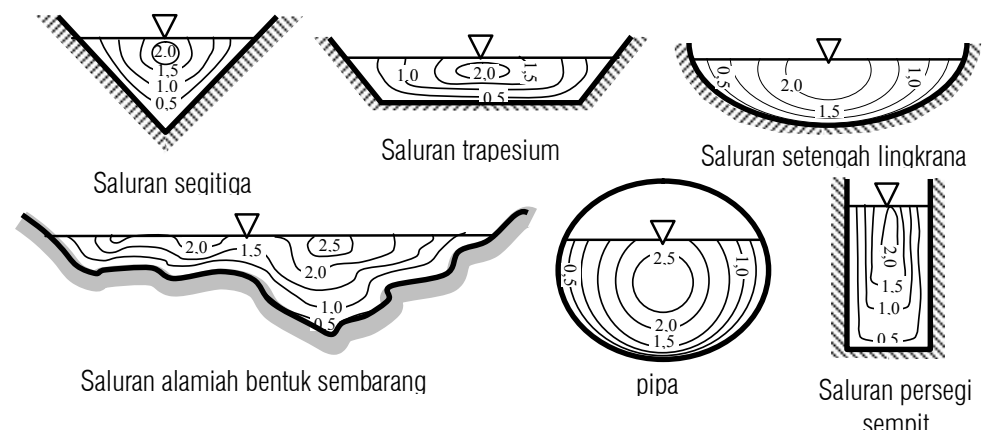

Gambar 12-3.Distribusi kecepatan pada berbagai bentuk potongan melintang saluran (Chow, 1959). 

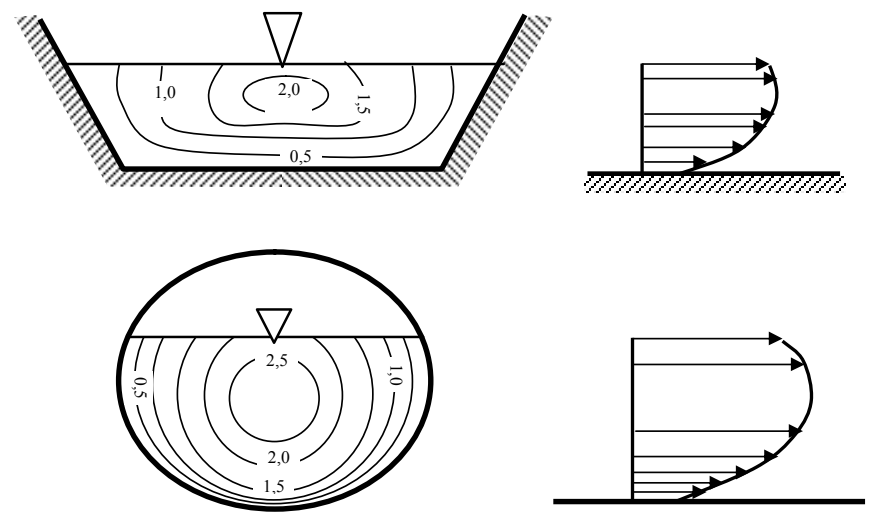

Gambar 12-4.Pola distribusi kecepatan sebagai fungsi kedalaman.

\subsection{Tegangan Geser dan Distribusi Kecepatan}

Tegangan geser $\tau$ adalah tegangan internal fluida yang melawan deformasi/perubahan bentuk. Tegangan geser lokal pada pertemuan antara bidang batas dan fluida dalam hal ini, tebal lapisan laminer dilambangkan dengan $\delta$ '. Dalam aliran laminer, tegangan geser pada bidang batas adalah:

$$
\tau_{\mathrm{o}}=\mu\left(\frac{\mathrm{dV}}{\mathrm{dh}}\right) \quad \text { pada } \mathrm{h}=0
$$

untuk $\mathrm{h}=z$, maka persamaan (7.17) menjadi

$$
\tau_{\mathrm{z}}=\mu\left(\frac{\mathrm{dV}}{\mathrm{dh}}\right)
$$




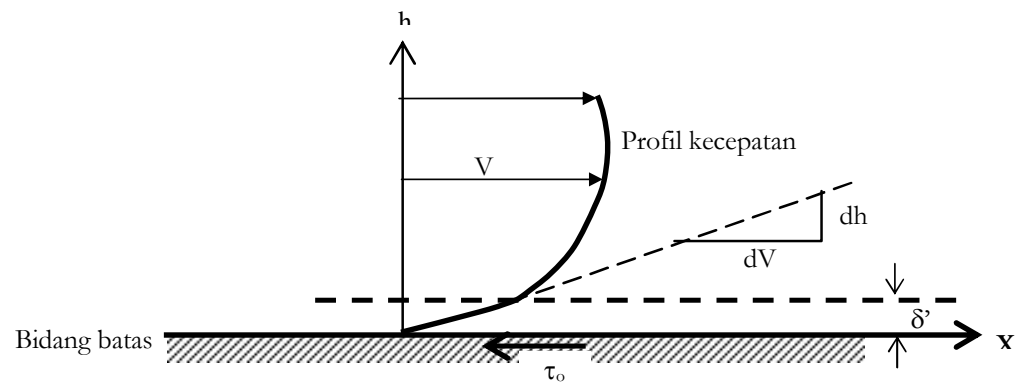

Gambar 12-5.Profil kecepatan pada bidang batas hidraulik halus

Pada aliran permanen beraturan, tegangan geser pada $\mathrm{h}=z$ adalah: :

$$
\tau_{\mathrm{z}}=\rho g(\mathrm{~h}-\mathrm{z}) \mathrm{S}_{\mathrm{f}}
$$

Untuk saluran sangat lebar $\mathrm{B}=\infty ; \mathrm{R}=\mathrm{h}$

$$
\begin{aligned}
& \mu \frac{d V_{z}}{d z}=\rho g(h-z) S_{f} \\
& V_{z}=\frac{g S_{f}}{v}\left(h z-\frac{1}{2} z^{2}+c\right)
\end{aligned}
$$

Syarat batas untuk z $=0$, maka $V_{z}=0$, jadi $c=0$.

Sehingga

$$
\mathrm{V}_{\mathrm{z}}=\frac{\mathrm{gS}_{\mathrm{f}}}{\mathrm{v}}\left(\mathrm{hz}-\frac{1}{2} \mathrm{z}^{2}\right)
$$

Debit persatuan lebar saluran $q, d q=V_{z} d z$ $q=\int \frac{g S_{f}}{v}\left(h z-\frac{1}{2} z^{2}\right) d z$ 


$$
\begin{aligned}
& \mathrm{q}=\frac{\mathrm{qS}}{\mathrm{v}}\left[\frac{1}{2} h \mathrm{z}^{2}-\frac{1}{6} \mathrm{z}^{3}\right]_{0}^{\mathrm{y}} \\
& \mathrm{q}=\frac{\mathrm{gS}_{\mathrm{f}} \mathrm{h}^{3}}{3 \mathrm{v}} \\
& \mathrm{V}=\frac{\mathrm{q}}{\mathrm{h}}
\end{aligned}
$$

sehingga :

$$
\overline{\mathrm{V}}=\frac{\mathrm{gS}_{\mathrm{f}}}{3 \mathrm{v}} \mathrm{y}^{2}
$$

untuk saluran sangat lebar

$$
\text { Atau } \overline{\mathrm{V}}=\frac{\mathrm{gS}_{\mathrm{f}}}{3 \mathrm{v}} \mathrm{R}^{2}
$$

untuk bentuk sembarang

\subsection{Sifat-sifat aliran Kritis}

Sifat aliran kritis dapat ditinjau pada potongan melintang yang paling sederhana, yaitu berbentuk persegi, kemuadian dikembangkan ke bentuk umum.

Energi spesifik untuk saluran persegi adalah:

$$
\mathrm{E}=\mathrm{h}+\frac{\mathrm{q}^{2}}{2 \mathrm{gh}^{2}}
$$

Secara matematis diketahui bahwa $d E / h y=0$ harga $E$ akan maksimum atau minimum. Sehingga, dengan mendeferensialkan persamaan 12.13 diperoleh:

$$
\frac{\mathrm{dE}}{\mathrm{dh}}=1-\frac{\mathrm{q}^{2}}{\mathrm{gh}^{3}}=0
$$


Jika kedalaman minimum dikatakan kedalaman kritis, $h_{\mathrm{c}}$. Dari persamaan 12.14 dapat diturunkan persamaan untuk menghitung kedalaman kritis sebagai berikut:

$$
\mathrm{h}_{\mathrm{c}}=\sqrt[3]{\frac{\mathrm{q}^{2}}{\mathrm{~g}}}
$$

Jika $V_{c}$ aliran kritis, dapat ditulis sebagai:

$$
\frac{\mathrm{V}_{\mathrm{c}}^{2}}{2 \mathrm{~g}}=\frac{1}{2} \mathrm{~h}_{\mathrm{c}}
$$

Sehingga aliran kritis sama dengan setengah kedalaman kritis diperoleh:

$$
\mathrm{E}_{\min }=\mathrm{h}_{\mathrm{c}}+\frac{1}{2} \mathrm{~h}_{\mathrm{c}}
$$

Atau

$$
\mathrm{h}_{\mathrm{c}}=\frac{2}{3} \mathrm{E}_{\min }
$$

kedalaman kritis sama dapat juga ditulis dalam bentuk:

$$
\frac{\mathrm{V}_{\mathrm{c}}^{2}}{\mathrm{gh}_{\mathrm{c}}}=1
$$

atau bilangan Froude adalah:

$$
\mathrm{F}_{\mathrm{r}}=\frac{\mathrm{V}_{\mathrm{c}}}{\sqrt{\mathrm{gy}_{\mathrm{c}}}}=1
$$

Persamaan ini menunjukkan bahwa bilangan Froude, $\mathrm{Fr}=1$, untuk aliran kritis. 


\section{MODUL 13. PENINGGIAN MUKA AIR DAN BENDUNG}

1. Sasaran Pembelajaran

- Mahasiswa dapat mengetahui serta memahamipemanfaatan air sugai.

2. Kemampuan yang mahasiswa yang menjadi prasyarat Hidrolika, Hidrologi dan pengembangan sumber daya air.

3. Keterkaitan bahan pembelajaran dengan pokok bahasan lainnya sangat berkaitan dan merupakan satu kesatuan yang saling menunjang

4. Manfaat atau pentingnya bahan pembelajaran ini yaitu mahasiswa mampu desain bendung, dan bangunan pelengkap bendung.

5. Petunjuk belajar mahasiswa, penjelasan tentang hal hal yang perlu dilakukan mahasiswa dalam mempelajari materi ini yaitu dengan menampilkan beberapa contoh dan gambar serta memberi tugas mencari paper di internet sehingga akan memperkaya wawasan mereka.

\subsection{Latar Belakang}

Konstruksi bangunan air di sungai adalah sebagai upaya meningkatkan faktor yang menguntungkan dan memperkecil atau menghilangkan faktor yang merugikan akibat tidak terkontrolnya sungai. Untuk itu bangunan persungaian bermanfaat untuk membantu manusia dalam kelangsungan hidupnya, dan memperbesar rasa aman dalam kehidupan manusia. Bangunan persungaian utama adalah :Waduk, Bendung, Stasion Pompa, dan Bangunan Pengambilan Bebas. 


\subsection{Pengertian dan Tujuan Bendung}

Bendung merupakan salah satu apa yang disebut dengan Diversion Hard Work yang berfiungsi meninggikan muka air. Konstruksi bendung umumnya terletak melintang memotong suatu aliran sungai. Konstruksi bendung membutuhkan analisis dan perhitungan yang detail dan menyeluruh. Syarat-syarat konstruksi bendung yaitu :

1) Konstruksi harus stabil dan mampu menahan tekanan air pada waktu banjir.

2) Memiliki daya dukung tanah di bawahnya.

3) Tidak bocoran (seepage) yang disebabkan oleh aliran air sungai dan aliran air yang meresap ke dalam tanah.

4) Ketinggian ambang bendung memiliki batas minimum yang diperlukan untuk seluruh daerah irigasi.

5) Konstruksi peluap harus mampu menahan gerusan dll.

Bangunan Utama adalah bangunan air (hydraulic structure) yang terdiri dari bagian-bagian: tubuh bendung , bangunan pengelak, bangunan intake, bangunan pembilas dan bangunan kantong lumpur.

\subsection{Pemilihan Lokasi Bendung}

Syarat pemilihan lokasi bendung harus mengacu pada posisi paling menguntungkan dari beberapa segi. Misalnya dilihat dari segi perencanaan, pengamanan bendung, 
pelaksanaan, pengoperasian, dan sebagainya. Dalam pemilihan lokasi perlu memperhatikan faktor-faktor antara lain :

- Pengaliran berlangsung secara gravitasi.

- Kestabilan bendung dengan memperhatikan batas maksimal 7 meter.

- Saluran primer berada pada trase yang mudah.

- Bangunan intake dapat menjamin kelancaran masuknya air.

- Lokasi bendung berada pada alur sungai yang lurus.

- Tidak menimbulkan pengempangan akibat aliran balik.

- Tanggul banjir serendah mungkin.

- Biaya konstruksi murah dan terjangkau.

\subsection{Pemilihan Tipe Bendung}

Konstruksi bendung disesuaikan kondisi sungai yang dibendung jika lokasi bendung menimbulkan pengaruh air balik dan berdampak pada daerah yang luas maka bendung gerak (bendung berpintu) merupakan pilihan yang tepat demikian pula sebaliknya dipilih bendung tetap. Jika sungai mengandung sedimen pada saat banjir, maka peredam energi yang sesuai adalah tipe kolam olakan (stilling basin). 


\section{1) Tipe Mercu Bendung pada Sungai}

Ada beberapa tipe mercu yang sering digunakan diantaranya : Tipe Mercu Bulat, Tipe Mercu Ogee dan Tipe Mercu Vlughter

\section{2) Bagian-Bagian Bendung}

a. Tubuh Bendung (Weir)

b. Pintu Air (Gates)

c. Pintu Penguras

d. Kolam Peredam Energi

- Kolam Olak Tipe Vlughter

- Kolam Olak Tipe Schoklitsch

- Kolam Olak Tipe Bucket

- Kolam Olak Tipe USBR

- Kolam Olak Tipe SAF = Saint Anthony Falls

e. Kantong Lumpur

f. Bangunan Pelengkap 


\section{MODUL 14. PERENCANAAN BENDUNG}

1. Sasaran Pembelajaran

- Mahasiswa dapat mengetahui serta memahami perencanaan bendung

2. Kemampuan yang mahasiswa yang menjadi prasyarat Hidrolika, Hidrologi dan pengembangan sumber daya air.

3. Keterkaitan bahan pembelajaran dengan pokok bahasan lainnya sangat berkaitan dan merupakan satu kesatuan yang saling menunjang

4. Manfaat atau pentingnya bahan pembelajaran ini yaitu mahasiswa mampu desain bendung, dan bangunan pelengkap bendung.

5. Petunjuk belajar mahasiswa, penjelasan tentang hal hal yang perlu dilakukan mahasiswa dalam mempelajari materi ini yaitu dengan menampilkan beberapa contoh dan gambar serta memberi tugas mencari paper di internet sehingga akan memperkaya wawasan mereka.

Perencanaan bendung mencakup keseluruhan struktur dan yang utama adalah konstruksi tubuh bendung yang terdiri dari: spilway, peredam energi, pondasi bendung dan lantai hulu bendung.

\subsection{Menentukan Elevasi Mercu Bendung.}

Elevasi mercu mengacu pada elevasi muka air yang di perlukan untuk irigasi (eksploitasi normal), Beda tinggi energi pada kantong lumpur untuk untuk membilas sedimen dari kantong, 
dan Beda tinggi energi yang di perlukan untuk meredam energi pada kolam olak.

Profil pelimpah atau mercu bendung diantaranya pelimpah profil bulat, pelimpah profil Bazin, pelimpah profil Modified Creager, dan masih banyak model mercu lainnya: Rumus debit melalui pelimpah :

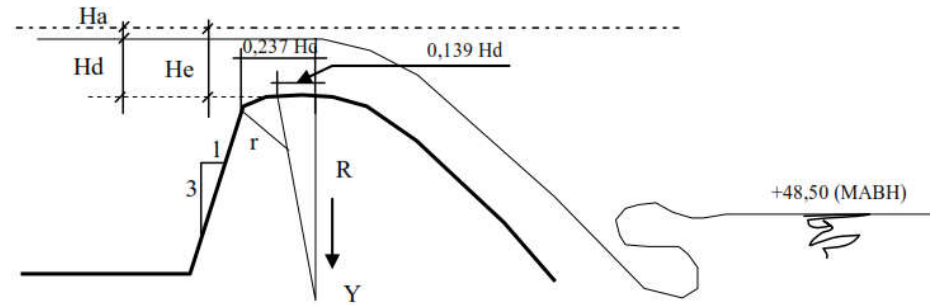

Gambar 8.3. Muka air di atas Mercu

$$
\mathrm{Q}=\mathrm{C}_{\mathrm{d}} 2 / 3 \sqrt{\frac{2}{3} \cdot \mathrm{g} \cdot} \cdot B e \cdot H e^{1,5}
$$

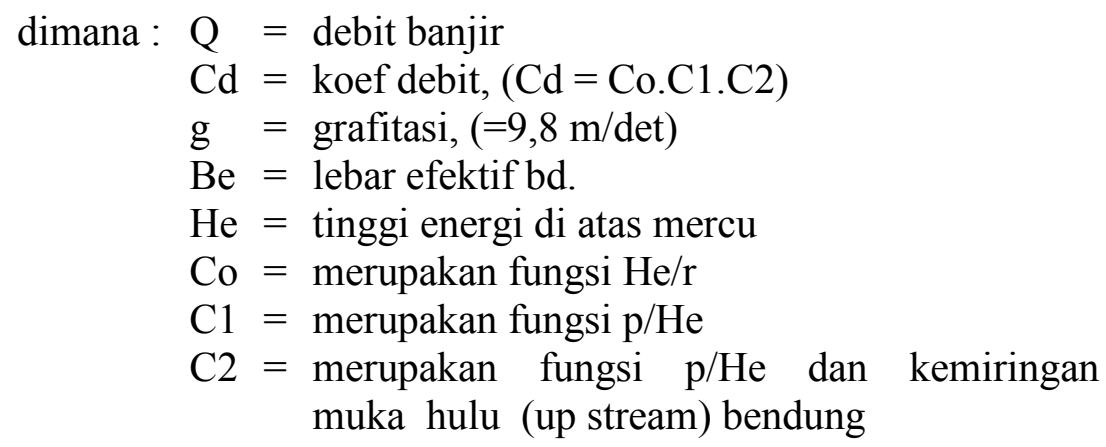

Bila disederhanakan rumus di atas menjadi :

$$
\mathrm{Q}=1,704 \cdot \mathrm{Be} \cdot \mathrm{He} \mathrm{e}^{1,5}
$$


Dari literatur lain (V.T. Chow) : Q = C.L.Be.He $\mathrm{e}^{1,5}$

Dimana $\mathrm{L}=\mathrm{Be}, \mathrm{C}$ mempunyai nilai 1,7 -2,2

14.2 Perhitungan Tinggi Air Banjir di hilir Bendung.

Perhitungan MAB harus dilakukan sebagai patokan dalam merencanakan kolam olakan (perendam energi) tujuannya agar diketahui berapa kedalaman lantai ruang olakan.

Adapun faktor utama yang harus di miliki adalah peta situasi sungai di sekitarbendung, yaitu $1 \mathrm{~km}$ ke udik dan $1 \mathrm{~km}$ ke hilir serta kearah kiri dan kanan sepanjang $0,50 \mathrm{~km}$ dari as rencana bendung. lihat gambar 8.1.

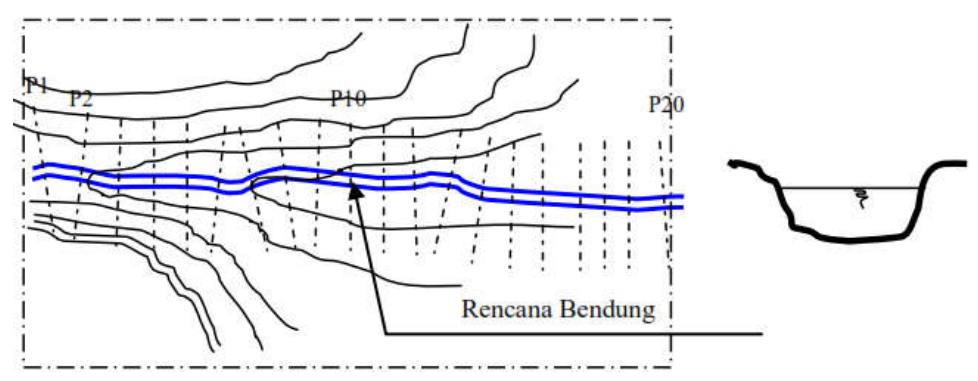

Gambar 14-1.Contoh lokasi dan potongan melintang sungai akan dibangun bangunan

Selain itu perlu diketahui keadaan sungai, tipe sungai, sedimentasi sungai dll. Profil memanjang di gunakan untuk mencari kemiringan rata-rata sungai. Kemiringan rata-rata di sekitar bendung yaitu :

$$
I_{\text {rata-rata }}=\sum_{i}^{j} I /\left(\begin{array}{ll}
n & 1
\end{array}\right)
$$


Profil melintang di gunakan untuk mencari luas tampang basah rata-rata sungai $\left(\mathrm{F}_{\text {rata-rata }}\right)$ Kemudian : $\mathrm{Q}=\mathrm{F} \times \mathrm{V}$

Dimana: $\quad \mathrm{Q}=$ debit sungai

$\mathrm{F}=$ luas tampang basah sungai

$\mathrm{V}=$ kecepatan aliran sungai

Untuk mencari $\mathrm{V}$ dapat di gunakan metode sbb :

Manning : $\quad V=\frac{1}{n} \cdot R^{2 / 3} \cdot I^{1 / 2}$

Dimana : $\quad \mathrm{n}=$ koefisien kekasaran Manning

$\mathrm{R}=$ jari-jari hidrolis

$\mathrm{I}=$ kemiringan rata-rata sungai

\subsection{Pintu Pengambilan (Intake)}

Fungsi dari pintu pengambilan adalah mengatur banyaknya air yang masuk saluran. Biasanya bendung, memiliki intake kanan dan kiri atau kadang hanya satu pintu intake tergantung dari letak daerah yang akan diairi. Berikut Gambar dan letak pintu pengambilan :
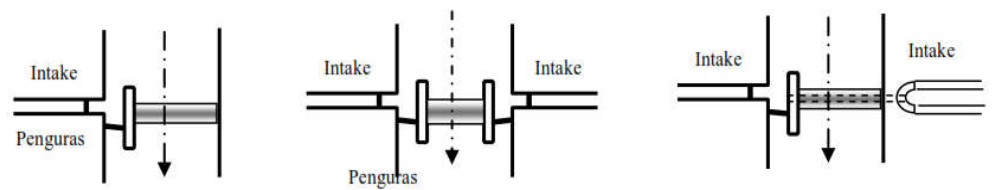

Gambar 14-2.Posisi intake 


\subsection{Penentuan Lebar Efektif Bendung}

Penentuan Lebar bendung ditentukan dengan jarak antara pangkal (abutment). Umumnya lebar bendung disesuaikan dengan lebar rata-rata sungai pada bagian yang lurus. Dalam perencanaan lebar total bendung diambil antara 1,0 - 1,2 dari lebar rata-rata sungai.Aliran dibatasi sampai sekitar 12 - 14 $\mathrm{m}^{3} /$ det/m' dan tinggi energy maksimum 3,5-4,5 m bertujuan agar konstruksi bangunan peredam energi tidak terlalu mahal.

Lebar efektif bendung :

$$
B e=B-2\left(n \cdot K_{p}+K a\right) H_{1}
$$

$$
\begin{aligned}
& \text { dengan: } \quad \mathrm{Be}=\text { lebar efektif bendung } \\
& \mathrm{B}=\text { lebar bendung. (lebar total-lebar pilar) } \\
& \mathrm{n}=\text { jumlah pilar } \\
& \mathrm{Kp}=\text { koef. kontraksi pilar } \\
& \mathrm{Ka}=\text { koef. kontraksi pangkal bd. } \\
& \mathrm{H}_{1}=\text { tinggi energi }
\end{aligned}
$$

Tabel 14-1. Nilai koefisien kontraksi pada Pilar:

\begin{tabular}{|l|c|}
\hline \multicolumn{1}{|c|}{ Pilar } & Kp \\
\hline Berujung segi empat dengan ujung yang dibulatkan dengan $\mathrm{r} \approx 0,1 \mathrm{t}$ & 0,002 \\
\hline Berujung bulat & 0,01 \\
\hline Berujung runcing & 0,00 \\
\hline \multicolumn{1}{|c|}{ Pangkal Tembok } & Ka \\
\hline Segi empat bersudut $90^{\circ}$ ke rah aliran & 0,20 \\
\hline Bulat bersudut $90^{\circ}$ ke rah aliran dengan $0,5 \mathrm{He}>\mathrm{r}>0,15 \mathrm{He}$ & 0,10 \\
\hline Bulat bersudut $45^{\circ}$ ke arah aliran dengan $\mathrm{r}>0,5 \mathrm{He}$ & 0,00 \\
\hline
\end{tabular}




\subsection{Perhitungan Kolam Olak/Peredam Energi}

Secara garis besar konstruksi peredam energi dibagi menjadi 4 (empat) tipe, yaitu :

$>$ Kolam Olak tipe Vlughter

$>$ Kolam Olak tipe Schoklitsch

$>$ Kolam Olak tipe Bucket

$>$ Kolam Olak tipe USBR

Pemilihan tipe peredam energi tergantung pada keadaan tanah dasar, perbedaan muka air hulu dan hilir dan sedimen pada aliran sungai.

\section{1) Kolam olak tipe Vlughter}

Kolam olak tipe Vlughter digunakan pada kondisi tanah aluvial dengan aliran sungai tidak membawa batuan besar. Bentuk hidrolis kolam ini akan dipengaruhi oleh tinggi energi di hulu di atas mercu (He), dan perbedaan energi di hulu dengan muka air banjir hilir (Z).Sebagai batasan tipe ini maka daam lantai olakan dari mercu bendung $\leq 8,00 \mathrm{~m}$ dan $\mathrm{Z} \leq 4,50 \mathrm{~m}$.

Perhitungan hidrolisnya sebagai berikut :

- $\quad$ Untuk $1 / 3 \leq \mathrm{Z} / \mathrm{He} \leq 4 / 3 \rightarrow \mathrm{D}=\mathrm{L}=\mathrm{R} 0,6=\mathrm{He}+$ $1,4 \mathrm{Z}$

$$
\rightarrow \mathrm{a}=0,20 \mathrm{He} \sqrt{\mathrm{He} / \mathrm{Z}}
$$

- $\quad$ Untuk $4 / 3 \leq \mathrm{Z} / \mathrm{He} \leq 10 \rightarrow \mathrm{D}=\mathrm{L}=\mathrm{R}=\mathrm{He}+1,1 \mathrm{Z}$

$$
\rightarrow \mathrm{a}=0,15 \mathrm{He} \sqrt{\mathrm{He} / \mathrm{Z}}
$$


Dimana $: \mathrm{D}=$ kedalaman kolam diukur dari puncak mercu sampai permukaan kolam

$\mathrm{L}=$ panjang kolam yang diukur dari perpotongan bidang miring dan horizontal

$\mathrm{R}=$ jari-jari kola

$\mathrm{a}=$ end sill

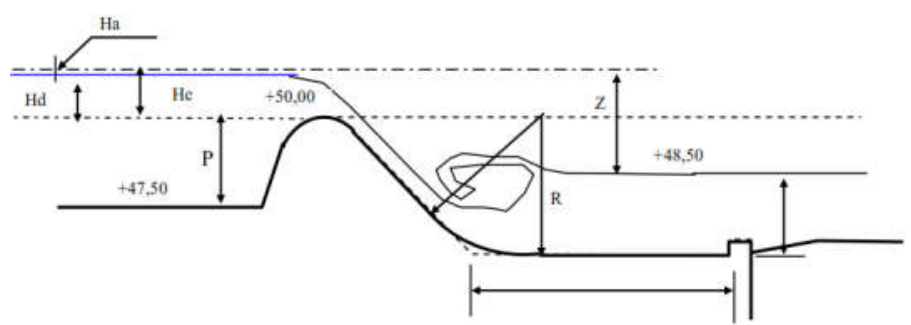

Gambar 14-3.Kolamolakan tipe Vlughter

\section{2) Kolam olak tipe Schoklitsch}

Kolam olak tipe Schoklitsch mempunyai bentuk hidrolis yang mirip dengan peredamenergi tipe Vlughter. Bentuk hidrolis kolam peredam energi inidipengaruhi oleh faktorfaktor :

- Tinggi energi di atas mercu

- Perbedaan tinggi energi di hulu dan muka air banjir di hilir (Z).

Perhitungan hidrolis :

Tipe ini adalah sama sifatnya dengan tipe Vlughter dan dipakai apabila pada tipe Vlughter besarnya D, L, R lebih besar dari atau sama dengan $8,00 \mathrm{~m}$, atau apabila $\mathrm{Z} \geq 4,50$ m. 


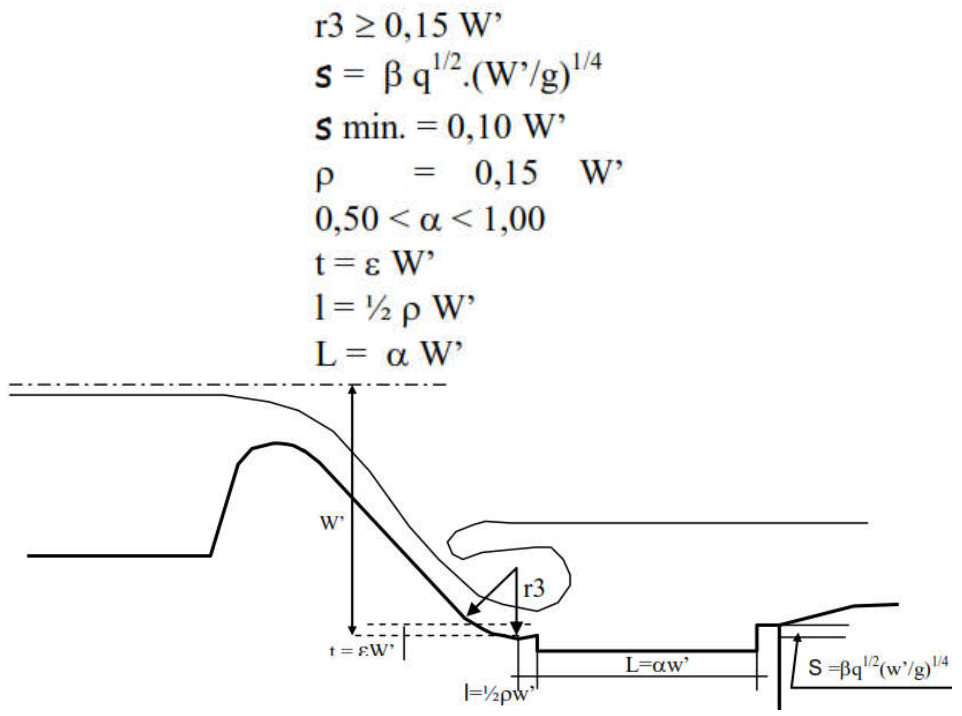

Gambar 14-4.Kolamolak tipe Schoklitsch

\section{3) Ruang olakan tipe Bucket}

Kolam peredam energi ini terdiri dari 3 tipe, yaitu :Solid bucket, Slotted Rooler bucket atau dentated Roller bucket dan Sky jump

Model peredam ini digunakan bilamana sungai membawa batuan boulder sehingga untuk menghindarkan kerusakan lantai belakang maka dibuat lantai yangmelengkung.

a.Solid bucket didesaian jika aliran membawa material batuan sebesar kelapa yang akanmenghancurkan lantai olakan.Bentuk hidrolisnya sbb :

$$
\begin{aligned}
& \mathrm{V} 1=\sqrt{2 \cdot g(H \quad H d)} \\
& \mathrm{R}=0,305 \cdot 10 \mathrm{p} \rightarrow(\mathrm{VT} . \text { Chow }) \\
& \mathrm{p}=(\mathrm{V} 1+6,4 \mathrm{Hd}+4,88) /(3,6 \mathrm{Hd}+19,5)
\end{aligned}
$$




$$
\mathrm{R}=0,6 \sqrt{H \cdot H d} \rightarrow \text { (Varshney) }
$$

Untuk menentukan elevasi dasar lantai peredam :

$\Delta \mathrm{H} / \mathrm{hc} \leq 2,4 \rightarrow \mathrm{Tmin} / \mathrm{hc}=1,88(\Delta \mathrm{H} / \mathrm{hc})^{0,215}$

$\Delta \mathrm{H} / \mathrm{hc}>2,4 \rightarrow \mathrm{Tmin} / \mathrm{hc}=1,7(\Delta \mathrm{H} / \mathrm{hc})^{0,33}$

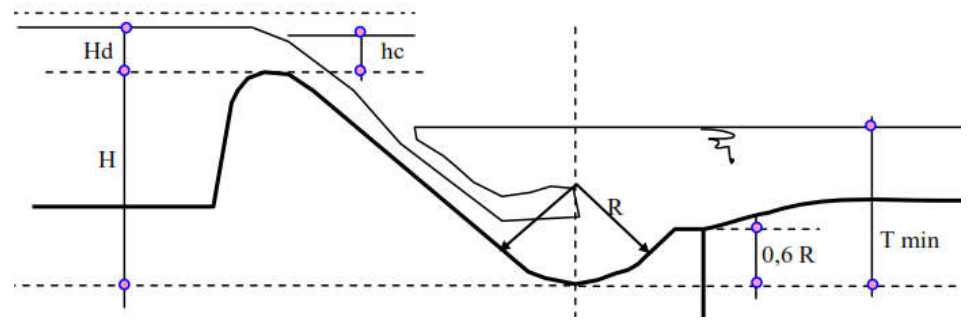

Gambar 14-5.Kolam olakan tipe Bucket

b.Sky Jump Bangunan ini dipilih jika keadaan loncata air sangat tinggi dan keadaan air dibelakang kolam kecil dan olakan ini akan lebih tahanterhadap terjangan banjir yang membawa batu-batuan.Perhitungan hidrolis Kolam olak Sky Jump :

$$
\begin{aligned}
& \mathrm{V} 1=\sqrt{2 \cdot g(H \quad 0,5 H d)} \\
& \mathrm{R}=0,305 \cdot 10 \rightarrow(\mathrm{VT} . \text { Chow }) \\
& \mathrm{R}=0,5 \cdot \sqrt{H \cdot H d} \\
& \mathrm{p}=(\mathrm{V} 1+6,4 \mathrm{Hd}+4,88) /(3,6 \mathrm{Hd}+19,5) \\
& \mathrm{R}=0,6 \sqrt{H \cdot H d} \rightarrow(\text { Varshney }) \\
& \sqrt{F 1}=0,09 \cdot \mathrm{R} / \mathrm{D}+1,95 \\
& \mathrm{~F} 1=13 \cdot \mathrm{R}^{1 / 2}-19,5
\end{aligned}
$$

Untuk jarak loncatan air (x) dan tinggi loncatan air terhadap lip (y) adalah :

$$
\begin{aligned}
& \mathrm{x}=(\mathrm{V} 2 \sin 2 \Phi) / \mathrm{g} \\
& \mathrm{y}=\mathrm{h} \sin 2 \Phi
\end{aligned}
$$




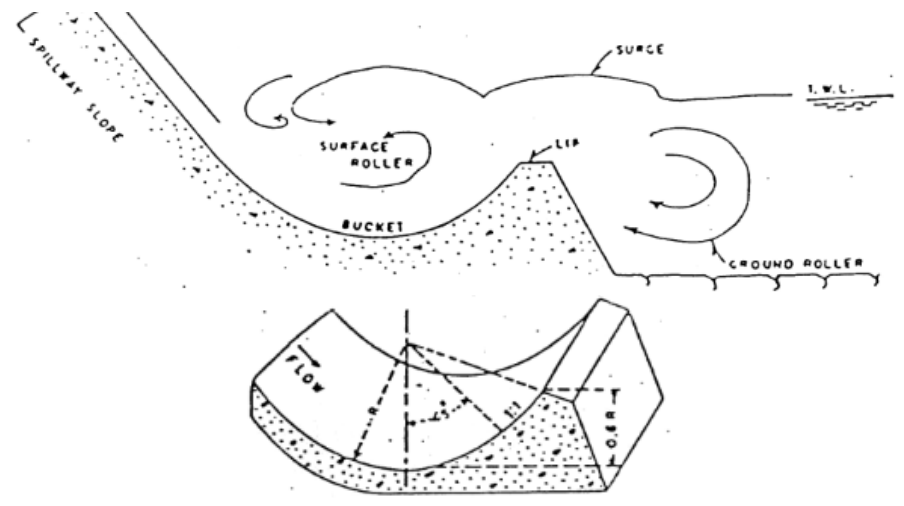

Gambar 14-6.Kolam olakan tipe Bucket

\section{4) Kolam olak tipe USBR}

Kolam olak tipe USBRdidesain untuk tinggi jatuh lebih tinggi dari 10 meter. Terdapat empat type USBR yangdibedakan hidraulik aliran dan konstruksinya.

a. Ruang olakan USBR I

b. Ruang olakan USBR II

- Cocok untuk aliran dg tekanan hidrostatis $>60 \mathrm{~m}$

- $\mathrm{Q}>45 \mathrm{~m}^{3} / \mathrm{det}$

- $\quad$ Bilangan Froud $>4,5$

c. Ruang olakan USBR III

- Cocok untuk mengalirkan air dg tekanan hidrostatis rendah

- $\mathrm{Q}<18,5 \mathrm{~m}^{3} / \mathrm{det}$

- $\mathrm{V}<18,0 \mathrm{~m} / \mathrm{det}$

- Bilangan Froud $>4,5$

d. Ruang olakan USBR VI 
- Cocok untuk mengalirkan air dg tekanan hidrostatis rendah

- $\quad$ Bilangan Froud antara 2,5 - 4,5

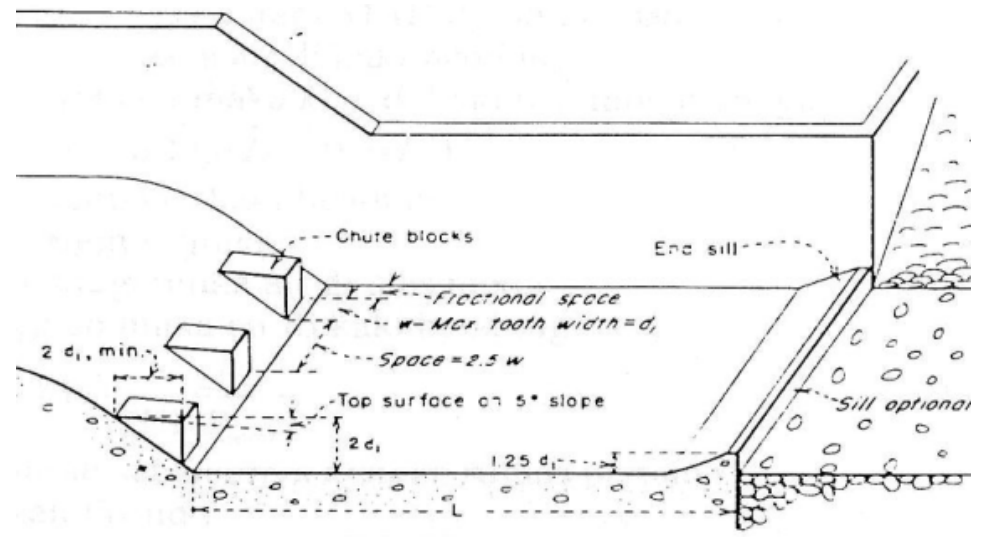

Gambar 14-7.Kolam olakan tipe USBR Type IV

Yang paling penting dalam perencanaan ruang olak tipe USBR adalah menghitung ratingjump dan tail water serta mencari bilangan Froud.

Langkah perhitungan :

1) Menghitung kec. Aliran di kaki bendung

$$
V=\sqrt{2 \cdot g \cdot\left(\begin{array}{ll}
H \quad Y 1
\end{array}\right)}
$$

dimana $: \mathrm{V}=$ kec. Aliran di kaki bendung

$\mathrm{H}=$ beda tinggi antara MAB dg dasar ruang olak

Y1 = tinggi muka air di kaki bendung

Karena Y1 belum diketahui maka kec. di kaki bendung dianggap sbb: 


$$
V 1=\sqrt{2 \cdot g \cdot(H \quad 0,5 H d)}
$$

Dimana : V1 $=$ kec. aliran di kaki bendung

$\mathrm{H}=$ tinggi terjunan

$\mathrm{Hd}=$ tinggi muka air di atas mercu

2) Menghitung ketinggian muka air di kaki bendung :

$$
Y 1=\frac{Q}{\left(V 1 . B_{\text {total }}\right)}
$$

3) Menghitung kec. aliran sebenarnya dengan rumus pertama.

4) Menghitung bilangan Froud: $F 1=\frac{V}{\sqrt{g \cdot Y 1}}$

5) Menghitung rating jump : $Y_{2} / Y_{1}=1 / 2\left(\sqrt{1+8 \cdot F^{2}}\right.$

6) Atau dengan menggunakan grafik hubungan antara F1 dengan $\mathrm{Y}_{2} / \mathrm{Y}_{1}$

7) Menghitungh tail water $\left(\mathrm{Y}_{2}^{\prime}\right)$ dengan menetapkan elevasi ruang olak sedemikian sehingga memenuhi syarat $\mathrm{Y}_{2}^{\prime}>\mathrm{Y}_{2}$.

8) Penentuan panjang ruang olak diperoleh dari gambar. Ketentuan lain dapat dilihat dari gambar menurut tipe masing-masing

\subsection{Analisis Stabilitas Bendung}

Analisis stabilitas bendung berdasarkan Gaya - gaya yang bekerja pada bangunan bendung dimana yang dianalisis yaitu :

a) Tekanan air : luar dan dalam, hidrostatik dan hidrodinamik. 
b) Tekanan lumpur : menekan horizontal dan membebani vertikal

c) Gaya gempa: tergantung peta gempa di Indonesia. Minimum 0,1g.

d) Berat sendiri bangunan : berat tubuh bendung.

e) Reaksi pondasi: gaya tekan ke atas terhadap bendung dari reaksi pondasi.

Stabilitas bendung harus stabil dalam 3 keadaan :

a) Kestabilan terhadap amblasnya bendung.

b) Kestabilan terhadap gelincir.

c) Kestabilan terhadap guling.

d) Kestabilan terhadap erosi bawah tanah bendung.

\section{Tekanan Air}

a) Gaya tekan air,terbagi atas gaya hidrostatik dan gaya hidrodinamik.

b) Gaya tekan ke atas, yaitu tekanan air dari dalam yang menyebabkan berkurangnyaberat efektif bangunan.

Dihitung dengan persamaan (berlaku bendung diatas batuan) berikut :

$$
\mathrm{W}_{\mathrm{u}}=\mathrm{c} \tau_{\mathrm{w}}\left[\mathrm{h}_{2}+\frac{1}{2} \xi\left(\mathrm{h}_{1}-\mathrm{h}_{2}\right)\right] A
$$

Dimana :

$\mathrm{C}=$ proporsi luas pada tekanan hidrostatik bekerja

$\tau \mathrm{w}=$ berat jenis air

h2 = kedalaman air hilir

$\xi \quad=$ proporsi tekanan (lihat tabel) 
h1 = kedalaman air hulu

$\mathrm{A} \quad=$ luas dasar $\mathrm{Wu}$

$\mathrm{W}_{\mathrm{u}} \quad$ = gaya tekan keatas.

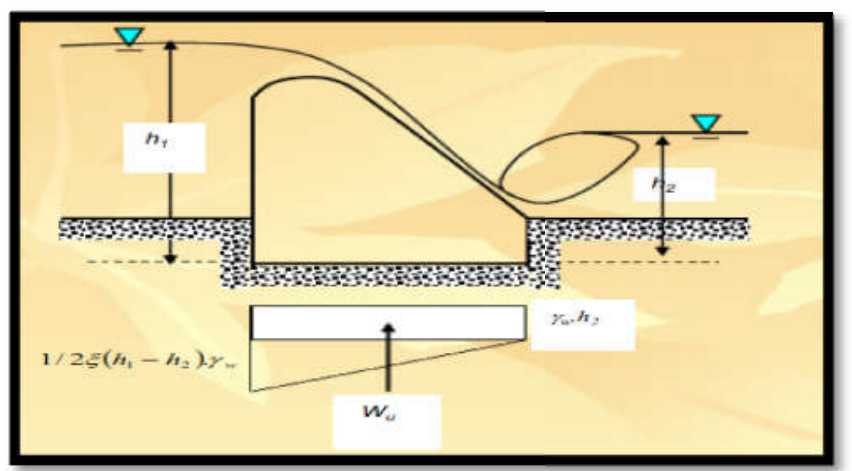

Gambar 14-9.Tekanan air pada bangunan bendung.

Tabel 14-2. Tipe pondasi batuan

\begin{tabular}{|c|c|}
\hline Tipe Pondasi Batuan & Nilai $\xi$ \\
\hline Berlapis Horizontal & 1 \\
\hline Sedang, pejal (massive) & 0,67 \\
\hline Baik, pejal & 0,5 \\
\hline
\end{tabular}

2. Tekanan Lumpur

$$
\begin{aligned}
& \mathrm{P}_{\mathrm{s}}=\frac{\tau_{\mathrm{s} . \mathrm{h}^{2}}}{2}\left(\frac{1-\sin \varphi}{1+\sin \varphi}\right) \\
& \tau_{\mathrm{s}}=\tau_{\mathrm{s}} \frac{, \mathrm{G}-1}{\mathrm{G}}
\end{aligned}
$$

dan untuk sudut gesek 30o digunakan :

$P_{s}=1,67 \cdot h^{2}$.

Dimana :

Ps = gaya pada $2 / 3$ kedalaman dari atas lumpur (horizontal)

$\mathrm{H} \quad=$ ketebalan lumpur

$\varphi \quad=$ sudut gesek 


$$
\begin{array}{ll}
\tau \mathbf{s} & =\text { berat lumpur } \\
\tau \mathbf{s}^{\prime} & =\text { berat volume kering } \\
\mathrm{G} & =\text { berat jenis tanah. }
\end{array}
$$

\section{Gaya Gempa}

a. Gaya gempa berdasarkan peta daerah gempa di Indonesia.

b. Harga percepatan (a), minimal 0,1 xpercepatan gravitasi.

c. Sebagai gaya horizontal nilai faktor tersebut dikalikan dengan berat bangunan.

Koefisien gempa dapat dihitung menggunakan rumus berikut :

$$
\begin{aligned}
& \mathrm{ad}=\mathrm{n}(\mathrm{ac} \times \mathrm{z})^{\mathrm{m}} \\
& \mathrm{E}=\frac{\mathrm{ad}}{\mathrm{g}}
\end{aligned}
$$

dimana :

$\mathrm{a}_{\mathrm{d}} \quad=$ percepatan gempa rencana, $\mathrm{cm} / \mathrm{dtk}^{2}$

$\mathrm{n}, \mathrm{m}=$ koefisien untuk jenis tanah; $\mathrm{a}_{\mathrm{c}}=$ percepatan kejut dasar, cm/dtk ${ }^{2}$

$\mathrm{E}=$ koefisien gempa; $\mathrm{G}=$ percepatan gravitasi, $\mathrm{cm} / \mathrm{dtk}^{2}(\cong 980)$

$\mathrm{Z} \quad$ = faktor yang bergantung kepada letak geografis (Koefisien Zona)

Tabel 14-3. Koefisien jenis tanah

\begin{tabular}{|c|c|c|}
\hline Jenis & N & M \\
\hline Batu & 2,76 & 0,71 \\
\hline Diluvium & 0,87 & 1,05 \\
\hline Aluvium & 1,56 & 0,89 \\
\hline Aluvium lunak & 0,29 & 1,32 \\
\hline
\end{tabular}


4. Berat sendiri

Besarnya berat sendiri konstruksi tergantung kepada bahan yang digunakan :
a) Pasangan batu
: $22 \mathrm{kN} / \mathrm{m}^{3}$
b) Beton tumbuk
: $23 \mathrm{kN} / \mathrm{m}^{3}$
c) Beton bertulang
: $24 \mathrm{kN} / \mathrm{m}^{3}$

5. Reaksi Pondasi

Reaksi pondasi sesuai denganbentuk bendung.

$$
\mathrm{P}=\frac{\sum(\mathrm{w})}{\mathrm{A}}+\frac{\sum(\mathrm{w}) \mathrm{e}}{\mathrm{I}}
$$

\section{Soal Latihan 7}

1. Uraikan tahapan penentuan jenis peredamenergy dan dalam kondisi apa jenis atau type digunakan?

2. Jika debit aliran sebesar $50 \mathrm{~m} 3 /$ det dan mengalir pada mercu dengan lebar $60 \mathrm{~m}$, berapakah ketinggian kritis aliran?

3. Jika mercu mengalami keruntuhan akibat terjangan banjir,uraikan pendapat saudara faktor-faktor yang dominan sebagai penyebab utama? 


\section{DAFTAR PUSTAKA}

1. Abdul Ghani. N. A. A., Othman. N., Baharudin. M.K.H., (2012). Study on Characteristics of Sediment and Sedimentation Rate at Sungai Lembing, Kuantan, Pahang, Precedia Engineering of Malaysian Technical Universities Conference on Engineering \& Technology 2012, MUCET 2012 Part 3 - Civil and Chemical Engineering.

2. Anasiru, T., (2006). Angkutan Sedimen Pada Muara Sungai Palu.

3. Asdak, C., (2002). Hidrologi dan Pengelolaan Daerah Aliran Sungai. University Press, Yogyakarta: UGM.

4. Bagnold, R.A., (1966). An Approach to Sediment10. Choudhury, P. and B. Sundar Sil, 2010. Integratedtransport problem from general physics. USwater and sediment flow simulation and forecastingGeological Survey Professional Paper, No, pp: $422-1$

https://www.researchgate.net/publication/313391614 Adjust ment of Bagnold's Suspended Sediment Formula [accessed Jan 16 2020].

5. Balai Sungai Pusat Penelitian dan Pengembangan Sumber Daya Air., (2017). Pelindung Tebing Sungai dengan Dump Stones. Balai Sungai. Surakarta.

6. Blanckaert, K., (2002). Analysis of Coherent Flow Structures in a BendBased on Instantaneous-Velocity Profiling, Third International Symposium on Ultrasonic Doppler Methods for Fluid MechaniCs and Fluid Engineering EPFL. Lausanne. Switzerland.

7. Booij R., (2003). Modeling the Flow in Curved Tidal Channels and Rivers.International Conference on Estuaries and Coasts, November 9-11. 2003. Hangzhou, China.

8. Brierley, G.J., Fryirs, K.A., (2005). Geomorphology and River Management: Application of the River Styles Framework. Blackwell Publications, Oxford, Inggris, Pp.398 
9. Chow V. T., Rosalina, N.N.V., Kristanto, S.V.F.X., Suyatman, (1989). Hidrolika Saluran Terbuka. Erlangga, Jakarta.

10. Cheng N., Chiew Y., (1999). Analysis of Initiation of Sediment Suspension from Bed Load. Journal of Hydraulic Eng. Vol 125, No. 8, pp 855-861, August, 1999.

11. Duan, J. G., (2004). Simulation of Flow and Mass Dispersion in Meandering Channels.Journal of Hidrolic Engineering@ASCE.

12. Einstein, H. A. (1950). The bed load function for sediment transportation in open channel flows, Tech. Bull. 1026, Soil Conserv. Serv., U.S. Dept. of Agric., Washington, D. C.

13. Erizal, (2013). Buku Ajar Hidraulika. http://web.ipb.ac.id/ erizal/hidrolika/

14. Graf, W. H., (1971). Hidrolics of Sediment Transport. Mc Graw-Hill Book Company. New York.

15. Humairah, Ayu Fajar, (2014). Analisis Hidrolika Bangunan Krib Permeabel pada Saluran Tanah (Uji Model Laboratorium). Jurnal Teknik Sipil dan Lingkungan. Vol 2 NoSeptember 2014.

16. Hoffmans, G.J.C.M. and Verhejj, (1997). Scour Manual, A.A. Balkema, Rotterdam.

17. Ishak, M. Galib, (2015). Coefficient of Superelevation for the Flow Using Movable Pillar in Channel Bend, Volume 7 Issue-1 No. 6 ISSN : 0975-4024, 63-69, http://www.enggjournals.com/ijet/docs/IJET15-07-01306.pdf

18. JR, Ray K. Linsley, (1996). Hidrologi untuk Insinyur. Erlangga Jakarta.

19. Kalinske, A.A., and Hsia, C.H., (1945). Study of transportation of fine sediment by flowing water: Bulletin No. 29, Iowa University Studies in Engineering, Iowa City, IA.

20. Kartini, (1995). Perhitungan Laju Sedimentasi Waduk Menggunakan Formula Leo Van Rijn (Studi Kasus Waduk 
Wonogiri). Proseding Pertemuan Ilmiah Tahunan (PIT) XII Himpunan Ahli Teknik Hidraulik Indonesia (HATHI) Surabaya 21-23 Nopember, Vol 1. Hal 187- 198.

21. Kirnoto, Bambang A., (1994). Hidrolies of Sediment Transport. Universitas Gajah Mada, Yogyakarta.

22. Kodoatie,Robert J., (1999). Sediment transport relations in Alluvial Channels, Ph.D. Disertation, Colorado State University, Co.,USA, 1999.

23. Kodoatie, R.J. dan Sugiyanto, (2002). Banjir (Beberapa Penyebab dan Metode Pengendalian Banjir dalam Perspektif Lingkungan), Pustaka Pelajar, Yogyakarta.

24. Kristijatno, Chr dan Kirno. Pelindung Tebing Sungai dengan Bangunan Krib Lulus Air. Puslitbang Pengairan.

25. Loebis, Joesron, (1987). Banjir Rencana untuk Bangunan Air, Badan Penerbit Pekerjaan Umum, Bandung.

26. Mananoma,T., Sudjarwadi, Raharjo,A.P., Legono, D., (2000). Analisis persamaan transport sedimen terhadap fenomena perubahan morfologi Sungai Progo tengah. Jurnal Teknik Sipil UGM.

27. Mardjikoen, P., (1993). Angkutan sedimen. Yogyakarta: UGM

28. Masjedi, A.,Kazemi, H., Foroushani, E. P., (2009). Experimental Study on the Effect of Cylindricad Bridge Pier Position on the Scoring Depth in the Rivers Bend, 33rd IAHR Congress: Water Engineering for a Sustainable Environment Copyright ${ }^{\circ} \mathrm{c} 2009$ by International Association of Hydraulic Engineering \& Research (IAHR) ISBN: 97894-90365-01-1.

29. Meyer-Peter, E., and R. Müller, (1948). Formulas for bed load transport, paper presented at 2nd Meeting, Int. Assoc. for Hydroaul. Environ. Eng. and Res., Madrid.

30. Mozaffari, J., Amiri-Tokaldany E., Blanckaert, (2011). Exprimental Investigations to Determine the Distribution of Longitudinal Velocity in Rivers Bends.Research Journal of Environmental Sciences 5 (6): 544, 2011 ISSN 1819-3412 / 
DOI:10,3923/rjes,2011,544,556 (C) 2011 Academic Journals Inc.

31. Nugroho, S., (2009). Respon morfometri dan penggunaan lahan DAS terhadap banjir bandang (Studi kasus bencana banjir bandang di Sungai Bohorok). Diambi kembali dari http://sirrma.bppt.go.id

32. Purnama, A., (2015). Konsentrasi Sedimen Suspensi pada Belokan $57^{\circ}$ Saluran Terbuka, Jurnal Unsa Progress. Vol.1, No.3, Oktober, Universitas Samawa, Sumbawa Besar.

33. Raju, Rangga, (1999). Aliran melaului saluran terbuka. Jakarta : Erlangga.

34. Roby Hambali, (2016). Studi Karakteristik Sedimen Dan Laju Sedimentasi Sungai Daeng - Kabupaten Bangka Barat, Jurnal Fropil Vol 4 Nomor 2 Juli-Des 2016.

35. Parker, G., Y. Shimizu, G. V. Wilkerson, E. C. Eke, J. D. Abad, J. W. Lauer, C. Paola, W. E. Dietrich, and V. R. Voller, (2011). A new framework for modeling the migration of meandering rivers, Earth Surf. Processes Landforms, 36(1), 70-86

36. Rosgen, D.L., (1994). A Classification of Natural Rivers. Catena, Vol. 22, 169-199. Elsevier Science, B.V. Amsterdam

37. Schumm S.A., (1979). Geomorphic Thresholds: The Concept and its Applications Professor of Geology, Colorado State University.

38. Simons, D.B., and Sentürk, F., (1977). Sediment transport technology: Water Resources Publications, Littleton, Colorado.

39. Suripin, (2004). Sistem Drainase Perkotaan yang Berkelanjutan, Yogyakarta: Penerbit ANDI

40. Soewarno J.L., Suprihadi B., (1993). Hidrologi Sungai”, Yayasan Badan Penerbit Pekerjaan Umum. 
41. Soekarno Indratmo, (1995). Bahan Kuliah Morphologi dan Hidrolika Sungai, Program Pasca Sarjana ITB Jurusan Teknik Sumber Air, Bandung.

42. Soewarno, (1991). Pengukuran Dan Pengelolaaan Data Aliran Sungai (Hidrometri). Nova. Bandung

43. Setyono, Ernawan, (2007). Krib Impermeabel Sebagai Pelindung pada Belokan Sungai. Universitas Muhammadiyah Malang. Malang

44. Raharjanto, (2007). Penerapan Kombinasi Dump Stones dan Bronjong untuk Pengamanan Tebing Sungai dan Prasarana Jalan. Teknologi Sumber Daya Air. Vol 4 No 2 Juni 2007.

45. Rijn, Leo. C. Van, (1992). Principles of Fluid flow and Surface Waves in Rivers, Estuaries, Seas, and Oceans. Aqua Publications.

46. Rouse, H., (1976). Hydraulics in the United States 17761976.Iowa Institute of Hydraulic Research, Iowa City, Iowa.

47. Sehyan, E., (1990). Dasar-Dasar Hidrologi. Yokyakarta. Gajah Mada University press.

48. Shibayama, T., Winyu, R., (1993). Vertical Distribution of Suspended Sediment Concentration in and Outside the Surf Zone. Coastal Engineering, in Japan, (36): 49-65.

49. Sosrodarsono, Suyono, (1994). Perbaikan dan Pengaturan Sungai. Jakarta: PT Pradya Paramita.

50. Subarkah, Iman, (1980). Bangunan Air, Idea Darma, Bandung.

51. Yang, C.T., (1996). Sediment Transport, Theory and Practice. Mc Graw Hill.New York.

52. Yen, C. L., Yen, B. C., (1971). Water Surface Configuration in Channel Bends. Journal of the HydrauliCs Division. Procedings of the American Sociaty of Civil Engineers.

53. Wiyono, A., Soekarno, I., Egon, A., (2006). Perbandingan Beberapa Formula Perhitungan Gerusan di Sekitar Pilar (Kajian Laboratorium). Jurnal Teknik Sipil ISSN 0853-2982 Vol. 13 No. 1. 


\section{TENTANG PENULIS}

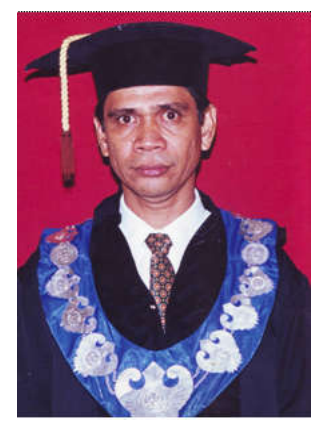

Muhammad Galib Ishak, lahir di Sengkang Kabupaten Wajo pada tanggal 3 September 1956, Sarjana Teknik Sipil Universitas Hasanuddin tahun 1983, Magister Teknik Sipil Institut Teknologi Bandung (Teknik Sumber Daya Air), Doktor Teknik Sipil Universitas Hasanuddin. Diangkat sebagai dosen pada Jurusan Teknik Sipil Fakultas Teknik Universitas Tadulako mulai tahun 1985 sampai sekarang. Pernah menjabat sebagai Ketua Jurusan Teknik Sipil, Direktur ADB No. 1253 Ino-Untad, Dekan Fakultas Teknik dan Ketua Lembaga Penelitian Universitas Tadulako.

Pernah bekerja di PLTA Bakaru sebagai supervisor In-situ Contruction Road Garugu-Bakaru, Setelah selesai pendidikan beberapa proyek yang pernah dikerjakan sebagai site manager antara lain; Proyek Irigasi Parigi Kanan, Pembangunan Jembatan Palu III, dan sebagai site engineer pada Proyek Irigasi Pesisir Barat Danau Poso.

Selain tugas utama sebagai dosen juga pernah ikut dalam organisasi yang berkaitan dengan jasa konstruksi antara lain; sebagai Wakil Ketua LPJK Sulawesi Tengah (2000-2004), Pengurus Persatuan Insinyur Indonesia Cabang Palu, dan Pengurus INKINDO Sulteng, Pengurus Himpunan Ahli Teknik Hidrolik Indonesia (HATHI) hingga sekarang.

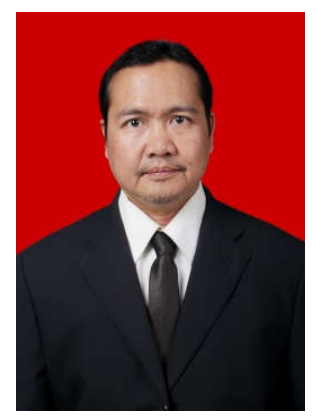

Rudi Herman, lahir di Ujungpandang, Kotamadya Makassar pada tanggal 21 Oktober 1971, Sarjana Teknik Sipil Universitas Hasanuddin tahun1996, Master of Science 2006 pada Program Euro Aquae Erasmus Mundus (Universite De Nice Sophia Anti-Polis) Bidang Hydro informatic and Water Management, Doktor Teknik Sipil Universitas Hasanuddin 2017. Diangkat sebagai dosen pada Jurusan Teknik Sipil Fakultas 
Teknik Universitas Tadulako mulai tahun 1997 sampai sekarang. Pernah menjabat sebaga Ketua Program Studi Teknik Sipil, dan Sekertaris Senat Fakultas Teknik Universitas Tadulako.

Mata kuliah yang diajarkan umumnya tentang Sipil Keairan, seperti Mekanika Fluida, Irigasi, Matematika Teknik, Rekayasa Sungai dan Hidrolika.

Pernah bekerja dalam beberapa proyek konsultan perencanaan di Sulawesi Tengah khususnya perencanaan PLTMH, SID Irigasi, perencanaan jaringan air bersih, perencanaan jaringan irigasi, perencanaan bendung serta peserta perencanaan supplai air bersih.

Selain tugas utama sebagai dosen juga pernah ikut dalam organisasi yang berkaitan dengan jasa konstruksi antara lain; Pengurus Himpunan Ahli Teknik Hidrolik Indonesia (HATHI) hingga sekarang. 